University of Louisville

ThinkIR: The University of Louisville's Institutional Repository

$12-2016$

\title{
Approaches to arthropod conservation : landscape genetics, community assessment, and prediction of extinction risk.
}

Victoria Annette Prescott

University of Louisville

Follow this and additional works at: https://ir.library.louisville.edu/etd

Part of the Biodiversity Commons

\section{Recommended Citation}

Prescott, Victoria Annette, "Approaches to arthropod conservation : landscape genetics, community assessment, and prediction of extinction risk." (2016). Electronic Theses and Dissertations. Paper 2588. https://doi.org/10.18297/etd/2588

This Doctoral Dissertation is brought to you for free and open access by ThinkIR: The University of Louisville's Institutional Repository. It has been accepted for inclusion in Electronic Theses and Dissertations by an authorized administrator of ThinkIR: The University of Louisville's Institutional Repository. This title appears here courtesy of the author, who has retained all other copyrights. For more information, please contact thinkir@louisville.edu. 
APROACHES TO ARTHROPOD CONSERVATION: LANDSCAPE GENETICS, COMMUNITY ASSESSMENT, AND PREDICTION OF EXTINCTION RISK

\author{
By \\ Victoria Annette Prescott \\ B.S., Baylor University, 2011

\begin{abstract}
A Dissertation
Submitted to the Faculty of the

College of Arts and Sciences of the University of Louisville in Partial Fulfillment of the Requirements

for the Degree of
\end{abstract}

Doctor of Philosophy in Biology

Department of Biology

University of Louisville

Louisville, Kentucky

December 2016 

APROACHES TO ARTHROPOD CONSERVATION: LANDSCAPE GENETICS, COMMUNITY ASSESSMENT, AND PREDICTION OF EXTINCTION RISK

\author{
By \\ Victoria Annette Prescott \\ B.S., Baylor University, 2011 \\ A Dissertation Approved on
}

October 28, 2016

by the following Dissertation Committee

\begin{tabular}{c}
\hline $\begin{array}{c}\text { Dissertation Director } \\
\text { Perri K. Eason }\end{array}$ \\
\hline James E. Alexander \\
\hline Gary Cobbs \\
\hline Robert B. Page \\
\hline Stephen P. Yanoviak
\end{tabular}




\section{DEDICATION}

To Dad 


\section{ACKNOWLEDGEMENTS}

I would like to thank my advisor, Dr. Perri Eason, for all of her amazing support. Words cannot express how thankful I am to you for not only all of your help, support, and encouragement, but also for letting me join your lab. I would also like to thank my dissertation committee, Dr. James Alexander, Dr. Gary Cobbs, Dr. Robert Page, and Dr. Stephen Yanoviak, for all of their constructive comments and support throughout my graduate career. Thank you to everyone who helped me collect spiders and survey dragonflies.

A very special thank you to my friends and family who have always been there for me. I would like to thank my parents for all of their love and support, even from across the country. A big thank you to my Uncle James and Aunt Diana for always feeding me at Thanksgiving. Margaritas have always been a big part of my life, and I would like to thank Sarah Fauque and Jennifer Guffey for always enjoying them with me. 


\begin{abstract}
APROACHES TO ARTHROPOD CONSERVATION: LANDSCAPE GENETICS, COMMUNITY ASSESSMENT, AND PREDICTION OF EXTINCTION RISK

Victoria A. Prescott
\end{abstract}

October 28, 2016

Although urbanization is a leading cause of species extinction throughout the world, the impact of urban development on arthropods is little studied and, as a result, poorly understood. I used three distinct approaches to studying arthropod conservation in North America. First, I used landscape genetics techniques to study the impact of urbanization on gene flow among populations of Rabidosa rabida, the rabid wolf spider. While gene flow was not detrimentally reduced, urban development correlated with a reduction in migration rates among populations, and to my knowledge, this is the first study to document isolation by resistance in spiders. Next, I examined how lentic and lotic odonate communities within the same landscape were affected by urbanization. Due to the inherent differences between lentic and lotic ecosystems and between dragonflies and damselflies, different environmental factors contributed to the persistence of particular species and thus to the makeup of adult odonate communities in urban areas. The different responses of dragonflies, damselflies, and spiders to urban development suggested that dispersal abilities strongly predict resilience to altered landscapes. Finally, I identified ecological correlates of an extinction risk assessment for North American 
odonates. Two of those correlates, geographic range size and length of flight period, are surrogate measures of dispersal. Both dragonfly and damselfly extinction risk assessments correlated with these two traits, but dragonfly assessments also correlated with the interactions between length of flight period and both geographic range size and habitat breadth. Collectively, this research showed that not all arthropods are negatively affected by urban development and that even closely related taxa are not always similarly affected. These differing responses were likely due to interspecific differences in dispersal abilities and life-history patterns, and possibly in odonates to taxonomic differences in flight capability and voltinism. These results highlight the need for further research on identifying the mechanisms driving urban biodiversity patterns and gaining a better understanding of the basic ecology of invertebrates. 
TABLE OF CONTENTS

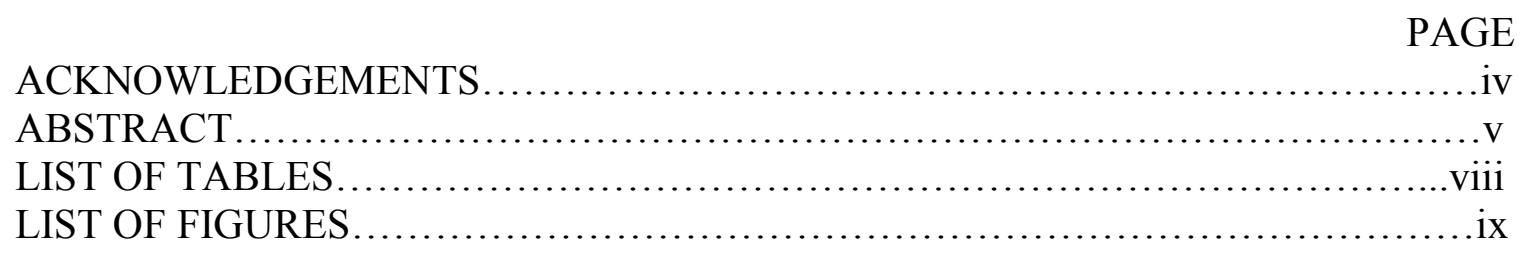

CHAPTER 1: INTRODUCTION TO THE DISSERTATION $\ldots \ldots \ldots \ldots \ldots \ldots \ldots \ldots \ldots \ldots \ldots$

CHAPTER 2: LANDSCAPE GENETICS OF RABIDOSA RABIDA ACROSS AN

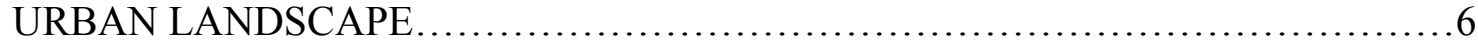

SUMMARY ............................................................6

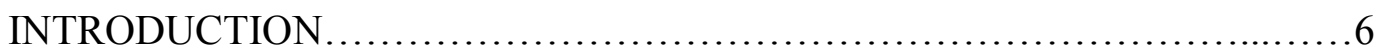

METHODS .............................................................. 10

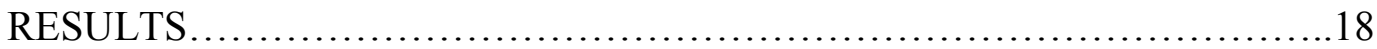

DISCUSSION ........................................................... 21

CHAPTER 3: URBANIZATION DIFFERENTLY AFFECTS POND AND STREAM

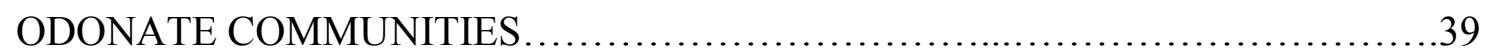

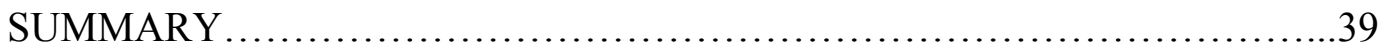

INTRODUCTION .....................................................40

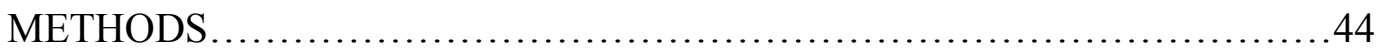

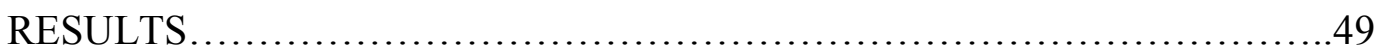

DISCUSSION .......................................................... 52

CHAPTER 4: DRAGONFLIES AND DAMSELFLIES HAVE DIFFERENT ECOLOGICAL CORRELATES WITH AN EXTINCTION RISK

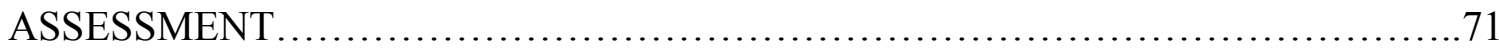

SUMMARY ............................................................. 71

INTRODUCTION .................................................... 72

METHODS ............................................................. 76

RESULTS......................................................... 80

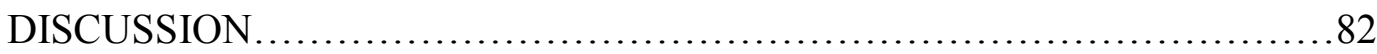

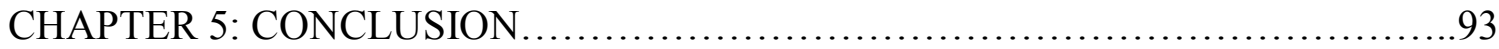

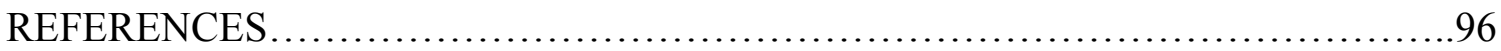


CURRICULUM VITAE........................................................ 


\section{LIST OF TABLES}

TABLE

PAGE

1. List of spider collection sites............................................ 26

2. Land cover classifications with habitat and resistance values.......................26

3. Summary statistics for each locus and mean values across loci....................27

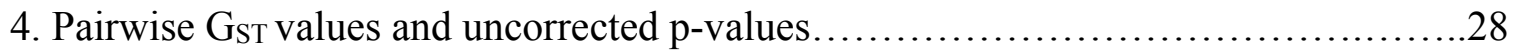

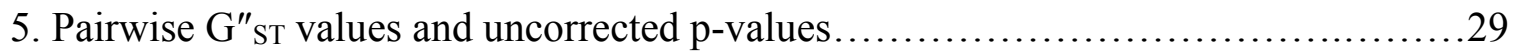

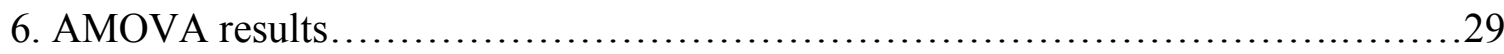

7. Historical migration rate estimates....................................... 30

8. Current migration rate estimates............................................. 31

9. Least-cost path lengths and effective resistances of linkages..................... 32

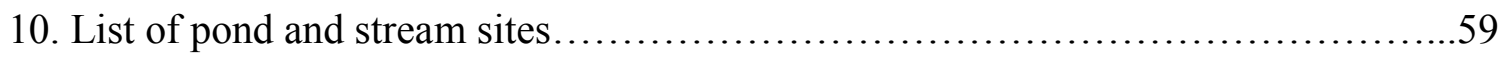

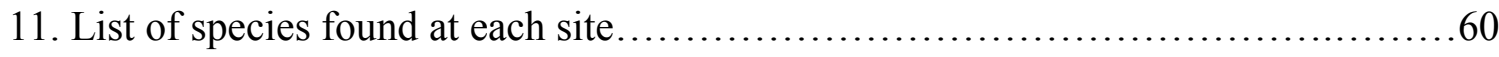

12. List of environmental variables and mean values.............................62

13. PERMANOVA results..................................................63

14. Canonical Correspondence Analyses results................................63

15. Indicator species analyses results.....................................64

16. List of aquatic ecosystems........................................... 88

17. Number of odonates in each conservation rank.............................. 88

18. Mean values of ecological traits for each conservation rank......................89

19. Ordinal logistic regression results...................................... 90

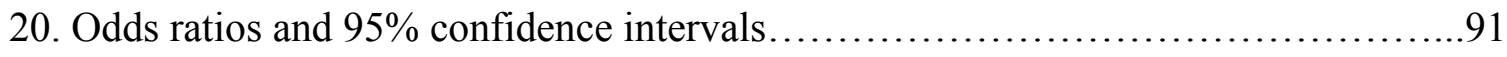




\section{LIST OF FIGURES}

FIGURE

PAGE

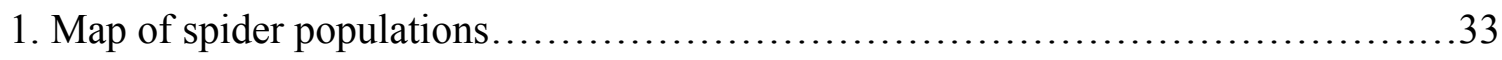

2. GENELAND posterior probabilities and genetic clusters.................... 34

3. GENELAND admixture..................................................

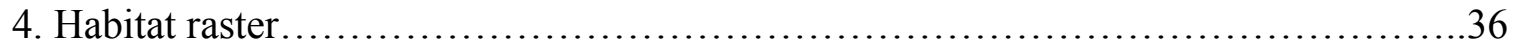

5. Least-cost paths..................................................... 37

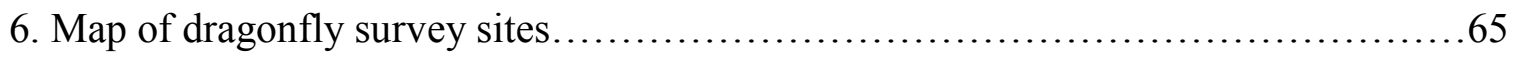

9. Odonate species richness..............................................66

8. Canonical correspondence analysis for ponds versus streams $\ldots \ldots \ldots \ldots \ldots \ldots \ldots \ldots .68$

9. Canonical correspondence analysis for urban versus rural ponds..................69

10. Canonical correspondence analysis for urban versus rural streams.................70

11. Prediction curve based on geographic range size $\ldots \ldots \ldots \ldots \ldots \ldots \ldots \ldots \ldots \ldots \ldots . \ldots . \ldots \ldots 2$

12. Prediction curve based on length of flight period............................92 


\section{CHAPTER 1}

\section{INTRODUCTION}

The world is currently suffering its sixth mass extinction (Barnosky et al. 2011), and this extinction event is unlike those of the past in that contemporary extinction rates are vastly higher. In previous extinction events, the extinction of $75 \%$ of species occurred over a period of 2 million years, but currently that same percentage of species will be lost in just 300 years (Barnosky et al. 2011), with an average of eight species lost each day (Cardoso et al. 2011a). The predominant drivers of today's mass extinction are habitat degradation and loss via anthropogenic causes (Leakey and Lewin 1995) such as deforestation, mining, agriculture, and urbanization, with urbanization being the leading cause (Vale and Vale 1976; Czech et al. 2000; Marzluff 2001; McDonald et al. 2008; Aronson et al. 2014). The amount of urban land cover is expected to expand by 1.2 million $\mathrm{km}^{2}$ between the years 2000 and 2030, which is a $185 \%$ increase over current land cover values (Seto et al. 2012).

Urbanization affects all aspects of both aquatic and terrestrial environments (Paul and Meyer 2001, Brönmark and Hansson 2002, Allan 2004, Foley et al. 2005; Grimm et al. 2008; Hassall 2014) and results in permanent land transformations (McKinney 2002, 2006). Habitat fragmentation (Fahrig 2003; Fuller et al. 2015; Haddad et al. 2015), exotic species (Gurevitch and Padilla 2004; Havel et al. 2015), and increased 
temperatures (Pickett et al. 2001; Grimm et al. 2008; Somers et al. 2013) are among the factors that most strongly affect ecosystems in urban areas. In addition, urbanization makes the landscape unsuitable for most species because it replaces native landscapes with novel and uniquely inhospitable ones (Unfried et al. 2013), and most native species cannot adapt to the altered and novel disturbance regimes that also occur in urban areas (Alberti 2005). Further, not only are important habitat patches degraded in quality, the corridors between those patches also become degraded (Verbeylen et al. 2003; Unfried et al. 2013).

A vast majority of conservation and wildlife studies focus on vertebrates (McIntyre 2000; Clark and May 2002; Cardoso et al. 2011a; Magle et al. 2012; D'Amen et al. 2013; Grodsky et al. 2015). As a result, our current understanding of how urban development affects invertebrates is poor even though arthropods alone make up half of the species on the planet (Redak 2000) and suffer a higher rate of extinction than do vertebrates (Cardoso et al. 2011a). Further, because conservation studies center on vertebrates, conservation management practices also cater to vertebrate conservation (Cardoso et al. 2011b, Barua et al. 2012) even though extinction patterns in vertebrates do not necessarily mirror those in invertebrates (Clausnitzer et al. 2009), and the needs of vertebrates drive the development and maintenance of nature reserves (D'Amen et al. 2013). The bias toward studying and conserving vertebrates is strong and clear. In North America alone, an estimated 200,000 species of insects and arachnids are believed to exist, yet only half are scientifically described (Redak 2000). This is a stark contrast from vertebrates, of which 45,000 species have been scientifically described and another 5,000 are estimated undescribed (Black et al. 2002). Additionally, only $0.5 \%$ of 
scientifically-described arthropod species have been assessed by the IUCN Red List compared to 42\% of vertebrates (Leather 2009; Cardoso et al. 2011b; D'Amen et al. 2013). While urbanization has been directly linked to insect extinction (Fattorini 2011), it is still unknown how other arthropods, such as spiders, respond to urbanization because only $10 \%$ of urban animal studies focused on arthropods (Magle et al. 2012).

Arthropods also provide numerous benefits to the planet. Arthropods provide a majority of ecosystem processes (Kim 1993, Redak 2000, Leather et al. 2008, Kotz et al. 2011), and because urbanization affects arthropods, ecosystem function is likely to also be affected (McIntyre 2000; McIntyre et al. 2001). For example, urbanization is leading to population declines of a variety of pollinators which will result in steep declines of plant diversity (Vanbergen 2013). Arthropods also provide numerous benefits to humans; despite a general negative perception of insects (Barua et al. 2012), they provide over $\$ 57$ billion in global revenue to the United States annually (Losey and Vaughn 2006). Finally, from a purely biological standpoint, arthropods, as with all other living creatures, have a right to exist even without conveying any sort of benefit to humans (Samways 2005).

In my dissertation, I take three distinct approaches to the study of arthropod conservation. In the first chapter, I use landscape genetic techniques to study the impact of urbanization on gene flow among populations of the wolf spider species Rabidosa rabida. Even with great advances in genetic analysis techniques and tools, very few studies have examined how urban land use affects the population genetics of arthropod species (Bond et al. 2006). Urbanization reduces gene flow in a variety of vertebrate species (e.g. lizards: Delaney et al. 2010; salamanders: Noël and Lapointe 2010; frogs: 
Hitchings and Beebee 1997, Mikulíček and Pišút 2012; birds: Delaney et al. 2010; Björklund et al. 2010, Unfried et al. 2013; and mammals: Epps et al. 2005, Lee et al. 2012, Munshi-South 2012, Santonastaso et al. 2012), but the results vary in arthropod studies. For example, conflicting results have emerged from studies on beetles, with one species being greatly affected (Keller and Largiadèr 2003) but others showing no effect of urbanization on gene flow (Desender et al. 2005). Additional studies are needed to gain insight into the responses of arthropods to urban development.

In my second chapter, I examined how urbanization alters dragonfly communities of both lentic and lotic ecosystems. Generally, vertebrate species richness tends to decrease with increasing urbanization (Ishitani et al. 2003; Urban et al. 2006; Pillsbury and Miller 2008; Van Nuland and Whitlow 2014; reviewed in McKinney 2008). Invertebrates exhibit a wide range of responses to urbanization despite the relatively low number of studies focused on this group. Invertebrate responses to urbanization often follow the vertebrate pattern, with species richness showing a consistent decline along rural to urban gradients (Hansen et al. 2005; reviewed by McKinney 2008). However, urbanization has neutral effects on invertebrate species richness in varied taxa (reviewed by Faeth et al. 2011; Jones and Leather 2012), and some studies found that invertebrate species richness increases in urban areas (Magura et al. 2004; Magura et al. 2010). Even though species richness may not always change due to urbanization, community composition consistently differs between urban and rural habitats in both vertebrates and invertebrates (Urban et al. 2006; Pillsbury and Miller 2008; Van Nuland and Whitlow 2014; reviewed in McKinney 2008). Urban animal communities typically have lower diversity than those in less altered habitats (McKinney 2002; Shochat et al. 2006; Luck 
and Smallbone 2010), and often widespread, non-native generalist species replace native species, resulting in homogenization at urban sites (McKinney and Lockwood 2001; Blair 2004; McKinney 2006; McDonnell and Hahs 2008; Horsák et al. 2013; Hassall 2014; Knop 2016; but see Olden and Rooney 2006).

In my third chapter, I identified three dragonfly traits that correlate with an extinction risk assessment. Population responses to changing habitats vary across odonates. Pantala flavescens, a dragonfly species that has a global migratory pattern, experiences gene flow on a global scale (Troast et al. 2016) while three damselfly species are somewhat negatively affected (Sato et al. 2008). These contrasting responses to urbanization may be due to species-specific biological and life-history traits that affect their resiliency to disturbance in the landscape (Prevedello and Vieira 2010), but comparative studies focusing on how ecological traits of arthropods correlate with extinction risk are largely unknown (McKinney 1997; Reynolds 2003; Hutchings et al. 2012; Jeppsson and Forslund 2014). The differences in the biological and life-history traits that frequently correlate with extinction risk (McKinney 1997; Reynolds 2003; Hutchings et al. 2012; Jeppsson and Forslund 2014) can be identified and used to assess which taxa are most at risk (Foufopoulos and Ives 1998). From there, conservation priorities can be established (Reynolds 2003; Jeppsson and Forslund 2014) and implemented (Nylin and Bergström 2009).

By investigating how arthropods are affected by urban land use and identifying ecological correlates with extinction risk, my dissertation provides insight into and future directions for the conservation of arthropods in North America. 


\section{CHAPTER II}

\section{LANDSCAPE GENETICS OF RABIDOSA RABIDA ACROSS AN URBAN}

\section{LANDSCAPE}

\section{SUMMARY}

Urbanization is a leading cause of habitat fragmentation and isolation because the urban matrix is typically of poor quality for most species and increases the resistance of the matrix to dispersal. This often reduces gene flow among populations. I used landscape genetic techniques to investigate the impact of urban development on gene flow among populations of the rabid wolf spider, Rabidosa rabida. Urbanization correlated with isolation by resistance and generally reduced migration rates among populations. However, the proportion of genetic variation among populations and estimates of genetic differentiation were low, and there were high degrees of admixture, suggesting that urban development does not drastically reduce gene flow among populations. Thus, urbanization does not greatly affect gene flow in this species. Two modes of dispersal, aerial and cursorial, likely maintain gene flow among populations.

\section{INTRODUCTION}

Anthropogenic land uses break up large swaths of continuous habitat into smaller patches that isolate animal populations. The degree of isolation is affected by several factors, including the number and features of traversable corridors linking habitat patches 
and the quality of the matrix surrounding those corridors (Ricketts 2001; Prugh et al. 2008; Prevedello and Vieira 2010). Populations become increasingly isolated when corridors are narrow (Andreassen et al. 1996) or composed of degraded habitat (Anderson and Danielson 1997; Henein and Merriam 1990). Isolation also increases when habitat patches are distant from one another and long corridors are required to promote connectivity. The quality of the matrix is determined by its similarity to occupied patches of habitat. The matrix habitat can be a primary determinant of population connectivity, with the matrix becoming increasingly inhospitable for native species as its characteristics diverge from inhabited areas (Öckinger and Smith 2008; Prevedello and Vieira 2010).

Habitat fragmentation and isolation caused by urbanization is of particular interest to conservation biologists because urbanization is the leading driver of species extinction (Czech et al. 2000; McKinney 2006) and is expected to continue to rapidly spread across the world (Alig et al. 2004; UN 2014). The urban matrix is typically of very poor quality for most species because it replaces native habitat (Unfried et al. 2013) with landscapes that typically lack or are very low in basic requirements for survival, such as appropriate food resources. In addition to making survival more difficult, urban development also increases the resistance of the matrix, thereby making animal dispersal more difficult and reducing gene flow among populations (Verbeylen et al. 2003; Unfried et al. 2013). Isolated populations have reduced genetic diversity and increased genetic differentiation due to forces such as inbreeding and genetic drift. When genetic variability is reduced, populations may suffer from lower survival and fitness (Reed and Frankham 2003) and may be unable to adequately respond to sudden changes in the environment (Hedrick 
2011). This is especially problematic in urban areas where natural disturbance regimes are altered and novel disturbances are introduced (Alberti 2005).

Most studies that investigate the effect of isolation on gene flow among populations use an isolation-by-distance framework (McRae 2006), which assumes the genetic difference between pairs of populations positively correlates with the geographic distances separating them (Wright 1943; Rousset 1997). However, using only the straight-line distance between populations ignores the heterogeneity of the matrix (Verbeylen et al. 2003) and may be particularly unsuitable for urban population genetics studies because of the intense resistance of the urban matrix to movement (Verbeylen et al. 2003). Including analyses assessing the quality of the corridors, which has been little studied in urban areas (Braaker et al. 2014), and landscape resistance results in a more indepth understanding of how urbanization affects animal populations. Isolation by resistance assesses the relationship between genetic differentiation among populations and the resistance of the landscape to migration based on electrical circuit theory (McRae 2006), with differentiation expected to increase with increasing resistance. In urban areas, corridors are likely to be highly degraded, resulting in greater genetic differentiation among populations than in less disturbed areas.

Surprisingly few studies have examined how urbanization affects population genetic dynamics in animals (Noël and Lapointe 2010), and those that have usually focused on genetic differentiation among urban populations as a function of geographic distance. Furthermore, among these studies, most have focused on vertebrate taxa (e.g. salamanders: Noël and Lapointe 2010; frogs: Hitchings and Beebee 1997, Mikulíček and Pišút 2012; lizards: Delaney et al. 2010; birds: Delaney et al. 2010; Björklund et al. 
2010, Unfried et al. 2013; and mammals: Epps et al. 2005, Lee et al. 2012, MunshiSouth 2012, Santonastaso et al. 2012). The general pattern emerging from these studies is that vertebrate populations in urban areas experience a reduction in gene flow.

How urbanization affects the population genetics of arthropods is not well understood (Bond et al. 2006). Studies of invertebrates have focused predominately on insects, especially those with strong flying capabilities, such as butterflies (Kronfrost and Fleming 2001; Takami et al. 2004), bees (Jha and Kremen 2013), and damselflies (Watts et al. 2004). These studies suggest that urbanization reduces gene flow among volant species (but see Kronfrost and Fleming 2001). To my knowledge, the only study to have tested for isolation by resistance in arthropods was done on bees (Jha and Kremen 2013). Studies on beetles, which are typically less mobile, have yielded conflicting results, with urbanization greatly reducing gene flow in one species (Keller and Largiadèr 2003) but not reducing it in others (Desender et al. 2005). The effects of anthropogenic landscapes on gene flow in spiders have not been well studied (e.g., Schäfer et al. 2001; Stefani and Del-Claro 2015, Bond et al. 2006), and no study has investigated isolation by resistance in this taxon.

Corridor quality and barriers in urban areas affect most ground-dwelling vertebrates and invertebrates (Vandergast et al. 2009; Braaker et al. 2014, Unfried et al. 2013). However, spiders may respond differently to a hostile, urban matrix because responses to matrix type are species-specific (Prevedello and Vieira 2010) and spiders are not strictly ground-dwelling. The genetic studies that have examined the impact of urbanization on spiders have shown that the effects vary with species. For example, Stefani and Del-Carlo (2015) found no detectable levels of genetic differentiation 
between urban and rural populations of funnel-web spiders, while Bond et al. (2006) found that urbanization resulted in the extinction of populations of different mygalomorph spider species through loss of adaptability associated with reductions in genetic diversity.

Wolf spiders are wandering predators possessing two modes of dispersal that enable movement on different scales. First, wolf spiders move short distances terrestrially (Bonte et al. 2006). Second, wolf spiders disperse aerially via a behavior known as ballooning — which entails the release of silk threads that enables wind to pick up and carry the spider to a new location. Typically ballooning only takes place during the juvenile phase (Bell et al. 2005) and the spider largely does not control the outcome (Bonte et al. 2007). As such, using this method of dispersal within a highly resistant landscape could limit gene flow among populations because the probability of reaching a suitable patch may be low. Thus, wolf spiders may be at least partially dependent on landscape connectivity for movement and gene flow, as is the case with ground-dwelling mammals (Braaker et al. 2014). While relatively little is known about the molecular ecology of wolf spiders, Reed et al. (2011) examined gene flow in Rabidosa rabida across fragmented patches in Mississippi and found significant levels of isolation by distance, suggesting that anthropogenic land use affects gene flow in this species. In this study, I investigated gene flow and isolation by resistance in $R$. rabida in the greater Louisville area in order to better understand how urbanization affects this species.

\section{METHODS}

Study Species 
Rabidosa rabida (Walckenaer 1837) is a wolf spider species that predominantly inhabits grasslands (Brady and McKinley 1994; Reed et al. 2007a), although this species can also be found in disturbed, suburban habitats. I chose to study $R$. rabida because it is abundant and easy to collect and genetic resources have been developed for this species (Reed et al. 2011). While the level of dispersal exhibited by this species is not well understood, Reed et al. (2011) suggested that aerial dispersal via ballooning is likely to be the predominant mode of dispersal for this species. With respect to terrestrial movement, lycosid spiders travel between $1 \mathrm{~m}$ (Framenau 2005) and $8 \mathrm{~m}$ (Bonte et al. 2003) per day.

Study Sites

From August through September 2013, I collected spiders from four urban and three rural sites in and around Louisville, Kentucky, with sites located within Interstate 265 classified as "urban" and those outside of I265 classified as "rural" (Figure 1, Table 1). I chose to use Interstate 265 as my delineation between urban and rural sites because it is a perimeter highway that surrounds the majority of the Louisville Metropolitan Area (population 763,623). The use of Interstate 265 as a delineation line between urban and rural sites is supported by the quantification of the amount of urbanization around each site, as all urban sites are surrounded by more than $45 \%$ urban land use while all rural sites are surrounded by less than $22 \%$ urban land use, as determined by the National Land Cover Database (Homer et al. 2015; Table 1). Distances between sites ranged from 6.94 $\mathrm{km}$ to $54.17 \mathrm{~km}$. 


\section{Collection Methods}

Between 15 and $28 R$. rabida were collected from each site. I collected spiders exclusively at night following the methods of Reed et al. (2007b). Specifically, I located spiders by scanning the ground and vegetation for their eyeshine in the light of a headlamp. Once captured, spiders were placed in labeled collection vials, and their GPS coordinates were recorded with a Garmin Dakota 10. Spiders were then taken to the lab where they were euthanized via freezing at $-20^{\circ} \mathrm{C}$.

\section{DNA Isolation and Genotyping}

DNA was isolated from each spider using a slight modification of the protocol described by Fetzner (1999). DNA isolates were used to genotype each spider at five microsatellite loci that were described by Reed et al. (2007a). I used the nested PCR approach described by Schuelke (2000) to label PCR products with 6-FAM. The forward or reverse primer for each locus was modified by appending a M13(-21) DNA sequence (TGT-AAA-ACG-GCC-AGT) to the 5' end of one of the primers in each respective primer pair based on the results of a hairpin analysis performed via the Integrated DNA Technology (IDT) website.

I amplified each locus with $25 \mu \mathrm{l}$ PCRs as follows: 1x buffer, $0.2 \mathrm{mM}$ dNTPs, 1.5 $\mathrm{mM} \mathrm{MgCl} 2,0.2 \mu \mathrm{M} \mathrm{M} 13(-21)-$ labeled species specific primer, $0.8 \mu \mathrm{M}$ untwinned primer, $0.8 \mu \mathrm{M}$ of M13(-21) labeled with 6-FAM , 0.625 units GoTaq DNA polymerase 
(Promega), 20-100ng DNA template. Reaction conditions were: $94^{\circ} \mathrm{C}$ for two minutes followed by 21 cycles of (1) $94^{\circ} \mathrm{C}$ for 30 seconds (2) $60^{\circ} \mathrm{C}$ for 30 seconds (3) $72^{\circ} \mathrm{C}$ for 40 seconds, followed by 8 additional cycles of (1) $94^{\circ} \mathrm{C}$ for 30 seconds (2) $53^{\circ} \mathrm{C}$ for 30 seconds (3) $72^{\circ} \mathrm{C}$ for 40 seconds and a final cleanup step of $72^{\circ} \mathrm{C}$ for 30 minutes. I shipped labeled PCR products to the Arizona State University DNA Lab where fragment analysis was performed using an ABI 3730. Scoring and binning were performed using GENEIOUS version 9.0.4 (Biomatters).

\section{Genetic Analysis}

I tested for deviations from Hardy-Weinberg equilibrium and pairwise genotypic disequilibrium using GenePop v4.2 (Rousset 2008) with 1000 dememorization steps, 100 batches, and 1000 iterations per batch. I then used GenAlEx (Peakall and Smouse 2012) to calculate $\mathrm{G}_{\mathrm{ST}}$ and $\mathrm{G}_{\text {ST }}$ (Meirmans and Hedrick 2011) and test for isolation by distance via a Mantel test. I also used GenAlEx to perform an analysis of molecular variance, AMOVA, (Excoffier et al. 1992) to determine how genetic variation is hierarchically partitioned among populations, among individuals within populations, and within individuals. All $P$-values were estimated from 9999 permutations, and when necessary, I corrected for multiple testing using Holm's (1979) procedure.

To determine whether urban development has reduced gene flow among populations, I used MIGRATE v3.6 (Beerli and Felsenstein 1999, 2001; Beerli 2009) and BAYESASS + v1.3 (Wilson and Rannala 2003) to compare current and historical levels of migration among populations, respectively. Both programs use Markov chain Monte 
Carlo algorithms to infer migration rates between populations; however MIGRATE estimates migration rates based on a coalescent model (Beerli and Felsenstein 1999) while BAYESASS+ uses transient linkage disequilibrium to estimate migration rates (Wilson and Rannala 2003). Although, MIGRATE is not the only population genetics software package to use a coalescent framework (e.g. Nath and Griffiths 1993, Slatkin and Maddison 1989), MIGRATE differs from other methods because it estimates migration rates from all possible genealogies and can be used under various mutation models and data types (Beerli and Felsenstein 1999). I ran MIGRATE under a Brownian motion model, using 1 long chain of 5,000,000 iterations, a burn-in period of 10,000 and 50,000 recorded steps. MIGRATE estimates the mutation-scaled migration rate $(M)$ $(M=\mathrm{m} / \mu$, where $\mathrm{m}=$ immigration rate, $\mu=$ mutation rate $)$ and the mutation-scaled effective population size $\left(\Theta=4 N_{e} \mu\right.$, where $N_{e}$ is the average effective population size over $4 N_{e}$ generations). Because MIGRATE and BAYESASS+ report similar but distinct parameters, I calculated $\mathrm{m}$ from the $M$ parameter estimated via MIGRATE by multiplying by a range of mutation rates that bracket empirical estimates from a variety of systems (Li et al. 2002).

BAYESASS + and other methods of estimating contemporary migration rates have fewer assumptions than estimators of historical migration rates (e.g. BAYESASS+ does not assume constant population size; Wilson and Rannala 2003). BAYESASS+ differs from other contemporary methods in that it does not assume that genotypes within a population are in Hardy-Weinberg equilibrium (Wilson and Rannala 2003). BAYESASS + estimates the migration rate of the last three generations (Wilson and Rannala 2003), and I ran this software with 3,000,000 iterations, a burn-in period of 
$1,000,000$, and a sampling number of 2,000. As recommended by Meirmans (2014), I used the model with the lowest Bayesian deviance.

\section{Landscape Analysis}

GENELAND (Guillot et al. 2005) is an R package that conducts spatially-explicit genetic clustering, and I used this software to gain insight into which landscape features within my study area that may be acting as barriers to gene flow among populations. I ran GENELAND with an uncertainty of $0.05 \mathrm{~m}$, a minimum of 1 population and a maximum of 7 populations, 100,000 iterations, and a thinning of 100 iterations. The allele frequency model option was set to correlated, the spatial model options was set to true, and the null allele model was set to true. I also tested for admixture with 20,000 iterations and a thinning of 10 .

To identify key barriers and corridors within the landscape, I implemented an array of software programs in ArcMap Student Edition 10.2 (ESRI 2015). I first created a $106 \mathrm{~km}$ by $88 \mathrm{~km}^{2}$ area that encompassed all sites, and then used the National Land Cover Database 2011 (Homer et al. 2015; NLCD) to classify the landscape characteristics within that area. The NLCD catalogs the earth's surface into 21 different land categories at a resolution of $30 \mathrm{~m}$. The NLCD describes four urban land use categories, which are based on the percentage of impervious surface within that $30 \mathrm{~m}$ resolution (Table 1). Within my buffer, I found 15 different land cover classifications (Table 2) 
In order to find corridors through the urban matrix and then determine the quality of these corridors, I quantified the amount of resistance found throughout the landscape. In addition to this, I also created habitat rasters to examine where the most suitable habitat within the landscape is located. To produce habitat and resistance rasters, I used Gnarly Landscape Utilities v0.1.0 (McRae et al. 2013a). To create the rasters, I gave habitat and resistance scores to each NLCD classification found in the landscape (Table 2). Habitat scores must range between zero and one, with one being the most suitable habitat (McRae et al. 2013a). The scores given are based on published papers and my knowledge of the biology of $R$. rabida. Because $R$. rabida is a grassland species, I gave the herbaceous classification a habitat value of one. While spiders can be found along the margins of forested areas that border meadow areas, they do not inhabit forested areas. Therefore, forested areas were given a habitat value of zero. The developed open intensity and developed low intensity land use classifications were given values of 0.8 and 0.7 , respectively, because $R$. rabida occurs in these types of habitat (personal observation).

Unlike habitat scores, resistance scores were not capped at a value of one (McRae et al. 2013a), and higher values were given to land uses that greatly impede dispersal. I reasoned that developed, high intensity land cover deserves a high resistance score because the tall grasses or shrubs that $R$. rabida requires are not found in commercial areas. As recommended by the creators of the software, the lowest resistance was 1 , which I assigned to the grassland category. This is necessary because Linkage Mapper v1.0 (McRae and Kavanagh 2011), which is used in the next step, cannot read resistance values of zero. For both types of rasters created, cells were not expanded. 
After creating the rasters, I implemented Linkage Mapper v1.0 to identify leastcost corridors between the sites. Linkage Mapper uses the resistance raster created in Gnarly Landscape Utilities to identify important corridors among sites. To obtain all pairwise resistance values, I unchecked Step 1, which only finds corridors (and subsequently resistance values) between adjacent populations. Next, I identified important barriers within those corridors using Barrier Mapper v1.0 (McRae 2012a). When using Barrier Mapper, I set the minimum search radius to $90 \mathrm{~m}$, the maximum radius to $270 \mathrm{~m}$, and the radius step value to $90 \mathrm{~m}$. This tells the software to search for barriers within the corridors at an initial radius of $90 \mathrm{~m}$, and then search again after increasing the radius by $90 \mathrm{~m}$ until the radius is $270 \mathrm{~m}$. The resolution of the resistance raster was $90 \mathrm{~m}$, which accordingly had to be the minimum radius. Gnarly Landscape Utilities established the resolution of the resistance raster as $90 \mathrm{~m}$, limiting the minimum search radius to $90 \mathrm{~m}$; Barrier Mapper only identified barriers at and above the resolution of the resistance raster (McRae 2012a).

Once this was done, I used Centrality Mapper v1.0 (McRae 2012b) to identify the most important corridors for maintaining connectivity between populations. Centrality Mapper does this by implementing Circuitscape v1.0 (McRae et al. 2013b) to send a one amp current across the corridors and core areas and then determining the current flow centrality. Next, I used Pinchpoint Mapper v1.0 (McRae 2012c) to identify areas within the corridors that are restricting movement. Like Centrality Mapper, Pinchpoint Mapper uses Circuitscape to send electrical currents through the corridors, but it then identifies specific areas within the corridors experiencing pinch points (bottlenecks). Circuitscape also calculates effective resistances between pairwise cores. To determine if isolation by 
resistance is present, I conducted a Mantel test on the $\mathrm{G}^{\prime \prime}$ sт pairwise values and the pairwise resistance values.

\section{RESULTS}

Genetic Analysis

After I corrected for multiple testing, three of the five loci tested in each of the seven sites (a total of 35 tests), deviated from Hardy-Weinberg equilibrium: locus 3 in Iroquois Park and locus 1 in Rural Sites B and C. We found no evidence for pair-wise genotypic disequilibrium between any pair of loci in any of the populations. Because no locus presented systemic problems across a majority of populations, I conducted my analyses using all five loci. Summary statistics for each population are presented in Table 3 .

Pairwise $G_{S T}$ values range from -0.003 to 0.019 (Table 4), and pairwise G"sT values range from -0.019 to 0.103 . After correcting for multiple testing, no comparisons were significant (Table 5). The global Gst, which provides the average $\mathrm{G}^{\prime \prime}$ sT value across all loci, was $0.009(p=0.014)$, and the global $G^{\prime \prime}$ st was $0.034(p=0.012)$. The AMOVA results presented in Table 6 show that differences among populations accounted for $4.3 \%$ of the variation in the data. The Mantel test provided no evidence of isolation by geographic distance $(\mathrm{r}=0.085, \mathrm{p}=0.388)$.

GENELAND detected three spatially explicit genetic clusters based on posterior probabilities (Figure 2). The posterior probabilities (Figure 2) indicate the likelihood that an individual belongs to a certain genetic cluster based on its geographic location. 
Spiders from the four urban sites grouped into two clusters and spiders from the three rural sites belong to a third cluster (Figure 2). With respect to the urban sites, GENELAND grouped the Iroquois Park and Thurman-Hutchins Park populations into one cluster and the E.P. "Tom" Sawyer Park and Blackacre State Nature Preserve populations into another cluster. Additionally, the analysis I performed in GENELAND indicated that all individuals were admixed (Figure 3), further underscoring that the populations I sampled were not well differentiated from one another. These results align with the posterior probabilities associated with cluster assignment, as no probabilities appeared above 0.60 , indicating that the assignment of each individual to its respective cluster was not particularly robust.

After assuming mutation rates to $1 \times 10^{-4}, 1 \times 10^{-5}$, and $1 \times 10^{-6}$ per generation per locus, MIGRATE estimated average proportions of migrants in each population as 6.463, 0.646 , and 0.065 . Mutation rates of $1 \times 10^{-4}$ and $1 \times 10^{-5}$ resulted in proportions that were $>1.0$, indicating that these values are higher than the actual mutation rate in $R$. rabida. Accordingly, I conducted analyses using a mutation rate of $1 \times 10^{-6}$ (Table 7). The highest proportions of migrants were from Rural Site B and Thurman-Hutchins Park to Blackacre State Nature Preserve, and the lowest proportions of migrants were all from Horner Wildlife Refuge. The proportion of migrants to and from each population were fairly uniform and varied between 0.053 and 0.105 . I calculated the proportion of nonmigrants in each population by subtracting the total proportion of migrants in each population from one, and proportions of non-migrants ranged from 0.540 to 0.648 .

Current estimates of the proportion of migrants and non-migrants in each population as calculated by BAYESASS+ are presented in Table $8.70 \%$ of non-migrants 
comprised most of the populations, except Rural Site C, which contained a high proportion of non-migrants (.872). Generally, the proportions of migrants from one population to another ranged from 0.012 to 0.049 . However, Rural Site $\mathrm{C}$ had the largest proportion of non-migrants, and the proportion of migrants from this population was high relative to all other populations. Rural Site B contributed the lowest proportion of migrants to Blackacre State Nature Preserve and Thurman-Hutchins Park, and ThurmanHutchins Park and Rural Site B received the highest proportion from Rural Site C. A one-tailed paired t-test comparing current versus historical proportions of migrants was significant ( $\mathrm{t}=3.629, \mathrm{df}=41, \mathrm{p}=0.043)$, with average historical proportions being higher (0.065) than current mean proportion (0.046).

Landscape Analysis

Figure 4 displays the habitat raster showing that the urban landscape had less suitable habitat than rural areas, and Figure 5 displays the corridors (least-cost paths) between all sites found by Linkage Mapper as well as Pinchpoint Mapper's current flows within those pathways. Table 9 shows the least-cost path lengths and effective resistance of those pathways. The mean least-cost path length is $30.89 \mathrm{~km}(\mathrm{SD}=17.56 \mathrm{~km})$. The longest corridor is $52.56 \mathrm{~km}$, which connects Iroquois Park and Rural Site C, while the shortest corridor is 7.90 km, between E.P. "Tom" Sawyer Park and Horner Wildlife Refuge.

The average pairwise resistance score (e.g. the average resistance for all linkages) was 52,749 ( $\mathrm{SD}=32,384.8)$. The link between Iroquois Park and Horner Wildlife Refuge 
had the highest resistance score, 120,186.1. Linkages associated with Iroquois Park contained the top five resistance scores. The link between Rural Site B and Rural Site C had the lowest score, 12,587. I failed to identify any corridors free of strong barriers, as Pinchpoint Mapper identified pinch points in all corridors, even those with low resistances and in rural areas. As mentioned above, these spiders are grassland habitat specialists, and a forested landscape may therefore create natural pinch points within the corridors. While a Mantel test did not detect a significant association between the geographic and genetic distance matrices $(r=0.085 ; \mathrm{p}=0.388)$, there was a significant association between the resistance and genetic distance matrices $(r=0.599 ; p=0.046$; Figure 6).

\section{DISCUSSION}

The results of this research suggest that urbanization correlates with isolation by resistance and has generally reduced gene flow among $R$. rabida populations. Historical rates of gene flow appear somewhat higher than contemporary rates, and a positive association exists between genetic distance and landscape resistance-a predictor variable correlated with the degree of urbanization. Nevertheless, according to BAYESASS + immigrants constitute at least $12 \%$ of every population. Thus, despite the inhibitory effects urbanization may have on gene flow in $R$. rabida, substantial connectivity among the populations appears to still exist. Low G $\mathrm{G}_{\mathrm{ST}}$ estimates, a low proportion of variation being attributable to differences among populations (AMOVA), high degrees of admixture among spatially explicit clusters, and a high proportion of migrants in each population from Rural Site C support this conclusion. Rabidosa rabida 
often occurs in suburban gardens and homes (pers. obs.), so clearly they can persist in these partially degraded areas. Collectively, these results suggest that the two modes of dispersal found in this species, cursorial and aerial, keep the levels of genetic differentiation among the populations low.

Given the low $\mathrm{G}_{\mathrm{ST}}$ estimates, gene flow among the populations is occurring and is likely maintained via a source-sink model. The populations of $R$. rabida are well connected, suggesting a source population is present (Furrer and Pasinelli 2016), and the results of this research suggest that the population at Rural Site $\mathrm{C}$ is the source population. Current estimates of migration rates indicate that Rural Site $\mathrm{C}$ contributes a large proportion of migrants to all assessed populations, and immigration rates exceed emigration rates at this site. Source populations typically possess these characteristics (Watkinson and Sutherland 1995; Manier and Arnold 2005; Schaub et al. 2010). However, further analyses are needed to definitively assess this pattern. The fine-scale genetic clustering detected by GENELAND does not match migration rate estimates or any GST estimates. For example, while GENELAND clustered the two urban populations together, these two populations receive more migrants from other populations than from each other, and the $\mathrm{G}^{\prime \prime}$ ST value between these two populations was the highest value documented. These conflicting results were possibly to due to the low number of individuals sampled as well as the low number of microsatellite markers used in the analyses.

Significant isolation by resistance occurred among the sampled populations, showing the difficulty for this species of crossing both forested landscapes (Reed et al. 2007b) and urban areas. Interestingly, in contrast to this study, Reed et al. (2011) found 
significant levels of isolation by distance. Differences in the amounts of forested areas and urban development between populations may lead to the different conclusions of the two studies. Further, the isolation by resistance may mask any detectable isolation by distance. Not only do the migration rates suggest that long-distance dispersal occurs even at current levels of urbanization, but also other studies show that resistance in the landscape affects the detection of any isolation by distance. For example, high levels of resistance between two very closely spaced populations of striped field mice in Poland masked the detection of isolation by distance (Gortat et al. 2014). The possibility also exists that the sample size is too low to detect any isolation by distance, as correlations between genetic distance and geographic distance are more likely to be significant with more loci being tested (Landguth et al. 2012).

The high levels of gene flow found in this study suggest that dispersal allows this species to persist in urban environments. Cursorial dispersal allows spiders to move short distances, and while cursorial dispersal is only effective in matrices with low resistance (Bonte and Maelfait 2001), R. rabida may find enough small areas of suitable habitat to continue to traverse the urban matrix. Spiders express cursorial behaviors more often when inhabiting low-quality habitats (Kreiter and Wise 2001, Bonte et al. 2004, Rykken et al. 2011), but the results of this study suggest that aerial dispersal predominately maintains gene flow given the distances between the sites and the resistance of the landscape.

Aerial dispersal greatly contributes to maintaining gene flow across the landscape in spiders. Reed et al. (2011) suggested that when gene flow via cursorial dispersal fails, aerial dispersal becomes important for $R$. rabida. Although relatively little research has 
addressed the effects of aerial dispersal on gene flow, aerial dispersal maintained high gene flow levels among isolated populations of Argiope trifasciata (Ramirez and Haakonsen 2001), and colonization across the Hawaiian Islands by spiders correlated with wind patterns (Gillespie et al. 2012). Currently, research on the impact of disturbed, fragmented landscapes on spider ballooning behavior suggests that habitat generalists and specialists have different responses; habitat specialists less often display aerial behaviors (Bonte et al. 2003, 2004, Entling et al. 2011), especially in small isolated populations (Bonte et al. 2006). Further, Entling et al. (2011) concluded that generalist spiderlings from disturbed habitats more often aerially dispersed than those from undisturbed habitats. The low estimated levels of genetic differentiation align with the view that $R$. rabida spiderlings frequently balloon in urban areas and that aerial dispersal plays an important role in maintaining connectivity across spatial scales that are large relative to the daily movements of adult $R$. rabida. In addition, aerial dispersal potentially explains how the Iroquois Park population is not more genetically differentiated from the other populations. Pinchpoint Mapper found a high level of resistance within the northern corridor that connects the Iroquois Park population to other populations (Figure 5), and only ballooning would allow spiderlings to successfully cross this inhospitable landscape. Intraspecific variations in dispersal behavior between $R$. rabida in Northern Mississippi and R. rabida in the Louisville area could explain the contrast between the results of this study and the conclusions of Reed et al. (2011). Populations of $R$. rabida located $10 \mathrm{~km}$ apart exhibited no gene flow in Mississippi (Reed et al. 2011), whereas the Louisville populations were separated by much greater distances and still sustained gene flow. For example, the Gst value between the Iroquois Park and Rural Site C 
populations, located $54 \mathrm{~km}$ apart, was 0.009 . Intraspecific variations in dispersal behaviors are frequent in nature and often reflect differences in the composition and structure of the landscape (Stevens et al. 2010; Matthysen 2012). Variations in dispersal behaviors have been documented in a variety of taxa including black flies (Fonesca and Hart 1996), toads (Constible et al. 2010), sea-snakes (Lane and Shine 2011), and spiders (Bonte et al. 2006). Louisville and Northern Mississippi are located in different geographic locations and also have different climatic conditions. Thus, the possibility exists that the populations in Louisville have different dispersal behaviors from populations in Mississippi. This study demonstrated how combining traditional population genetic analyses with geospatial analyses further contributes to the understanding of how altered landscapes and resistance within the landscape affect gene flow in cursorial spiders. Future studies need to investigate the differential responses of R. rabida and other spiders to urban development across the United States and identify the mechanisms that are driving these responses. 
Table 1. List of sites and their respective development category, geographic coordinates, habitat size, and name abbreviations. Sites located within Interstate 265 are considered urban, while those located outside the interstate are rural.

\begin{tabular}{lccccc}
\hline Site & Development Category & \multicolumn{2}{c}{ Coordinates } & Size $\left(\mathrm{m}^{2}\right)$ & Abbreviation \\
\hline Iroquois Park & Urban & $38^{\circ} 09^{\prime} 42^{\prime \prime} \mathrm{N}$ & $085^{\circ} 47^{\prime} 15^{\prime \prime} \mathrm{W}$ & 64533.54 & $\mathrm{IP}$ \\
Thurman-Hutchins Park & Urban & $38^{\circ} 16^{\prime} 54^{\prime \prime} \mathrm{N}$ & $085^{\circ} 41^{\prime} 26^{\prime \prime} \mathrm{W}$ & 24872.95 & $\mathrm{TH}$ \\
Blackacre State Nature Preserve & Urban & $38^{\circ} 11^{\prime} 34^{\prime \prime} \mathrm{N}$ & $085^{\circ} 31^{\prime} 30^{\prime \prime} \mathrm{W}$ & 104755.6 & $\mathrm{BA}$ \\
E.P. "Tom" Sawyer Park & Urban & $38^{\circ} 17^{\prime} 08^{\prime \prime} \mathrm{N}$ & $085^{\circ} 33^{\prime} 36^{\prime \prime} \mathrm{W}$ & 9266.528 & TSP \\
Horner Wildlife Refuge & Rural & $38^{\circ} 20^{\prime} 35^{\prime \prime} \mathrm{N}$ & $085^{\circ} 31^{\prime} 44^{\prime \prime} \mathrm{W}$ & 1582.946 & $\mathrm{HNR}$ \\
Rural Site B & Rural & $38^{\circ} 23^{\prime} 13^{\prime \prime} \mathrm{N}$ & $085^{\circ} 25^{\prime} 39^{\prime \prime} \mathrm{W}$ & 2077.007 & $\mathrm{RSB}$ \\
Rural Site C & Rural & $38^{\circ} 26^{\prime} 48^{\prime \prime} \mathrm{N}$ & $085^{\circ} 16^{\prime} 44^{\prime \prime} \mathrm{W}$ & 22198.66 & $\mathrm{RSC}$ \\
\hline
\end{tabular}

Table 2. Land cover classifications found within my $106 \mathrm{~km} \times 88 \mathrm{~km}$ area with respective habitat and resistance values. Land cover classifications are determined by the National Land Cover Database.

\begin{tabular}{lcc}
\hline Land Cover Classification & Habitat Value & Resistance \\
\hline Open Water & 0 & 50 \\
Developed, Open Space & 0.8 & 1 \\
Developed, Low Intensity & 0.7 & 2 \\
Developed, Medium Intensity & 0 & 60 \\
Developed, High Intensity & 0 & 85 \\
Barren Land & 0 & 2 \\
Deciduous Forest & 0 & 70 \\
Evergreen Forest & 0 & 50 \\
Mixed Forest & 0.1 & 25 \\
Shrub/Scrub & 0.7 & 2 \\
Herbaceous & 1 & 1 \\
Hay/Pasture & 0.9 & 1 \\
Cultivated Crops & 0.5 & 1 \\
Woody Wetlands & 0 & 40 \\
Emergent Herbaceous Wetlands & 0.1 & 30 \\
\hline
\end{tabular}


Table 3. Summary statistics for each locus in each population and mean (standard error) across all loci in a population. N: number of individuals sampled, $\mathrm{N}_{\mathrm{A}}$ : number of alleles, $\mathrm{N}_{\mathrm{EA}}$ : number of effective alleles, $\mathrm{H}_{\mathrm{O}}$ : observed heterozygosity, $\mathrm{H}_{\mathrm{E}}$ : expected heterozygosity, FIS: inbreeding coefficient (Weir and Cockerham 1984), M-Ratio: M-ratio (Garza and Williamson 2001). * indicates significant deviations from Hardy-Weinberg Equilibrium

\begin{tabular}{|c|c|c|c|c|c|c|c|c|}
\hline Population & Locus & $\mathrm{N}$ & $\mathrm{N}_{\mathrm{A}}$ & $\mathrm{N}_{\mathrm{EA}}$ & $\mathrm{H}_{\mathrm{O}}$ & $\mathrm{H}_{\mathrm{E}}$ & $\mathrm{F}_{\text {IS }}$ & M-Ratio \\
\hline \multirow[t]{6}{*}{ IP } & 1 & 22 & 12 & 7.118 & 0.864 & 0.860 & 0.019 & 0.706 \\
\hline & 2 & 26 & 5 & 2.198 & 0.269 & 0.545 & 0.508 & 0.625 \\
\hline & 3 & 23 & 7 & 3.574 & 0.652 & 0.720 & 0.117 & 0.875 \\
\hline & 4 & 26 & 3 & 1.362 & 0.154 & 0.266 & 0.437 & 0.750 \\
\hline & 5 & 24 & 19 & 14.961 & 0.875 & 0.933 & 0.084 & 0.613 \\
\hline & & $24.200(0.800)$ & $9.200(2.871)$ & $5.843(2.482)$ & $0.563(0.150)$ & $0.665(0.120)$ & $0.233(0.100)$ & $0.714(0.048)$ \\
\hline \multirow[t]{6}{*}{ TH } & 1 & 12 & 8 & 3.740 & 0.583 & 0.733 & 0.245 & 0.615 \\
\hline & 2 & 16 & 3 & 1.290 & 0.125 & 0.225 & 0.469 & 1.000 \\
\hline & 3 & 16 & 6 & 2.338 & 0.500 & 0.572 & 0.158 & 0.750 \\
\hline & 4 & 16 & 4 & 1.690 & 0.438 & 0.408 & -0.040 & 1.000 \\
\hline & 5 & 15 & 12 & 8.824 & 0.800 & 0.887 & 0.132 & 0.400 \\
\hline & & $15.000(0.775)$ & $6.600(1.600)$ & $3.576(1.376)$ & $0.489(0.110)$ & $0.565(0.117)$ & $0.193(0.083)$ & $0.753(0.115)$ \\
\hline \multirow[t]{6}{*}{ TSP } & 1 & 12 & 9 & 6.545 & 0.667 & 0.847 & 0.254 & 0.900 \\
\hline & 2 & 12 & 4 & 1.419 & 0.250 & 0.295 & 0.195 & 0.667 \\
\hline & 3 & 15 & 6 & 4.500 & 0.533 & 0.778 & 0.345 & 0.750 \\
\hline & 4 & 4 & 5 & 3.200 & 0.750 & 0.688 & 0.053 & 0.625 \\
\hline & 5 & 15 & 16 & 11.250 & 0.733 & 0.911 & 0.228 & 0.727 \\
\hline & & $11.600(2.015)$ & $8.000(2.168)$ & 5.383 (1.689) & $0.587(0.092)$ & $0.703(0.109)$ & $0.215(0.048)$ & $0.734(0.047)$ \\
\hline \multirow[t]{4}{*}{ BA } & 1 & 13 & 8 & 4.694 & 0.692 & 0.787 & 0.160 & 0.727 \\
\hline & 2 & 16 & 6 & 2.462 & 0.438 & 0.594 & 0.293 & 0.667 \\
\hline & 3 & 15 & 7 & 4.327 & 0.733 & 0.769 & 0.081 & 0.636 \\
\hline & 4 & 10 & 6 & 1.961 & 0.500 & 0.490 & 0.032 & 0.750 \\
\hline
\end{tabular}




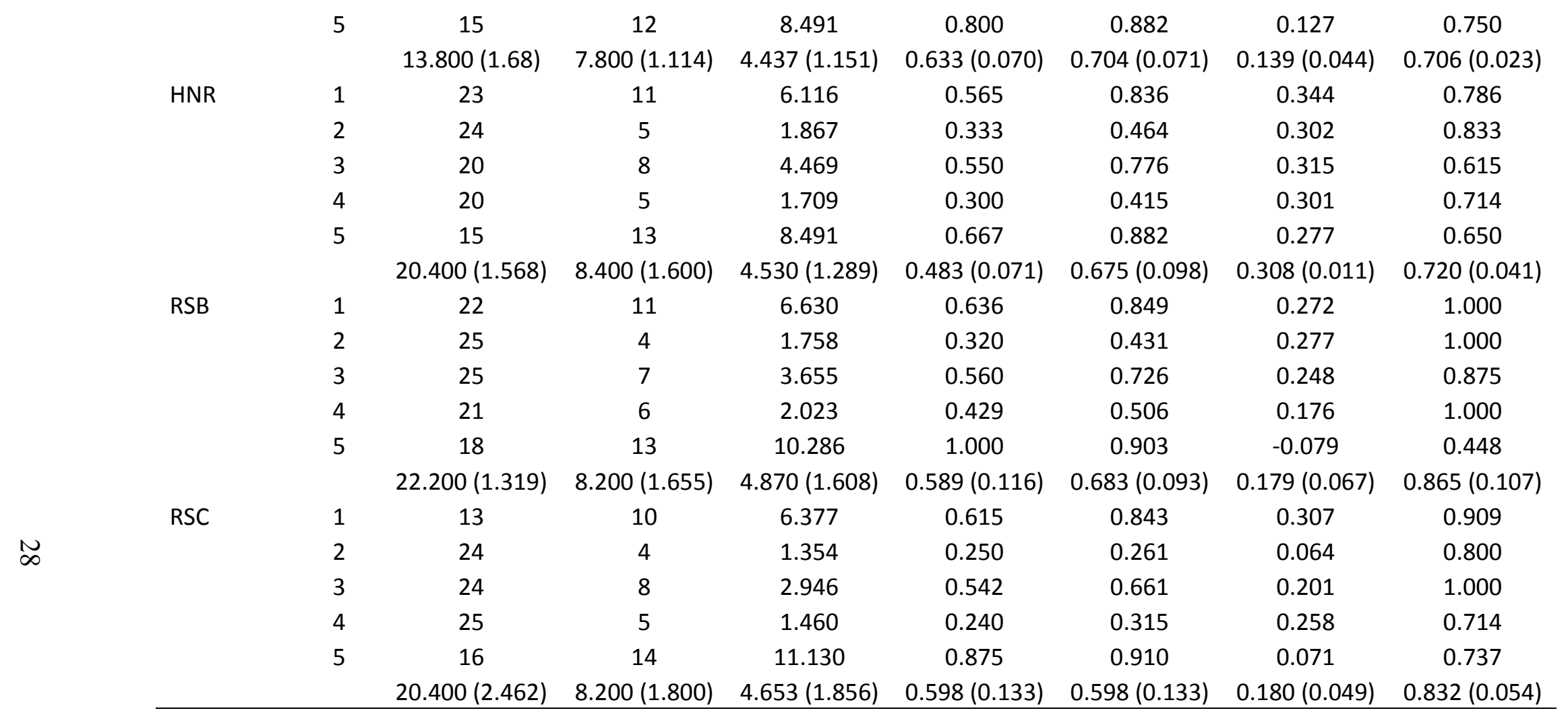

Table 4. Pairwise Gst values and uncorrected $P$-values among all sites. Gst values are below the diagonal and $P$-values are above.

$\begin{array}{lccccccc} & \text { IP } & \text { TH } & \text { TSP } & \text { BA } & \text { HNR } & \text { RSB } & \text { RSC } \\ \text { IP } & & 0.002 & 0.020 & 0.075 & 0.052 & 0.011 & 0.028 \\ \text { TH } & 0.019 & & 0.071 & 0.184 & 0.062 & 0.071 & 0.495 \\ \text { TSP } & 0.014 & 0.011 & & 0.574 & 0.344 & 0.131 & 0.303 \\ \text { BA } & 0.007 & 0.006 & -0.001 & & 0.685 & 0.243 & 0.391 \\ \text { HNR } & 0.008 & 0.010 & 0.002 & -0.003 & & 0.199 & 0.567 \\ \text { RSB } & 0.011 & 0.009 & 0.007 & 0.003 & 0.004 & & 0.110 \\ \text { RSC } & 0.009 & 0.002 & 0.004 & 0.002 & 0.000 & 0.007 & \end{array}$


Table 5. Pairwise $G^{\prime \prime}$ st values and uncorrected p-values among all sites. G"st values are below the diagonal and $P$-values are above. After correcting for multiple testing, no values are significant.

$\begin{array}{lccccccc} & \text { IP } & \text { TH } & \text { TSP } & \text { BA } & \text { HNR } & \text { RSB } & \text { RSC } \\ \text { IP } & & 0.004 & 0.014 & 0.070 & 0.046 & 0.013 & 0.030 \\ \text { TH } & 0.103 & & 0.064 & 0.185 & 0.067 & 0.080 & 0.492 \\ \text { TSP } & 0.095 & 0.067 & & 0.580 & 0.330 & 0.126 & 0.276 \\ \text { BA } & 0.051 & 0.033 & -0.011 & & 0.689 & 0.235 & 0.382 \\ \text { HNR } & 0.049 & 0.057 & 0.013 & -0.019 & & 0.202 & 0.556 \\ \text { RSB } & 0.069 & 0.052 & 0.048 & 0.024 & 0.025 & & 0.102 \\ \text { RSC } & 0.053 & 0.008 & 0.023 & 0.013 & 0.000 & 0.038 & \end{array}$

Table 6. AMOVA results examining genetic variation at different scales. Variation among populations accounted for only $4.3 \%$ of the variation found, with $34.7 \%$ of the variation found among individuals and the majority $(61.0 \%)$ of the variation within individuals.

\begin{tabular}{cccccccc}
\hline & df & SS & MS & $\begin{array}{c}\text { Variance } \\
\text { Component }\end{array}$ & $\begin{array}{c}\text { Percent } \\
\text { Variation }\end{array}$ & $\begin{array}{c}\text { Fixation } \\
\text { Index }\end{array}$ & P-value \\
\hline Among Populations & 6 & 34.423 & 5.737 & 0.078 & 4.284 & $\mathrm{~F}_{\mathrm{ST}}=0.043$ & $<0.001$ \\
Among Individuals & 144 & 343.809 & 2.388 & 0.636 & 34.743 & $\mathrm{~F}_{\mathrm{IS}}=0.363$ & $<0.001$ \\
Within Individuals & 151 & 168.500 & 1.116 & 1.116 & 60.973 & $\mathrm{~F}_{\mathrm{IT}}=0.390$ & $<0.001$ \\
Total & 301 & 546.732 & & 1.830 & 100.000 & & \\
\hline
\end{tabular}


Table 7. Historical mean estimates of proportion of migrants and non-migrants within each population as estimated from MIGRATE. Values along the diagonal represent the proportion of non-migrants within the population, and values above and below the diagonal represent the proportion of migrants within the population. Column names indicate source population and row names indicate sampled population.

Historical estimates have been calculated with a mutation rate of $1 \times 10^{-6}$. The highest proportions of migrants were from Rural Site B and Thurman-Hutchins Park to Blackacre State Nature Preserve, and the lowest proportions of migrants were all from Horner Wildlife Refuge. The proportion of migrants to and from each population ranged from 0.053 to 0.105 . Note, MIGRATE does not provide standard deviations.

$\begin{array}{lccccccc} & \text { IP } & \text { TH } & \text { TSP } & \text { BA } & \text { HNR } & \text { RSB } & \text { RSC } \\ \text { IP } & 0.591 & 0.083 & 0.073 & 0.070 & 0.053 & 0.075 & 0.056 \\ \text { TH } & 0.055 & 0.648 & 0.058 & 0.063 & 0.053 & 0.066 & 0.056 \\ \text { TSP } & 0.062 & 0.062 & 0.648 & 0.055 & 0.053 & 0.060 & 0.060 \\ \text { BA } & 0.060 & 0.100 & 0.071 & 0.540 & 0.053 & 0.105 & 0.070 \\ \text { HNR } & 0.064 & 0.070 & 0.071 & 0.058 & 0.618 & 0.055 & 0.063 \\ \text { RSB } & 0.058 & 0.085 & 0.062 & 0.059 & 0.053 & 0.629 & 0.054 \\ \text { RSC } & 0.064 & 0.074 & 0.072 & 0.059 & 0.053 & 0.067 & 0.611\end{array}$


Table 8. Current mean (SD) proportion of migrants and non-migrants within each population as estimated from BAYESASS+.

Row names indicate the populations that the migrants disperse to, and column names indicate the source population. Values along the diagonal show the number of non-migrants within each population. Most populations contained approximately $70 \%$ non-migrants, except Rural Site C, which contained a high percentage (87.2\%) of non-migrants.

$\begin{array}{cccccccc} & \text { IP } & \text { TH } & \text { TSP } & \text { BA } & \text { HNR } & \text { RSB } & \text { RSC } \\ \text { IP } & 0.732(0.045) & 0.013(0.013) & 0.015(0.014) & 0.013(0.012) & 0.018(0.018) & 0.018(0.018) & 0.192(0.046) \\ \text { TH } & 0.020(0.019) & 0.682(0.014) & 0.016(0.015) & 0.015(0.015) & 0.016(0.015) & 0.017(0.016) & 0.235(0.033) \\ \text { TSP } & 0.049(0.037) & 0.024(0.023) & 0.699(0.029) & 0.021(0.020) & 0.034(0.029) & 0.036(0.032) & 0.137(0.048) \\ \text { BA } & 0.029(0.025) & 0.021(0.020) & 0.021(0.019) & 0.689(0.020) & 0.029(0.024) & 0.021(0.020) & 0.192(0.039) \\ \text { HNR } & 0.028(0.024) & 0.014(0.013) & 0.016(0.014) & 0.014(0.013) & 0.695(0.026) & 0.020(0.018) & 0.214(0.040) \\ \text { RSB } & 0.018(0.017) & 0.012(0.012) & 0.015(0.014) & 0.012(0.011) & 0.016(0.015) & 0.696(0.024) & 0.231(0.035) \\ \text { RSC } & 0.034(0.030) & 0.016(0.015) & 0.017(0.016) & 0.016(0.015) & 0.022(0.021) & 0.024(0.020) & 0.872(0.040)\end{array}$


Table 9. List of the least-cost path length (meters, LCP Length) and effective resistance of all linkages between sites, as calculated by Circuitscape. Linkages associated with Iroquois Park contained the top five resistance scores. The link between Rural Site B and Rural Site C had the lowest score, 12,587. All corridors had strong barriers,

\begin{tabular}{llcc}
\hline Population 1 & Population 2 & $\begin{array}{c}\text { LCP } \\
\text { Length }\end{array}$ & $\begin{array}{c}\text { Effective } \\
\text { Resistance }\end{array}$ \\
\hline Iroquois Park & Thurman Hutchins Park & 20980 & 100509.66 \\
Iroquois Park & E.P. "Tom" Sawyer Park & 28192 & 89223.17 \\
Iroquois Park & Blackacre State Nature Preserve & 35842 & 55384.10 \\
Iroquois Park & Horner Wildlife Refuge & 35441 & 120186.07 \\
Iroquois Park & Rural Site B & 49530 & 111845.24 \\
Iroquois Park & Rural Site C & 84658 & 83142.84 \\
Thurman Hutchins Park & E.P. "Tom" Sawyer Park & 14217 & 40078.29 \\
Thurman Hutchins Park & Blackacre State Nature Preserve & 25296 & 43088.57 \\
Thurman Hutchins Park & Horner Wildlife Refuge & 19153 & 64823.65 \\
Thurman Hutchins Park & Rural Site B & 33242 & 56395.64 \\
Thurman Hutchins Park & Rural Site C & 52562 & 68582.23 \\
E.P. "Tom" Sawyer Park & Blackacre State Nature Preserve & 13166 & 14874.88 \\
E.P. "Tom" Sawyer Park & Horner Wildlife Refuge & 7904 & 28555.87 \\
E.P. "Tom" Sawyer Park & Rural Site B & 20553 & 18263.02 \\
E.P. "Tom" Sawyer Park & Rural Site C & 39873 & 30460.21 \\
Blackacre State Nature Preserve & Horner Wildlife Refuge & 22769 & 49617.42 \\
Blackacre State Nature Preserve & Rural Site B & 30848 & 43835.43 \\
Blackacre State Nature Preserve & Rural Site C & 48838 & 27564.31 \\
Horner Wildlife Refuge & Rural Site B & 13059 & 18252.63 \\
Horner Wildlife Refuge & Rural Site C & 32379 & 30449.82 \\
Rural Site B & Rural Site C & 20219 & 12587.24 \\
\hline & & & \\
\hline
\end{tabular}




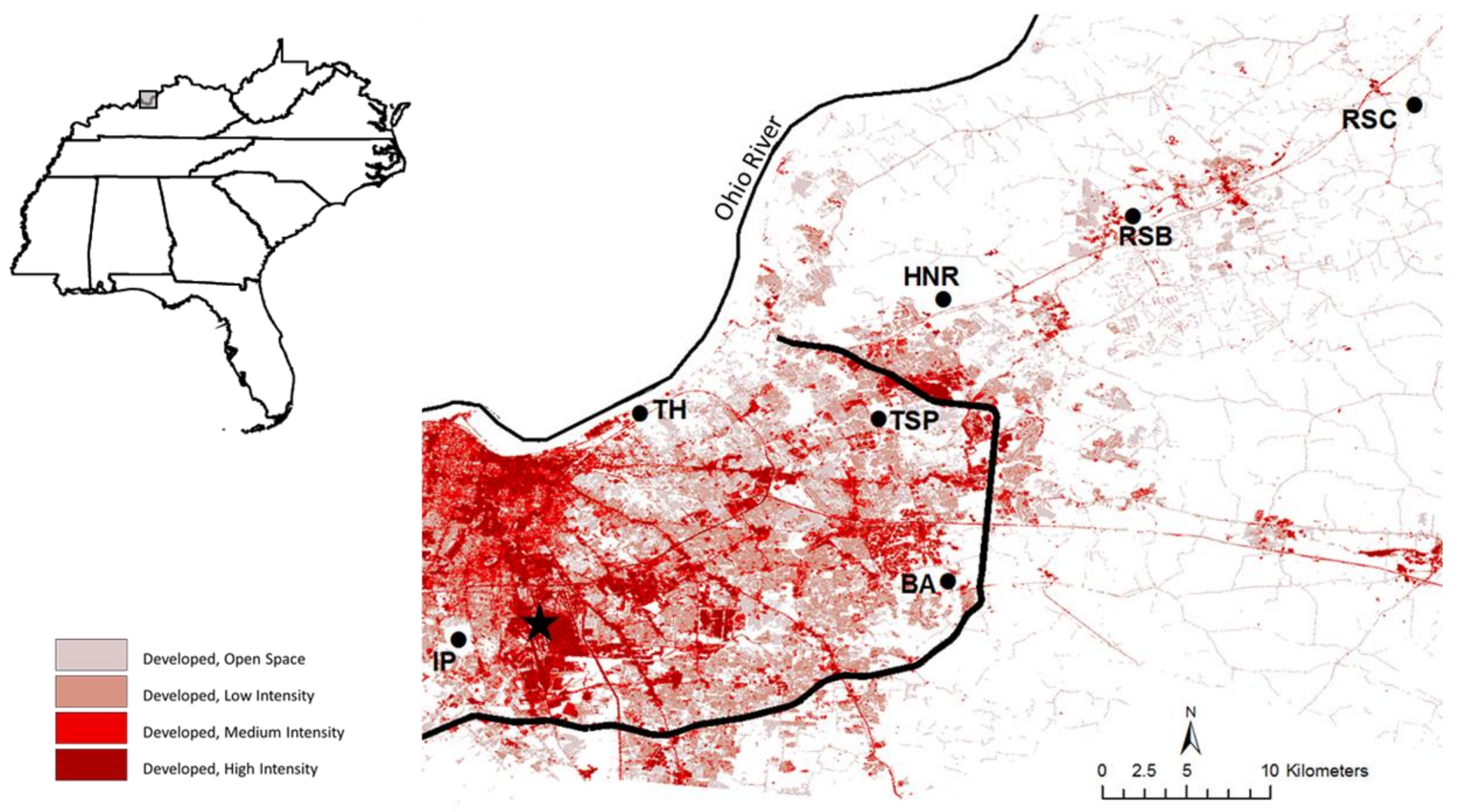

Figure 1. A map of the seven field sites with Interstate 265 separating urban and rural sites and urbanization intensity across the landscape. The star shows the location of the Louisville International Airport, and the heavy bold line shows Interstate 265. See Table 1 for list of site abbreviations. Urban development categories are from the National Land Cover Database. 

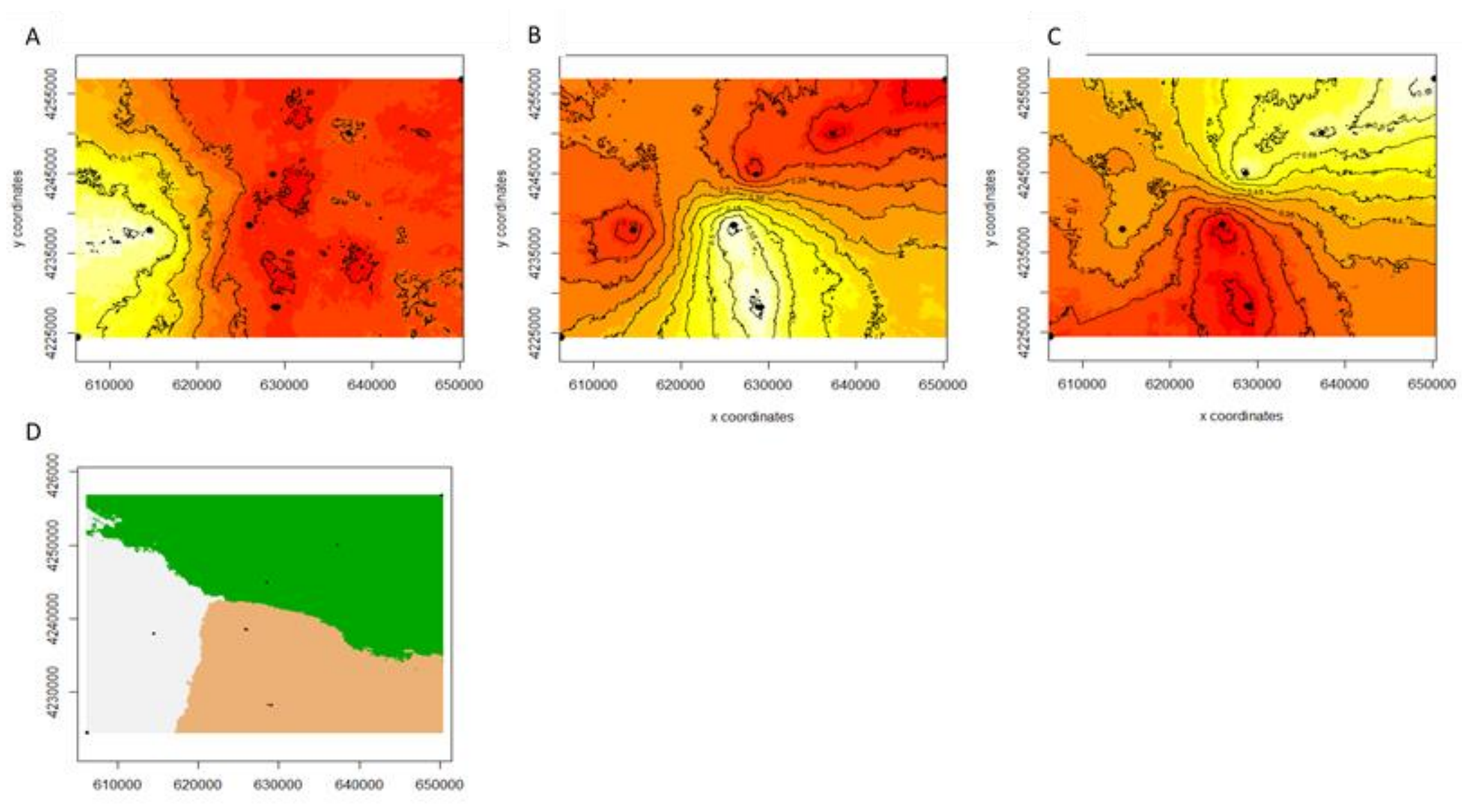

Estimated custer membership

Figure 2. (A-C) Posterior probabilities of the likelihood of an individual belonging to a certain genetic cluster. White to light yellow areas indicate a high likelihood and red areas indicate a low likelihood. (D) Genetic clustering of all sites. Spiders from the four urban sites grouped into two clusters, which are shown in pink (Iroquois Park and Thurman-Hutchins Park) and 
green (E.P. "Tom" Sawyer Park and Blackacre State Nature Preserve). Spiders from the three rural sites (Horner Wildlife Refuge, Rural Site B, and Rural Site C) belong to a third cluster, shown in grey. 


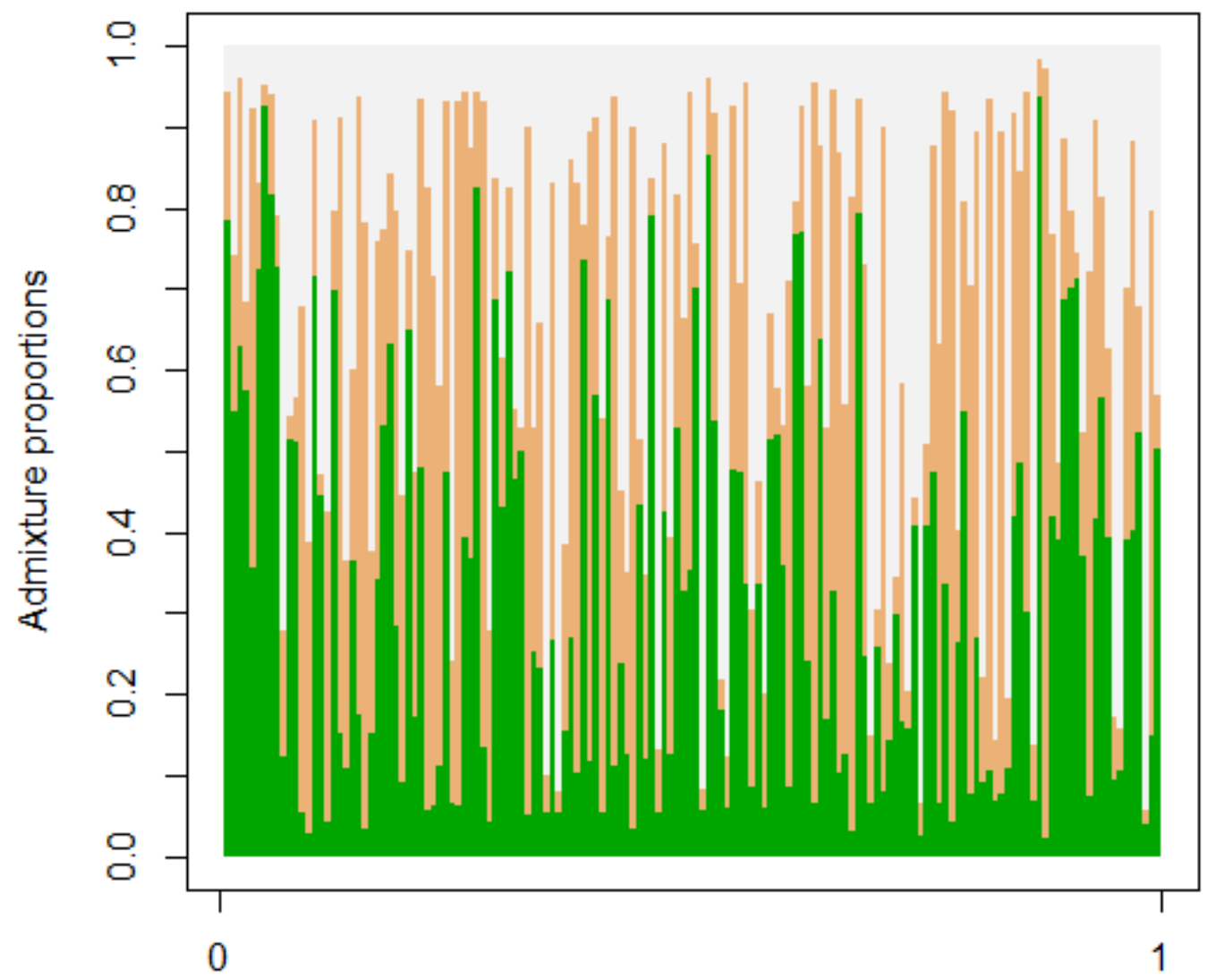

Spatial coordinate along a one-dimensional axis

Figure 3. Admixture proportions estimated from GENELAND. Each column represents an individual; each bar within the column reflects the proportion of the individual's genotype that is genetically similar to any of the three genetic clusters. Pink bands indicate genetic similarities to cluster 1 , green bands indicate genetic similarities to cluster 2 , and grey bands indicate genetic similarities to cluster 3 . The $\mathrm{x}$-axis represents the geographical line across which admixture is tested, east (0) to west (1). All individuals were admixed, showing that the sampled populations were not well differentiated from one another. 


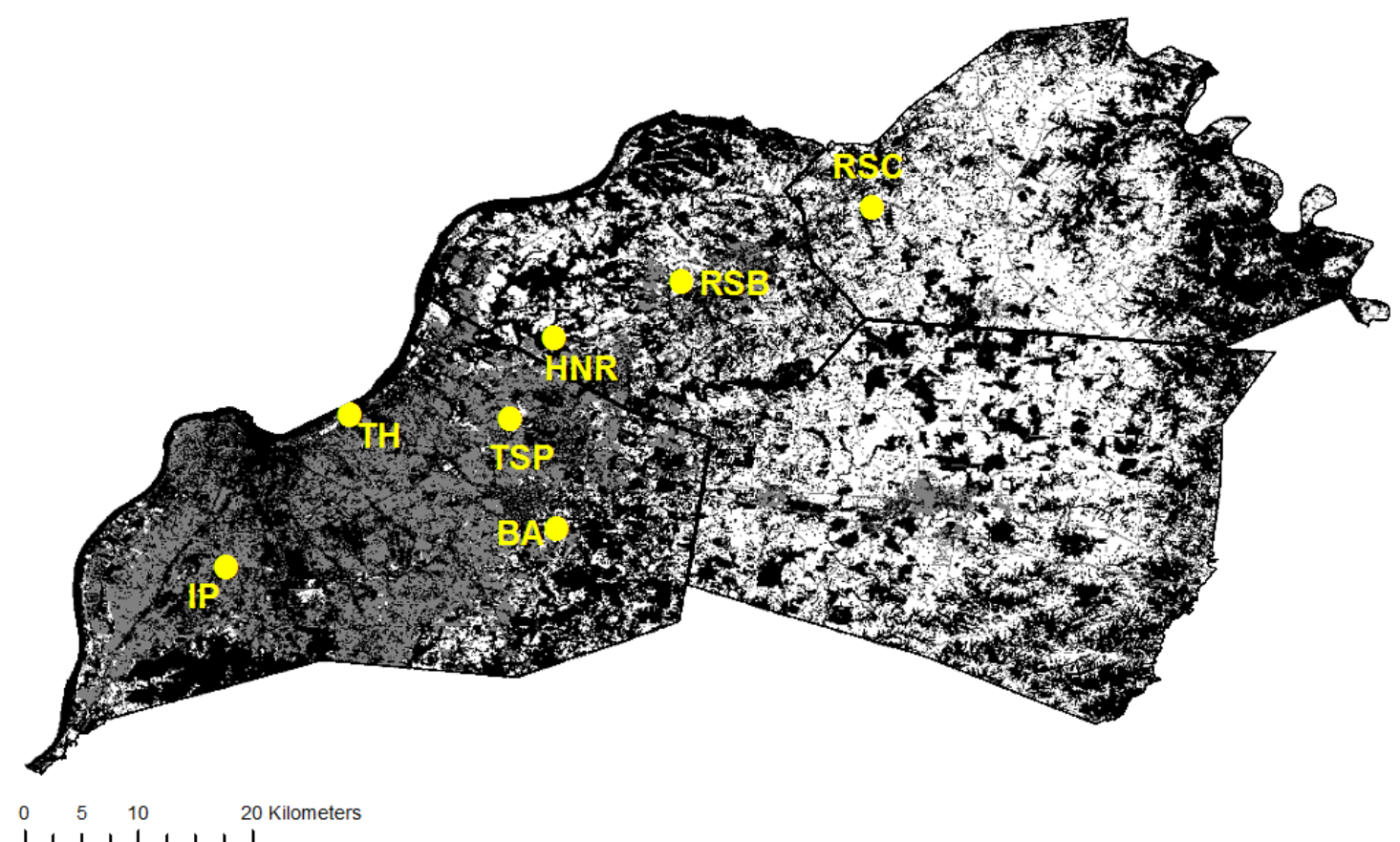

Figure 4. Habitat raster, developed by Gnarly Landscape Utilities, depicting quality of the landscape for suitable habitat. The lighter the color, the more suitable the habitat. Rural areas had more suitable habitat than do urban areas. 


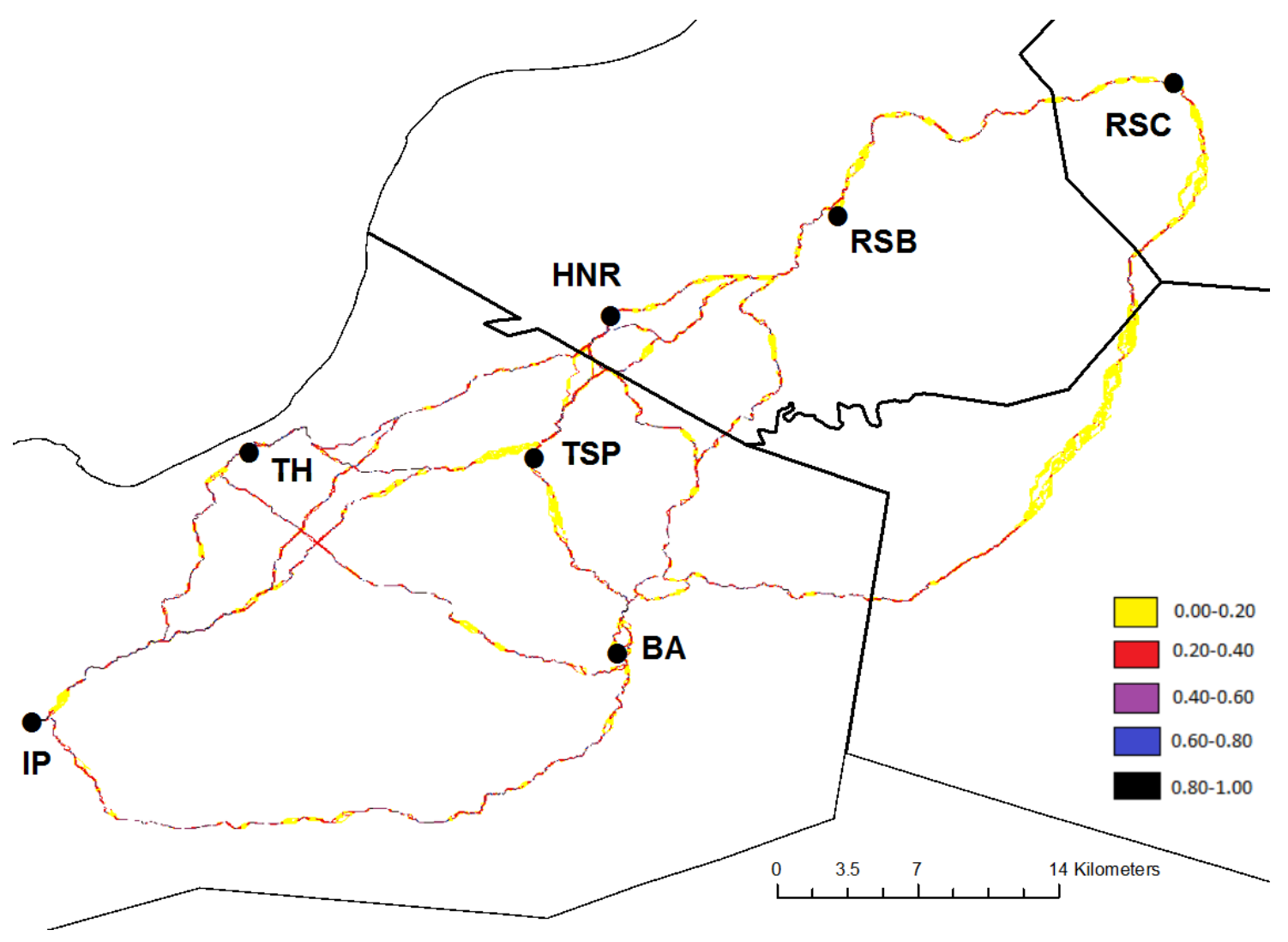

Figure 5. Least-cost paths identified from Linkage Mapper incorporated with Pinchpoint Mapper's current flows. Higher values indicate higher currents indicating locations where the corridor narrows and dispersal becomes more difficult. There is a high level of resistance within the northern path connecting Iroquois Park (IP) with other parks. 


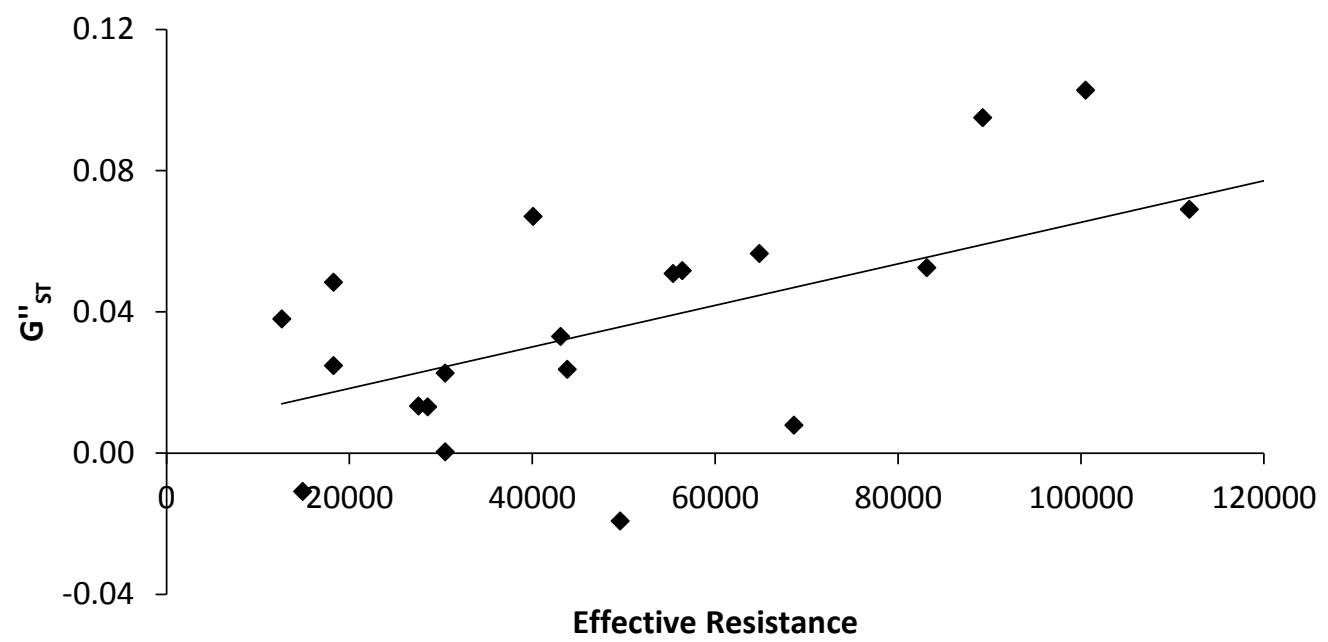

Figure 6. Mantel test showing a significant association between the resistance and genetic distance matrices $(\mathrm{r}=0.599 ; \mathrm{p}=0.046)$. 


\title{
CHAPTER III
}

\section{URBANIZATION DIFFERENTLY AFFECTS POND AND STREAM ODONATE COMMUNITIES}

\begin{abstract}
SUMMARY
Habitat alteration via urbanization has very different effects on even closely related taxa. However, most research investigating the ecological effects of urbanization focuses on birds or mammals, resulting in a poor understanding of the responses of invertebrate populations. I quantified the differences in the diversity of odonates (dragonflies and damselflies) at lentic and lotic sites between urban and rural landscapes and examined environmental factors that might affect community composition. Urbanization significantly lowered lentic damselfly species richness but did not alter lentic dragonfly species richness. Changes in lentic odonate community composition were associated with the amount of urban development within 150 of each site, mean algal coverage, and distance to the urban center. At lotic sites, water temperature and distance to the urban center influenced odonate communities. Inherent differences between dragonflies versus damselflies and between lentic versus lotic ecosystems likely drive the differing responses to urbanization observed in this study. Given that different environmental factors affect taxa differently in lentic and lotic sites, maintaining the highest level of odonate diversity possible across a landscape will require the use of different management practices for each ecosystem type.
\end{abstract}




\section{INTRODUCTION}

Urbanization profoundly affects biodiversity, and as cities continue to grow, the impact increases. Approximately 3.9 billion people currently inhabit urban areas;

projections expect that number to rise to 6.3 billion by 2050 (United Nations 2015) and the land area occupied by cities will triple from 2000 to 2030 (Seto et al. 2012). The consequences of urbanization for animal species depend on the degree of urbanization and vary among taxa and ecosystems. In part, because of this complexity, our understanding of how urbanization affects animal communities remains inadequate, although major drivers of extinction include habitat loss and fragmentation (Wilcox and Murphy 1985; Fahrig 1997; Heinrichs et al. 2016). Further, urban development results in high rates of extinction for many native taxa (Vale and Vale 1976; Marzluff 2001; McDonald et al. 2008; Aronson et al. 2014). Taxonomic bias in research has hampered our understanding of the effects of urbanization on animal taxa-only $10-12 \%$ of studies of urban wildlife in the 1990s and 2000s focused on arthropods, for example, while 38\% focused on mammals and 43\% on birds (Magle et al. 2012).

Urbanization commonly affects both species richness and community composition. In vertebrates, species richness typically declines along a rural to urban gradient (reviewed in McKinney 2008; Urban et al. 2006; Pillsbury and Miller 2008; Van Nuland and Whitlow 2014), although sites with intermediate levels of urbanization hold higher avian species richness levels than rural or highly urbanized areas (Chace and Walsh 2006). Although relatively little studied, invertebrate responses to urbanization are complex and vary across taxa. Similar to the vertebrate pattern, invertebrate species richness generally declines along rural to urban gradients (Hansen et al. 2005; reviewed 
by McKinney 2008). However, some species richness patterns also show neutral responses (reviewed by Faeth et al. 2011; Jones and Leather 2012), such as in nematodes (Pavao-Zuckerman and Coleman 2007), isopods (Hornung et al. 2007), and wasps (Christie and Hochuli 2009), and other taxa experience increased species richness in urban areas (carabids: Magura et al. 2004; spiders: Magura et al. 2010). In butterflies, the highest species richness can occur at intermediate levels of urbanization (Blair 1999), and tropical gardens hold more species than primary or secondary forests (Kudavidanage et al. 2011).

Urbanization also affects community composition for both vertebrates and invertebrates, and the ability of species to persist in urban areas depends on speciesspecific traits. (Chace and Walsh 2006; Scott 2006; Thompson and McLachlan 2007; Pillsbury and Miller 2008; Alexandre et al. 2010). Urban animal communities typically have lower diversity than those in less altered habitats (McKinney 2002; Shochat et al. 2006; Luck and Smallbone 2010), and often widespread, non-native species replace native species, resulting in homogenization at urban sites (McKinney and Lockwood 1999; Blair 2004; McKinney 2006; Horsák et al. 2013; Knop 2016; but see Olden and Rooney 2006). Habitat specialization may relate to species persistence in urban areas, with urban species possessing broader habitat tolerances (McKinney and Lockwood 1999; Devictor et al. 2007). Dispersal ability also affects species persistence; species with strong dispersal capabilities can traverse urban matrices (Bierwagen 2007) and thus may be more likely to persist. Differences in dispersal capability explained variation in the responses of some terrestrial and aquatic arthropods to urbanization (Vergnes et al. 
2012; Smith et al. 2105), but did not affect urban carabid beetle communities (Weller and Ganzhorn 2004).

Urbanization negatively influences aquatic and terrestrial ecosystems (Paul and Meyer 2001; Hassall 2014), although studies predominantly focus on terrestrial habitats (Abel 2002; Dudgeon et al. 2006). Habitat fragmentation (Fahrig 2003; Fuller et al. 2015; Haddad et al. 2015), exotic species introductions (Gurevitch and Padilla 2004; Havel et al. 2015) and increased temperatures (Pickett et al. 2001; Grimm et al. 2008; Somers et al. 2013) alter both aquatic and terrestrial communities in urbanized environments. In aquatic habitats, because impervious surface cover replaces native vegetation, freshwater systems suffer from increased run-off of pollutants and nutrients into the water (Booth and Jackson 1997) and increased water temperatures driven by increases in air temperatures (Brönmark and Hansson 2002; Nelson and Palmer 2007). Decreased canopy cover further increases water temperatures (Somers et al. 2013). These anthropogenic factors reduce species richness and alter community composition in aquatic communities (Roy et al. 2003; Morse et al. 2003; Moore and Palmer 2005; Cuffney et al. 2010; Collier and Clements 2011; de Jesús-Crespo and Ramírez 2011). However, lentic and lotic habitats do not always suffer the same degradation or respond in the same ways to urbanization. Unlike ponds, streams additionally suffer from increased erosion and higher flow rates (Booth and Jackson 1997; Paul and Meyer 2001; Allan 2004), which further contribute to altered communities and reduced species richness in urbanized areas (Kennen et al. 2010; Marshall et al. 2010). Just as urbanization differently affects a single taxon inhabiting different terrestrial ecosystems 
(Ogai and Kenta 2015), the inherent differences in lentic and lotic ecosystems may drive dissimilar responses of aquatic invertebrates inhabiting both systems.

Important predictors of odonate species richness and community composition in urban ponds (Aliberti Lubertazzi and Ginsberg 2010; Goertzen and Suhling 2013; Jeanmougin et al. 2014) and streams (Samways and Steytler 1996; Monteiro-Júnior 2013, 2014, 2015) include $\mathrm{pH}$ levels and the presence and characteristics of surrounding vegetation (for example canopy cover and emergent vegetation). Few studies have examined odonate communities across aquatic habitat types within an urban landscape, and most did not consider which environmental variables drove detected differences between lentic and lotic communities. One study identified locations of endangered species and which habitats possessed high odonate diversity (Küry and Christ 2010) and another merely identified how many odonate species inhabited an urban area (Craves and O’Brien 2013). Only Willigalla and Fartmann (2012) examined both lentic and lotic ecosystems, and they found that overall odonate species richness correlated with climate factors, but this study did not analyze lentic and lotic ecosystems separately. Thus, we still do not fully understand whether pond and stream communities respond in a similar manner to urban development. Additional studies will not only contribute to the understanding of how ecosystem degradation threatens odonates specifically, but will also provide further insight into the general response of insects to urban development.

Because the life histories of dragonflies and damselflies include both an aquatic larval stage and a terrestrial adult stage, odonate communities should reflect the effects of urbanization on ecosystems (Samways and Steytler 1996; Corbet 1999; Goertzen and Suhling 2013, 2015; Jeanmougin et al. 2014; Villalobos-Jiménez et al. 2016). However, 
previous research shows that odonate communities vary in their response to urbanization. A recent review concluded that urban development usually lowers odonate species richness (Villalobos-Jiménez et al. 2016), although urbanization had no effect or a positive effect on richness in approximately one-third of studies. Further, even small, urban bodies of water can maintain high odonate species richness (Aliberti Lubertazzi and Ginsberg 2010; Craves and O’Brien 2013; Goertzen and Suhling 2013; but see Fattorini 2014).

In this study, I examined whether odonate communities at lentic and lotic habitats within the same landscape respond similarly to urbanization. The objectives were to examine whether odonate species richness and community composition significantly differ between urban and rural areas and to identify which environmental variables are associated with any changes in community composition.

\section{METHODS}

Study Sites

I surveyed ten ponds (five urban and five rural) and ten streams (five urban and

five rural) in and around Louisville, Kentucky $\left(38^{\circ} 15^{\prime} \mathrm{N}-85^{\circ} 45^{\prime} \mathrm{W}\right.$; population: 763,623 Figure 7; Table 10; US Census Bureau 2010). I categorized a site as urban if more than $30 \%$ of a $150-\mathrm{m}$ zone surrounding the stream or pond consisted of urban development. The sites were primarily located within city parks, but four were located on private lands and two were on state or federal property. To decrease the possibility of odonates travelling between survey sites, I selected sites at least $1 \mathrm{~km}$ away from other sites, with 
the exception of one pond and one stream site (Angler Lake and Floyds Fork), which were located $0.2 \mathrm{~km}$ apart. Pond size ranged from 0.3 to 28.1 hectares. Because most ponds in Louisville contain stocked or released pet fishes, I surveyed only ponds and streams that contained fishes, which are predators of odonate larvae. Shoreline vegetation, an important factor for larval odonate emergence (Corbet 1999), was present at all surveyed ponds, but not in streams. Surveyed streams were perennial and varied from $1.6 \mathrm{~m}$ to $35.9 \mathrm{~m}$ in width. All the streams are located within the Salt River Basin and are direct or indirect tributaries of the Ohio River.

\section{Surveys}

To encompass the flight seasons of local odonate species, I surveyed all sites three times during May-August 2015, with at least one month between visits to the same site (Jeanmougin et al. 2014). To ensure high odonate diversity during my surveys, I conducted them between 09:00 and 16:30 hours when the temperature was over $17.5^{\circ} \mathrm{C}$ in the shade and when I estimated cloud cover to be less than 50\% (Jeanmougin et al. 2014). For surveys, I walked 10-m linear transects along the water's edge and identified each odonate I encountered to species. A distance of one meter separated transects at a site, and I walked each transect in 6 minutes. I followed a rule-based stopping protocol (Watson 2003) to determine when a survey was complete so that my surveys accurately reflected the diversity of each site. A survey ended when three consecutive transects revealed no new species for a given site on that day. If I could not immediately identify an individual, I paused the survey until I made the identification. I used binoculars to 
identify distant individuals, and if I was unable to identify an individual, when possible I used a standard insect net to capture it and then identified it using a field guide. I combined Tramea onusta and T. carolina as Tramea sp. because I was unable to reliably distinguish or capture them for identification, but I left the distinctive $T$. lacerata as a single species.

\section{Environmental Variables}

I measured several environmental factors at each site. I used a Hydrolab Surveyor4 with an MS5 sonde to obtain the temperature and luminescent dissolved oxygen of the water at each site during each visit. To assess the availability of perching and oviposition sites at each site, I assessed the amount of emergent vegetation, algae, and miscellaneous debris along the edge of the water for every meter surveyed during a visit. Miscellaneous debris consisted of all items floating on the water that were not plants or algae, e.g., floating/emergent sticks, leaves, and anthropogenic litter. I placed a $1 \mathrm{~m}^{2}$ square quadrat made of PVC pipe over the water at each meter surveyed and estimated to the nearest ten percent the percentage of the quadrat covered by each of emergent vegetation, algae, and miscellaneous debris. For analysis, I averaged all environmental variables measured at each site across all three sampling times, with the exception of water temperature and dissolved oxygen, which we measured only during the second and third surveys at each site.

Using data from the National Land Cover Database 2011 (NLCD) (Homer et al. 2015), I quantified the proportion of urban land use within $150 \mathrm{~m}$ of each study site 
(Kutcher and Bried 2014). The NLCD classifies the landscape into 16 possible land-use categories at a resolution of $30 \mathrm{~m}$, with four of those categories describing urban land use: 1) developed, open space; 2) developed, low intensity; 3) developed, medium intensity; and 4) developed, high intensity. Open space urban development consists of mowed areas and $<20 \%$ impervious surface cover; low intensity urban development consists of $20 \%$ to $49 \%$ impervious surface cover. Medium intensity urban development consists of 50 to $79 \%$ impervious surface cover, and high intensity urban development consists of $80-100 \%$ impervious surface cover. I ground-truthed each site to ensure that the NLCD produced accurate information, and I corrected cell categories as needed. In particular, I corrected the tendency of the NLCD to place cells located within parks into the "herbaceous" category when those cells should be in the "developed, open space" category, which by definition includes the open spaces of parks. I then calculated the proportion of urban cells within the 150-m buffer zone around each study site.

\section{Statistical Analysis}

I reported all means with standard deviations and performed all statistical analyses using the statistical software R v 3.1.1 (R Core Development Team 2015). I performed all analyses on community data summed across all seasons. First, I conducted a correlation of species richness with site size to determine whether site size should be included in further analyses. I then performed generalized linear mixed models using the lme4 package v 1.1-122 (Bates et al. 2015) to compare odonate species richness between urban and rural sites for each ecosystem type. I also did this separately for the two 
suborders Anisoptera and Zygoptera. I next determined whether pond and stream community compositions differed, using a two-factor permutational multivariate analysis of variance (PERMANOVA) with the factors being type of aquatic ecosystem (pond or stream) and urbanization level (urban or rural). This PERMANOVA yielded a significant $\mathrm{p}$-value $(p=0.037)$, so I then compared urban versus rural sites within each ecosystem using one-factor PERMANOVAs. All tests used Jaccard's measure of similarity and ran with 9999 permutations in the Vegan package v 2.0-10 (Oksanen et al. 2013). I used non-metric multidimensional scaling (NMDS) to visualize the data for each PERMANOVA.

To examine the effects of environmental variables on dragonfly community composition, I first log-transformed the environmental data to linearize the relationship between the variables and community composition. I then performed separate forwardselection canonical correspondence analyses (CCA) (Ter Braak 1986) for ponds and streams, using significance of $p \leq 0.10$ as the cut-off value for inclusion in further models. I ran each analysis with 1000 permutations in each step. To determine whether the variation explained by the axes was significant, I performed a permutational ANOVA on each axis in the final model.

Finally, I conducted indicator species analyses to investigate whether certain species were characteristic of either ecosystem (pond versus stream) or land use type (urban versus rural) within each ecosystem. I ran all tests with 9999 permutations in the indicspecies package v 1.7.5 (De Caceres and Legendre 2009). To reduce the likelihood of a Type I error, I used Holm's (1979) correction for multiple testing on all tests that 
found more than four species to be significantly associated with a system or urbanization level (De Caceres and Legendre 2009).

\section{RESULTS}

I observed 50 odonate species, including 20 zygopterans and 30 anisopterans (Table 11), which is $32 \%$ of the 157 species documented in Kentucky (NatureServe Explorer 2009). Of the 50 observed species, 21 species (four zygopterans and 17 anisopterans) were only found at ponds, six species (three zygopterans and three anisopterans) were only at streams, and 23 species (13 zygopteran and 10 anisopteran) occurred at both ponds and streams. No significant correlation existed between pond species richness and pond size $(\mathrm{r}=-0.27, p=0.44)$. Species richness significantly differed between dragonflies and damselflies at urban and rural pond sites $(p=0.03)$ but not at stream sites $(p=0.34)$. Odonate species richness did not differ significantly between rural ponds $(\bar{X}=19.6 \pm 3.0$ species; range: $15-23$ species $)$ and urban ponds $(\bar{X}=$ $15.4 \pm 1.5$ species; range: $13-17$ species; $p=0.11$ ) nor did rural and urban stream species richness differ significantly (rural: $\bar{X}=10.0 \pm 3.1$ species; range: $6-13$ species; urban: $\bar{X}=$ $7.0 \pm 2.1$ species; range: $4-10$ species; $p=0.10$; Figure 8 ). Anisopteran species richness did not differ significantly between rural and urban ponds (rural: $\bar{X}=12.2 \pm 3.6$ species; range: 7-17 species; urban: $\bar{X}=12.0 \pm 1.6$ species; range: $10-14$ species; $p=0.93$ ) or between rural and urban streams (rural: $\bar{X}=2.6 \pm 1.3$ species; range: $1-4$ species; urban: $\bar{X}=1.2 \pm 1.6$ species; range: $0-4$ species; $p=0.12$; Figure 8 ). However, rural ponds held significantly higher zygopteran species richness values $(\bar{X}=7.4 \pm 1.3$ species; range: 6-9 species) than urban ponds ( $\bar{X}=3.4 \pm 1.5$ species; range: $2-6$ species; $p=0.01)$ but did not 
differ significantly between rural and urban streams (rural: $\bar{X}=7.4 \pm 1.8$ species; range: 6-13 species; urban: $\bar{X}=5.8 \pm 1.1$ species; range: 4 -10 species; $p=0.32$; Figure 8 ).

Multiple environmental variables were measured for each study site (Table 12). The percent urban development surrounding urban and rural ponds ranged from 37.0 to $93.4 \%$, and 3.8 to $14.5 \%$ respectively. Most of that development consisted of open-space development (range for urban ponds: $1.0 \%$ to 21.6 ; rural ponds: 0.0 to $14.0 \%$ ), with lowintensity urban development covering a relatively small proportion of the area around ponds (Urban: 2.3 to $16.5 \%$; rural: 0.0 to $0.4 \%$ ). Urban and rural streams were surrounded by 36.9 to $100.0 \%$ and 0.0 to $26.0 \%$ urban development, respectively. Streams resembled ponds in that the development around them was primarily open development (urban: 8.7 to $96.2 \%$; rural: 0.0 to $15.4 \%$ ), with some low-intensity development (urban: 3.3 to $60.9 \%$; rural: 0.0 to $6.7 \%$ ).

Ponds and streams differed significantly in odonate community composition (twoway PERMANOVA; $p \leq 0.05$; Table 13). Pond communities clustered together but were distinct from stream communities along the first axis of an NMDS (Figure 9a). Pond communities of odonates differed significantly in urban versus rural sites (one-way PERMANOVA; $p=0.01$; Table 13 and Figure 9b). Stream communities also differed significantly in urban versus rural sites (one-way PERMANOVA; $p=0.03$; Table 13 and Figure 9c).

The environmental factors associated with the change in community composition within each ecosystem type generally differed, although distance to the urban center may have affected both pond and stream communities. For ponds, mean algal cover and distance to urban center were significant factors driving community composition (CCA; $p$ 
$\leq 0.04)$, and proportion of urban development approached significance $(\mathrm{CCA} ; p=0.07)$ (Table 14; Figure 10). These three factors together explained $45.4 \%$ of the variation in odonate community composition at ponds. Axis 1 of the CCA (Figure 10) depicts approximately half (49.4\%) of the variation explained by these three variables (eigenvalue: 0.3111 ), and a permutational ANOVA found this axis to be significant ( $p=$ 0.04). This axis appears to represent a rural-urban gradient as well as a gradient of algal coverage. Mean algal cover and proportion of urban development had positive correlations with Axis 1 (Table 14), and all of my urban sites clustered around the vector representing urban development (Figure 10a). Distance to urban center had a negative correlation with Axis 1 (Table 14). Axes 2 and 3 of the CCA were not significant ( $p \geq$ $0.13)$.

For stream community assemblages, the forward-step CCA found that only mean water temperature was significantly associated with community differences $(p=0.02$; Table 14; Figure 11). Distance to urban center approached significance $(p=0.06)$, but the proportion of urban development did not appear in the final model. Mean water temperature and distance to urban center explained $30.8 \%$ of the community diversity among the stream sites. Axis 1 depicts $63.6 \%$ of the variation in community assemblage explained by these two variables (eigenvalue: 0.4342 ) and was significant ( $p=0.03$ ); Axis 2 explained $36.2 \%$ of the variation explained by the two variables (eigenvalue: $0.2463)$, and approached significance $(p=0.06)$. Axes 1 and 2 reflect a water temperature gradient and an urban-rural gradient, with mean water temperature negatively correlated with Axis 1 and positively correlated with Axis 2, and distance to urban center positively correlated with both axes (Table 14). 
Indicator species analyses found select odonate species were indicators of ponds and streams in general and more specifically of urban versus rural ponds. After correcting for multiple testing, there were ten indicator species of pond ecosystems, all of which were anisopterans (Table 15). In contrast, the four species that were stream indicators were all zygopterans (Table 15). I found four indicator species (three Zygoptera and one Anisoptera) for rural ponds and one indicator (Anisoptera) for urban ponds, but no indicator species for rural or urban streams.

\section{DISCUSSION}

The effects of urbanization on species richness and community composition differed for dragonflies and damselflies and between ponds and streams. Urbanization altered pond damselfly species richness. However, urbanization did not alter damselfly species richness between urban and rural streams, and dragonfly species richness did not differ between urban and rural sites for either ponds or streams. Other researchers have noted that urban areas have the potential to maintain high levels of odonate diversity (Craves and O'Brien 2013; Goertzen and Suhling 2013; 2015; Ball-Damerow et al. 2014), but those species found in urban areas were often habitat generalists with strong dispersal abilities (Hill and Wood 2014). Habitat generality likely explains why dragonfly species richness did not significantly differ between urban and rural areas, as dragonflies are typically habitat generalists and strong dispersers (Corbet 1999; Heiser and Schmitt 2009; Monteiro-Júnior et al. 2014).

My analyses of indicator species also emphasize differences in the responses of dragonflies and damselflies to urbanization, as well as differences across ponds and 
streams. I identified indicator species for urban and rural ponds, but none for urban or rural streams. Further, my indicator species analyses found no damselfly indicators of urban ponds, yet found three for rural ponds. These findings highlight the sensitivity of lentic damselflies to urbanization. As habitat specialists, damselflies experience local extinctions in degraded areas more often than generalist dragonflies (Korkeamäki and Suhonen 2002). This difference, combined with their poorer dispersal capabilities (Clark and Samways 1996; Corbet 1999; Sahlén 2006; Heiser and Schmitt 2009) and a lack of connectivity among urban ponds, resulted in lower species richness at ponds in urban areas. I did not find a significant difference in zygopteran species richness between urban and rural streams because of the inherent connectedness of streams in both urban and rural settings, which reduces the likelihood of local extinction and allows for quicker recolonization should it occur.

The reduction in native vegetation, rather than increased levels of impervious surface cover, most likely affects odonate communities at urban ponds. The amount of urban development surrounding my pond sites ranged from 37.0 to $93 \%$, and at least half of the total urban development surrounding any urban pond was open development (51.1 to $92.3 \%$ of the total development) which consists of less than $20 \%$ impervious surface cover. The loss of the native vegetation surrounding bodies of water can influence odonate community assemblage, especially damselfly diversity and abundance (Remsburg and Turner 2009; Dutra and De Marco 2015), and likely alters predator-prey interactions for odonates and lowers environmental quality for some odonate species. Mowing can reduce the abundance of insects (Diehl et al. 2013), which would reduce prey availability for odonates (Baird and May 1997), and mowing can also increase 
predator pressure on odonates due to the loss of potential refuges from predators. Predation by birds became the leading cause for changes in herbivorous arthropod diversity in urban areas (Faeth et al. 2005), and while insectivorous avian species richness declines in urban areas, omnivorous species richness increases (Allen and O'Conner 2000; Kark et al. 2007). Due to the increase in omnivorous species, avian predation pressures on insects remain strong in urban areas. Additionally, tenerals (immature odonates that have recently emerged from an aquatic habitat) mature in the terrestrial vegetation surrounding lentic sites, and adults use this vegetation for roosting (Corbet 1999). In addition, Lee Foote and Rice Hornung (2005) found that a reduction in plant height from grazing negatively affected odonate diversity at wetlands and that the reduction in tall vegetation especially affected damselflies because the vegetation acted as a barrier to wind. Tall vegetation also creates shade, which damselflies need for thermoregulation (Monteiro-Júnior et al. 2013). The perception by odonates that grazed areas are degraded habitats exacerbates the reduction in odonate diversity (Lee Foote and Rice Hornung 2005). At my study sites, adult odonates possibly viewed the surrounding mowed areas and impervious surface cover as poor-quality habitat and continued to search for suitable habitat rather than reproduce at a poor-quality site.

In addition to urban development, mean algal cover also significantly affected pond communities. Mean algal coverage in a pond should correlate with impervious surface coverage, as increased impervious surface coverage leads to higher nutrient runoff into water bodies (Paul and Meyer 2001; Allan 2004), which results in higher amounts of algal coverage. This increase in nutrient levels can be especially detrimental to lentic systems where nutrients stay within the water body and are not carried 
downstream (Hassall 2014). In this study, some rural ponds also had high levels of algal coverage, possibly due to nearby agricultural fields or aeration of the rural ponds. Aeration prevents nutrients from settling to the bottom of the pond, thereby providing a constant source of nutrients for algal growth (Fast et al. 1973). Odonates use algal mats for perching and ovipositioning (Corbet 1999), and, for this reason, certain species prefer sites with high algal coverage, regardless of the amount of urbanization around the site. For example, Tramea sp. had the highest positive correlation with Axis 1 (Figure 10), which represented mean algal coverage and distance from urban center. This species occurred at both urban and rural sites (Table 11), suggesting this species prefers sites with high amounts of algal cover.

Distance to the urban center significantly predicted pond community composition and neared significance for predicting stream community composition. This factor broadly reflects the overall change in anthropogenic disturbance over distance without identifying specific elements of urbanization that might affect community compositions (Kinzig et al. 2005). Three of the species indicators for rural ponds, Enallagma basidens, Arigomphus villosipes, and Argia fumipennis, cluster near the distance variable in Figure 9, showing that the further a lentic site is from the urban center (e.g. the more rural the site), the more likely these species will be present. Interestingly, in my analysis of pond communities, the distance to the urban center did not correlate with the amount of urbanization around each site as obtained from the NLCD. Although frequently used to measure urbanization (e.g., Kinzig et al. 2005; Trammell and Carreiro 2011; Pardee and Philpott 2014), these two variables measure different aspects of urban development, resulting in differing outcomes (Raciti et al. 2012). 
For stream communities, only mean water temperature significantly predicted odonate community composition (Table 14; Figure 11). Urban streams tend to have high water temperature (Samways and Steytler 1996; Somers et al. 2013). However, in this study, an urban site recorded the coolest mean water temperature while a rural site held one of the warmest mean temperatures (Table 12). Samways and Steytler (1996) suggested that shade cover likely affected water temperature, which then significantly affected odonate community composition. They reasoned that cool lotic systems with much shade slowly warm up daily, and proper larval development possibly depends on warm water temperatures. Cool sites, urban or not, will host only those species whose larval stages tolerate cooler water temperatures. Water temperature affects egg development (Corbet 1999), and due to their tropical evolutionary history, odonates likely have high water temperature tolerances (Pritchard and Leggott 1987). Thus, the problem lies in cooler stream temperatures rather than warmer ones.

Inherent differences between pond and stream habitats likely affected how pond and stream communities respond to the same environmental factors. For example, mean algal cover did not significantly affect stream communities, and this lack of effect may be due to the fact that some of the problems unique to urban streams (e.g. increased flow disturbance) can counteract the increased nutrient loads that would encourage extensive algal growth (Walsh et al. 2005). Only one stream site, compared to eight pond sites, possessed over $5 \%$ algal cover. The difference in how many pond versus stream sites possessed high levels of algal cover suggests that water flow mitigates the effects of increased nutrient loads in the stream sites. 
In sum, due to inherent differences in lentic and lotic ecosystems and between dragonflies and damselflies, different environmental factors contribute to the taxonomic makeup of adult odonate communities at urban habitats, something not necessarily detected by species richness measurements alone. Urbanization altered community composition but not necessarily species richness, a pattern also found in odonates inhabiting deforested and forested streams (Monteiro-Júnior et al. 2013). This study thus confirms community composition provides more insight than species richness into how odonate communities respond to urbanization (Monteiro-Júnior et al. 2013); measuring species richness alone does not detect the homogenization of odonate communities that occurs in urban areas (Ball-Damerow et al. 2014). Focusing on species richness rather than community composition can lead to misinformed conclusions and ultimately, incorrect management practices (Fleishman et al. 2006).

Conservationists need to consider more than just the urban development when conserving or restoring freshwater systems in urban areas, and implement different management practices in the two types of ecosystems in order to conserve the highest diversity of odonates possible. The quality of habitat patches often determines insect diversity, and given the high mobility of odonates compared to many taxa, small efforts to improve urban ponds and streams for odonates could result in large gains in these sites' effectiveness as contributors to conserving odonate diversity. This study shows that different measurements of urbanization do not similarly reflect odonate communities, highlighting the need for the use of multiple variables measuring urbanization in conservation studies. 
My study focused on adult community assemblages, but lentic and lotic larval stages may show different responses to urbanization. Future studies should investigate the mechanisms driving the observed responses to urbanization to provide a basis for conservation efforts and assess whether adult and larval communities in urban areas respond similarly to urbanization. 
Table 10. List of pond and stream sites with their respective abbreviations, classifications, and geographic coordinates. Urban sites contain over $30 \%$ urban development within $150 \mathrm{~m}$ of the site. Urban development is determined from the four development categories of the National Land Cover Database.

\begin{tabular}{|c|c|c|c|c|c|}
\hline & Category & Site & Abbreviation & Coor & inates \\
\hline \multirow[t]{10}{*}{ Pond } & Urban & McNeely Lake & $\mathrm{ML}$ & $38^{\circ} 06^{\prime} 15^{\prime \prime} \mathrm{N}$ & $85^{\circ} 38^{\prime} 08^{\prime \prime} \mathrm{W}$ \\
\hline & & Waverly Pond & WA & $38^{\circ} 07^{\prime} 49^{\prime \prime} \mathrm{N}$ & $85^{\circ} 49^{\prime} 51^{\prime \prime} \mathrm{W}$ \\
\hline & & Iroquois Pond & IQ & $38^{\circ} 09^{\prime} 23^{\prime \prime} \mathrm{N}$ & $85^{\circ} 46^{\prime} 45^{\prime \prime W}$ \\
\hline & & Willow Pond & WI & $38^{\circ} 14^{\prime} 38^{\prime \prime} \mathrm{N}$ & $85^{\circ} 42^{\prime} 10^{\prime \prime} \mathrm{W}$ \\
\hline & & Chickasaw Pond & $\mathrm{CH}$ & $38^{\circ} 14^{\prime} 26^{\prime \prime} \mathrm{N}$ & $85^{\circ} 49^{\prime} 54^{\prime \prime} \mathrm{W}$ \\
\hline & Rural & Tom Wallace Lake & TW & $38^{\circ} 05^{\prime} 09^{\prime \prime} \mathrm{N}$ & $85^{\circ} 46^{\prime} 20^{\prime \prime} \mathrm{W}$ \\
\hline & & Private Pond & PP & $38^{\circ} 19^{\prime} 48^{\prime \prime} \mathrm{N}$ & $85^{\circ} 35^{\prime} 08^{\prime \prime} \mathrm{W}$ \\
\hline & & Lower Douglas Lake & LD & $37^{\circ} 49^{\prime} 20^{\prime \prime} \mathrm{N}$ & $85^{\circ} 52^{\prime} 36^{\prime \prime W}$ \\
\hline & & Jackson's Pond & JK & $38^{\circ} 11^{\prime} 56^{\prime \prime} \mathrm{N}$ & $85^{\circ} 32^{\prime} 05^{\prime \prime W}$ \\
\hline & & Angler Lake & AN & $38^{\circ} 13^{\prime} 52^{\prime \prime} \mathrm{N}$ & $85^{\circ} 27^{\prime} 59^{\prime \prime} \mathrm{W}$ \\
\hline \multirow[t]{10}{*}{ Stream } & Urban & Beargrass Creek & BG & $38^{\circ} 16^{\prime} 05^{\prime \prime} \mathrm{N}$ & $85^{\circ} 43^{\prime} 22^{\prime \prime} \mathrm{W}$ \\
\hline & & South Fork Beargrass Creek & SF & $38^{\circ} 12^{\prime} 46^{\prime \prime} \mathrm{N}$ & $85^{\circ} 42^{\prime} 44^{\prime \prime} \mathrm{W}$ \\
\hline & & Weicher Creek & WC & $38^{\circ} 14^{\prime} 20^{\prime \prime} \mathrm{N}$ & $85^{\circ} 38^{\prime} 06^{\prime \prime} \mathrm{W}$ \\
\hline & & Middle Fork Beargrass Creek & $\mathrm{MF}$ & $38^{\circ} 14^{\prime} 00^{\prime \prime} \mathrm{N}$ & $85^{\circ} 40^{\prime} 56^{\prime \prime} \mathrm{W}$ \\
\hline & & Clark Creek & $\mathrm{CL}$ & $38^{\circ} 12^{\prime} 52^{\prime \prime} \mathrm{N}$ & $85^{\circ} 43^{\prime} 36^{\prime \prime} \mathrm{W}$ \\
\hline & Rural & Popelick Creek & PL & $38^{\circ} 11^{\prime} 19^{\prime \prime} \mathrm{N}$ & $85^{\circ} 29^{\prime} 17^{\prime \prime} \mathrm{W}$ \\
\hline & & Floyds Fork & $\mathrm{FF}$ & $38^{\circ} 13^{\prime} 47^{\prime \prime} \mathrm{N}$ & $85^{\circ} 28^{\prime} 07^{\prime \prime} \mathrm{W}$ \\
\hline & & Wolf Pen Branch Creek & WP & $38^{\circ} 19^{\prime} 40^{\prime \prime} \mathrm{N}$ & $85^{\circ} 35^{\prime} 37^{\prime \prime} \mathrm{W}$ \\
\hline & & South Fork Harrod's Creek & $\mathrm{SH}$ & $38^{\circ} 20^{\prime} 23^{\prime \prime} \mathrm{N}$ & $85^{\circ} 31^{\prime} 41^{\prime \prime} W$ \\
\hline & & Otter Creek & OT & $37^{\circ} 55^{\prime} 48^{\prime \prime} \mathrm{N}$ & $86^{\circ} 01^{\prime} 45^{\prime \prime} \mathrm{W}$ \\
\hline
\end{tabular}


Table 11. List of species found at each site and abbreviations for each species name. See site name abbreviations in Table 10.

Tramea sp. includes T. onusta and T. carolina.

\begin{tabular}{|c|c|c|c|c|c|c|c|c|c|c|c|c|c|c|c|c|c|c|c|c|}
\hline \multirow[t]{2}{*}{ Dragonflies } & \multicolumn{10}{|c|}{ Ponds } & \multicolumn{10}{|c|}{ Streams } \\
\hline & $\mathrm{ML}$ & WA & $\mathrm{IQ}$ & WI & $\mathrm{CH}$ & TW & $\mathrm{PP}$ & LD & $\mathrm{JK}$ & AN & BG & SF & WC & $\mathrm{MF}$ & $\mathrm{CL}$ & $\mathrm{PL}$ & $\mathrm{FF}$ & WP & $\mathrm{SH}$ & OT \\
\hline Aeshna umbrosa (A) & & & & & & $\bullet$ & & & & & & & & & & & & & & \\
\hline Aeshna verticalis (B) & & & & & & • & & & & & & & & & & & & & & \\
\hline Anax junius (C) & • & & $\bullet$ & - & - & & $\bullet$ & & $\bullet$ & & & & & & & & & & & \\
\hline Anax longipes (D) & & & & & & & • & & & & & & & & & & & & & \\
\hline Arigomphus villosipes (E) & & & • & & & • & • & - & • & • & & & & & & & & & & \\
\hline Boyeria vinosa $(F)$ & & & & & & & & & & & & & & & & - & & & & \\
\hline Celithemis eponina ( $G$ ) & & & & & & & & & & • & & & & & & & & & & \\
\hline Celithemis fasciata $(H)$ & & & & & & - & & & & - & & & & & & & & & & \\
\hline Didymops transversa (I) & & • & & & & & & & & & & & & & & & & & & \\
\hline Dromogomphus spinosus (J) & & & & & & • & & & & & & & & & & & & & & \\
\hline Dromogomphus spoliatus (DE) & & & & & & & & - & & & & & & & & & & & & \\
\hline Dythemis velox $(K)$ & & & & & & & & & & • & & & & & & & $\bullet$ & & & \\
\hline Epiaeschna heros (L) & & & & & & & & & & & & & & & & & & $\bullet$ & • & \\
\hline Epitheca cynosura (M) & • & • & • & $\bullet$ & $\bullet$ & • & & & & & & & & & & & & & & \\
\hline Epitheca princeps (N) & • & • & • & • & & • & & • & • & • & • & & & & & & • & & & \\
\hline Erythemis simplicicollis (O) & • & - & - & • & • & • & $\bullet$ & & $\bullet$ & - & & & - & & & & • & & & • \\
\hline Gomphus graslinellus $(P)$ & & & & & & • & & • & & & & & & & & & & & & \\
\hline Hagenius brevistylus (AA) & & & & & & & & • & & & & & & & & & & & & \\
\hline Ladona deplanata (Q) & • & • & • & - & & • & $\bullet$ & & & & & & & & & & & & $\bullet$ & \\
\hline Libelulla incesta $(R)$ & • & • & • & • & & • & $\bullet$ & & $\bullet$ & - & & & & & & & & & $\bullet$ & \\
\hline Libelulla luctuosa (S) & • & • & • & • & - & • & $\bullet$ & - & $\bullet$ & - & & - & & & & & $\bullet$ & & & \\
\hline Libelulla pulchella $(T)$ & & & • & $\bullet$ & & & $\bullet$ & & & & & & & & & & & & & \\
\hline Macromia illinoiensis (U) & & & & & & & & & & & • & & & & & & & & & \\
\hline Pachydiplax longipennis (V) & • & • & • & • & • & • & • & & • & • & • & & & & & & & & & \\
\hline
\end{tabular}


Pantala flavescens (W)

Perithemis tenera $(X)$

Plathemis lydia $(Y)$

Sympetrum obtrusum (Z)

Tramea sp. (BC)

Tramea lacerata (EF)

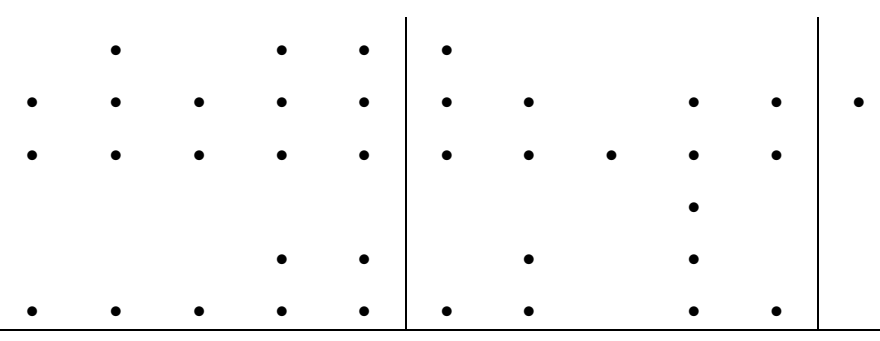

\begin{tabular}{|c|c|c|c|c|c|c|c|c|c|c|c|c|c|c|c|c|c|c|c|c|}
\hline \multirow[t]{2}{*}{ Damselflies } & \multicolumn{10}{|c|}{ Ponds } & \multicolumn{10}{|c|}{ Streams } \\
\hline & $\mathrm{ML}$ & WA & IQ & WI & $\mathrm{CH}$ & TW & PP & LD & JK & AN & BG & SF & WC & MF & $\mathrm{CL}$ & $\mathrm{PL}$ & $\mathrm{FF}$ & WP & $\mathrm{SH}$ & OT \\
\hline Argia apicalis (a) & $\bullet$ & & & & $\bullet$ & $\bullet$ & & $\bullet$ & & & $\bullet$ & & & $\bullet$ & & $\bullet$ & $\bullet$ & $\bullet$ & $\bullet$ & $\bullet$ \\
\hline Argia fumipennis (b) & & $\bullet$ & & & & $\bullet$ & $\bullet$ & $\bullet$ & $\bullet$ & $\bullet$ & & $\bullet$ & $\bullet$ & $\bullet$ & $\bullet$ & $\bullet$ & $\bullet$ & & $\bullet$ & \\
\hline Argia moesta (c) & & & & & & & & & & & & $\bullet$ & $\bullet$ & $\bullet$ & & $\bullet$ & $\bullet$ & $\bullet$ & $\bullet$ & $\bullet$ \\
\hline Argia sedula (d) & & & & & & & & $\bullet$ & & $\bullet$ & $\bullet$ & & & $\bullet$ & & $\bullet$ & $\bullet$ & & & \\
\hline Argia tibialis (e) & & & & & & & & & & & $\bullet$ & $\bullet$ & & $\bullet$ & & $\bullet$ & $\bullet$ & & & $\bullet$ \\
\hline Argia translata (f) & & & & & & & & & & & & & & & & & & $\bullet$ & $\bullet$ & \\
\hline Calopteryx maculata $(\mathrm{g})$ & & & & & & & & $\bullet$ & & & & & $\bullet$ & & $\bullet$ & $\bullet$ & $\bullet$ & $\bullet$ & $\bullet$ & $\bullet$ \\
\hline Enallagma aspersum (h) & & & & & & $\bullet$ & & & $\bullet$ & & & & & & & & & & $\bullet$ & \\
\hline Enallagma basidens (i) & & & & & & $\bullet$ & - & $\bullet$ & $\bullet$ & $\bullet$ & & & & & & $\bullet$ & & & & \\
\hline Enallagma civile (j) & $\bullet$ & & $\bullet$ & & & & & & & & & & & & $\bullet$ & & & & & \\
\hline Enallagma exsulans ( $k$ ) & & & & & & & & & & & $\bullet$ & $\bullet$ & $\bullet$ & $\bullet$ & & & & $\bullet$ & & \\
\hline Enallagma signatum (I) & $\bullet$ & & & & & & $\bullet$ & $\bullet$ & & $\bullet$ & & & & & & & & & $\bullet$ & \\
\hline Enallagma traviatum (m) & & & & & & $\bullet$ & $\bullet$ & & $\bullet$ & $\bullet$ & & $\bullet$ & & & & & & & & \\
\hline Hetaerina americana ( $n)$ & & & & & & & & & & $\bullet$ & & & & & & $\bullet$ & $\bullet$ & & & $\bullet$ \\
\hline Ischnura hastata (o) & $\bullet$ & & & & & & & $\bullet$ & & & & & & & & & & & & \\
\hline Ischnura posita (p) & $\bullet$ & $\bullet$ & $\bullet$ & $\bullet$ & $\bullet$ & $\bullet$ & $\bullet$ & & $\bullet$ & - & $\bullet$ & $\bullet$ & $\bullet$ & $\bullet$ & $\bullet$ & & $\bullet$ & & • & - \\
\hline Ischnura verticalis (q) & $\bullet$ & $\bullet$ & $\bullet$ & $\bullet$ & $\bullet$ & & $\bullet$ & $\bullet$ & $\bullet$ & $\bullet$ & $\bullet$ & & $\bullet$ & & & & & & $\bullet$ & \\
\hline Lestes congeners ( $r$ ) & & & & & & & & & & $\bullet$ & & & & & & & & & & \\
\hline Lestes rectangularis (s) & & & & & & & & & $\bullet$ & & & & & & & & & & & \\
\hline Lestes vigilax $(t)$ & & & & & & & & & $\bullet$ & & & & & & & & & & & \\
\hline
\end{tabular}


Table 12. List of environmental variables and the mean values of each variable used in my analyses. Dissolved oxygen was measured in microsiemens. Pond size and stream width were measured in meters. Development percentages describe the amount of urban development within $150 \mathrm{~m}$ of each site. Width of streams (in meters) was not used in any analyses.

\begin{tabular}{|c|c|c|c|c|c|c|c|c|c|c|}
\hline & & Site & $\begin{array}{l}\text { Distance } \\
(\mathrm{km})\end{array}$ & Size & $\begin{array}{c}\text { Development } \\
(\%)\end{array}$ & $\begin{array}{c}\text { Water } \\
\text { Temperature } \\
\left({ }^{\circ} \mathrm{C}\right)\end{array}$ & $\begin{array}{c}\text { Dissolved } \\
\text { Oxygen }(\mu \mathrm{S})\end{array}$ & $\begin{array}{c}\text { Emergent } \\
\text { Vegetation } \\
(\%)\end{array}$ & Alga (\%) & $\begin{array}{c}\text { Miscellaneous } \\
\text { Debris (\%) }\end{array}$ \\
\hline \multirow[t]{12}{*}{ Ponds } & Urban & $\mathrm{ML}$ & 21.1 & 18.7 & 37.0 & $28.7(0.3)$ & $205.5(56.1)$ & 44.6 (14.9) & $7.3(0.4)$ & 11.8 (3.9) \\
\hline & & WA & 15.4 & 1.7 & 42.3 & $29.9(2.7)$ & $138.05(55.6)$ & $12.2(3.3)$ & $6.8(11.7)$ & $5.9(5.2)$ \\
\hline & & IQ & 11.4 & 0.4 & 65.3 & $26.5(4.0)$ & $88.9(12.4)$ & 19.7 (6.9) & $5.2(5.3)$ & $8.1(6.8)$ \\
\hline & & WI & 5.8 & 1.9 & 73.0 & 28.9 (1.3) & $116.6(71.0)$ & 47.6 (11.5) & $5.9(8.5)$ & $8.7(2.8)$ \\
\hline & & $\mathrm{CH}$ & 6.4 & 0.3 & 93.4 & $27.2(6.9)$ & 26.95 (1.1) & 35.0 (19.6) & $27.7(7.7)$ & $17.5(10.5)$ \\
\hline & Mean & & $12.0(6.4)$ & $4.6(7.9)$ & $62.2(23.1)$ & $28.2(1.34)$ & $115.19(65.5)$ & $31.8(15.4)$ & $10.6(9.6)$ & $10.4(4.5)$ \\
\hline & Rural & TW & 19.3 & 2.2 & 3.8 & $28.3(1.9)$ & $119.7(19.8)$ & $14.4(8.2)$ & $3.4(4.1)$ & $26.7(23.3)$ \\
\hline & & PP & 17.7 & 0.8 & 4.2 & 26.7 (4.9) & $137.6(115.6)$ & 44.2 (19.9) & $17.5(20.1)$ & $17.0(5.7)$ \\
\hline & & LD & 49.7 & 28.1 & 6.9 & $29.6(1.7)$ & $112.3(2.8)$ & $8.5(4.3)$ & $0.6(0.8)$ & $6.1(4.6)$ \\
\hline & & $\mathrm{JK}$ & 22.4 & 0.4 & 9.7 & $26.0(1.5)$ & $63.2(49.0)$ & $39.5(29.5)$ & $18.3(16.4)$ & $6.3(3.1)$ \\
\hline & & AN & 26.4 & 1.2 & 14.5 & $29.0(2.6)$ & $104.1(9.8)$ & 33.4 (17.7) & $11.2(14.1)$ & $9.0(6.1)$ \\
\hline & Mean & & $27.1(13.0)$ & $6.5(12.1)$ & $7.8(4.4)$ & $28.0(1.5)$ & $107.4(27.6)$ & $28.0(15.7)$ & $10.2(8.0)$ & $13.0(8.8)$ \\
\hline \multirow[t]{12}{*}{ Stream } & Urban & $B G$ & 3.9 & 35.9 & 36.9 & $27.5(5.7)$ & $115.0(14.6)$ & $12.3(20.3)$ & $0.9(1.6)$ & $5.1(3.4)$ \\
\hline & & SF & 6.9 & 3.8 & 82.6 & $21.1(1.6)$ & $100.2(15.8)$ & $26.6(6.4)$ & $3.1(1.8)$ & 9.9 (1.9) \\
\hline & & WC & 11.6 & 10.4 & 100.0 & $22.7(1.4)$ & $115.4(20.2)$ & $4.8(6.9)$ & $0.2(0.1)$ & $12.5(7.5)$ \\
\hline & & MF & 7.6 & 13.5 & 100.0 & $23.3(2.2)$ & $128.3(25.0)$ & $4.8(3.6)$ & $9.4(8.9)$ & $4.5(3.9)$ \\
\hline & & $\mathrm{CL}$ & 6.1 & 1.6 & 100.0 & $18.2(1.1)$ & $93.1(8.3)$ & $3.3(3.2)$ & $0.5(0.9)$ & $9.9(2.9)$ \\
\hline & Mean & & $7.2(2.8)$ & $13.0(13.6)$ & $83.0(26.8)$ & $22.6(3.4)$ & 110.4 (13.9) & $10.4(9.7)$ & $2.8(3.8)$ & $8.4(3.5)$ \\
\hline & Rural & $\mathrm{PL}$ & 25.5 & 7.4 & 26.0 & $23.7(1.2)$ & $118.2(15.3)$ & $0.1(0.2)$ & $2.8(3.3)$ & $7.3(1.6)$ \\
\hline & & $\mathrm{FF}$ & 26.2 & 21.7 & 17.7 & $26.3(1.2)$ & $108.7(35.8)$ & $14.4(5.6)$ & $4.6(6.4)$ & $4.0(4.2)$ \\
\hline & & WP & 17.2 & 13.9 & 2.9 & $20.3(3.0)$ & $92.8(6.7)$ & $2.0(2.9)$ & $0.1(0.2)$ & $8.5(4.4)$ \\
\hline & & $\mathrm{SH}$ & 22.7 & 6.12 & 0.0 & $21.1(1.2)$ & 103.6 (12.7) & $3.1(3.5)$ & $3.4(5.7)$ & $5.3(6.7)$ \\
\hline & & OT & 42.3 & 20.7 & 0.0 & $22.5(3.0)$ & $141.4(0.2)$ & $35.8(16.1)$ & $0.6(1.0)$ & $5.2(3.7)$ \\
\hline & Mean & & $26.8(9.3)$ & $14.0(7.2)$ & 9.3 (11.9) & $22.8(2.4)$ & 112.9 (18.4) & 11.1 (14.9) & $2.3(1.9)$ & $6.1(1.8)$ \\
\hline
\end{tabular}


Table 13. A two-way PERMANOVA testing the effects of ecosystem type and development category on odonate community composition showed that ponds and streams differed significantly in odonate community composition (a). One-way PERMANOVAs showed that both pond (b) and stream (c) communities of odonates differed significantly in urban versus rural sites. Ecosystem = pond or stream; Development $=$ urban or rural.

\begin{tabular}{llccccc}
\hline & & Df & SS & F Model & $\mathrm{R}^{2}$ & P-value \\
\hline a) Ecosystem & Ecosystem & 1 & 1.808 & 10.058 & 0.325 & 0.000 \\
& Development & 1 & 0.490 & 2.726 & 0.088 & 0.020 \\
& Ecosystem*Development & 1 & 0.384 & 2.138 & 0.069 & 0.050 \\
& Residuals & 16 & 2.875 & & 1.000 & \\
& & & & & & \\
b) Pond & Development & 1 & 0.442 & 3.659 & 0.314 & 0.010 \\
& Residuals & 8 & 0.967 & & 1.000 & \\
& & & & & & \\
c) Stream & Development & 1 & 0.432 & 1.810 & 0.185 & 0.030 \\
& Residuals & 8 & 1.908 & & 1.000 & \\
\hline
\end{tabular}


Table 14. Forward-selection canonical correspondence analysis parameters for pond and stream systems and intraset correlations showing correlation of environmental factors with axes. For pond communities, mean algal cover and distance to urban center were significant factors driving community composition, and proportion of urban development approached significance $(\mathrm{CCA} ; p=0.07)$. For stream communities, only mean water temperature significantly predicted odonate community composition

\begin{tabular}{llcccc}
\hline & Environmental Factor & F Model & P value & AXIS 1 & AXIS 2 \\
\hline Pond & Mean algal cover & 1.91 & 0.04 & 0.84 & 0.39 \\
& Proportion of urban development & 1.42 & 0.07 & 0.53 & -0.82 \\
& Distance to urban center & 1.95 & 0.01 & -0.86 & 0.37 \\
& & & & & \\
\multirow{2}{*}{ Stream } & Mean water temperature & 1.57 & 0.02 & -0.79 & 0.61 \\
& Distance to urban center & 1.44 & 0.06 & 0.70 & 0.72 \\
\hline
\end{tabular}


Table 15. Indicator species for ponds versus streams and rural versus urban ponds. No species represented urban or rural stream systems. Indicator values represent the strength of a species being an indicator species.

\begin{tabular}{|c|c|c|c|c|}
\hline & Category & Species & Indicator Value & P-value \\
\hline \multirow[t]{14}{*}{ Ecosystems } & Pond & Tramea lacerata & 90.0 & 0.000 \\
\hline & & Libelulla luctuosa & 83.3 & 0.001 \\
\hline & & Pachydiplax longipennis & 81.0 & 0.001 \\
\hline & & Perithemis tenera & 81.0 & 0.001 \\
\hline & & Plathemis lydia & 76.9 & 0.003 \\
\hline & & Libelulla incesta & 71.1 & 0.007 \\
\hline & & Epitheca cynosura & 60.0 & 0.010 \\
\hline & & Anax junius & 60.0 & 0.012 \\
\hline & & Erythemis simplicicollis & 67.5 & 0.020 \\
\hline & & Epitheca princeps & 64.0 & 0.023 \\
\hline & Stream & Argia moesta & 80.0 & 0.001 \\
\hline & & Argia tibialis & 60.0 & 0.011 \\
\hline & & Enallagma exsulans & 60.0 & 0.011 \\
\hline & & Calopteryx maculata & 61.3 & 0.021 \\
\hline \multirow[t]{5}{*}{ Ponds } & Rural & Enallagma basidens & 100.0 & 0.007 \\
\hline & & Arigomphus villosipes & 83.3 & 0.047 \\
\hline & & Argia fumipennis & 83.3 & 0.048 \\
\hline & & Enallagma traviatum & 80.0 & 0.048 \\
\hline & Urban & Epitheca cynosura & 83.3 & 0.047 \\
\hline
\end{tabular}




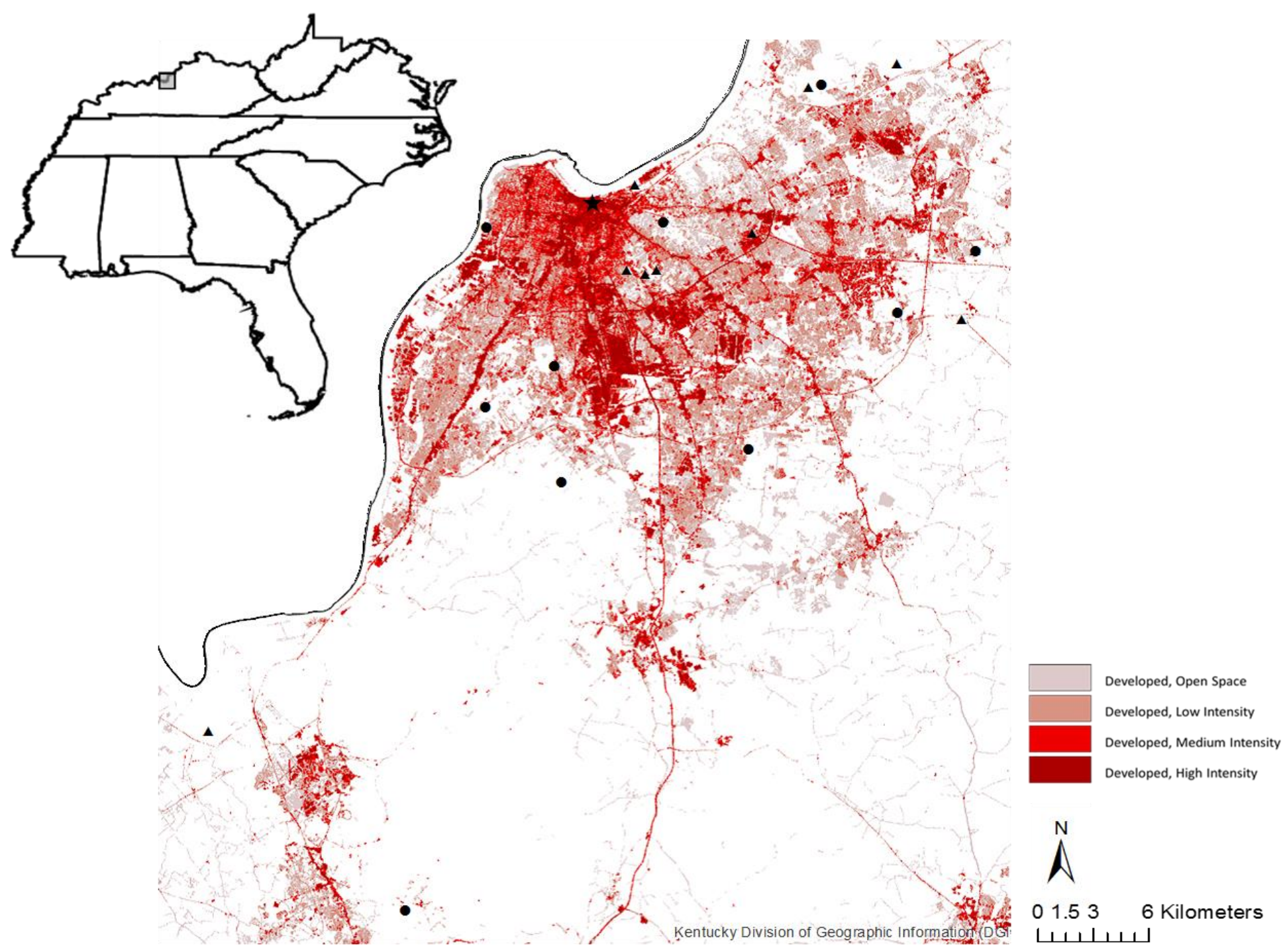

Figure 7. Map of sites. Filled circles indicate lentic sites, filled triangles indicate lotic sites, and the star locates downtown

Louisville. Development categories are based on the urban development classifications of the National Land Cover Database. 


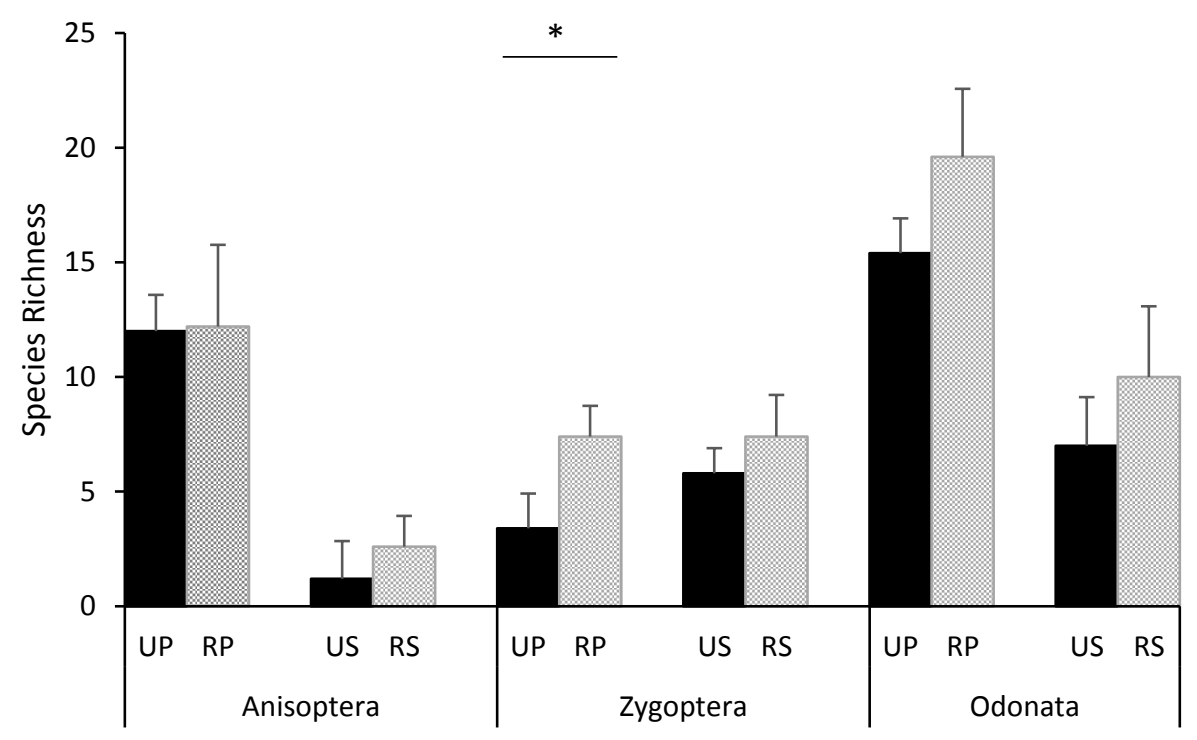

Figure 8. Mean species richness (standard deviation) of anisopteran, zygopteran, and all odonate species found in urban ponds (UP), rural ponds (RP), urban streams (US), and rural streams (RS). Each category includes five sites. Only zygopteran pond communities differed significantly $(*)$ between urban and rural sites. 


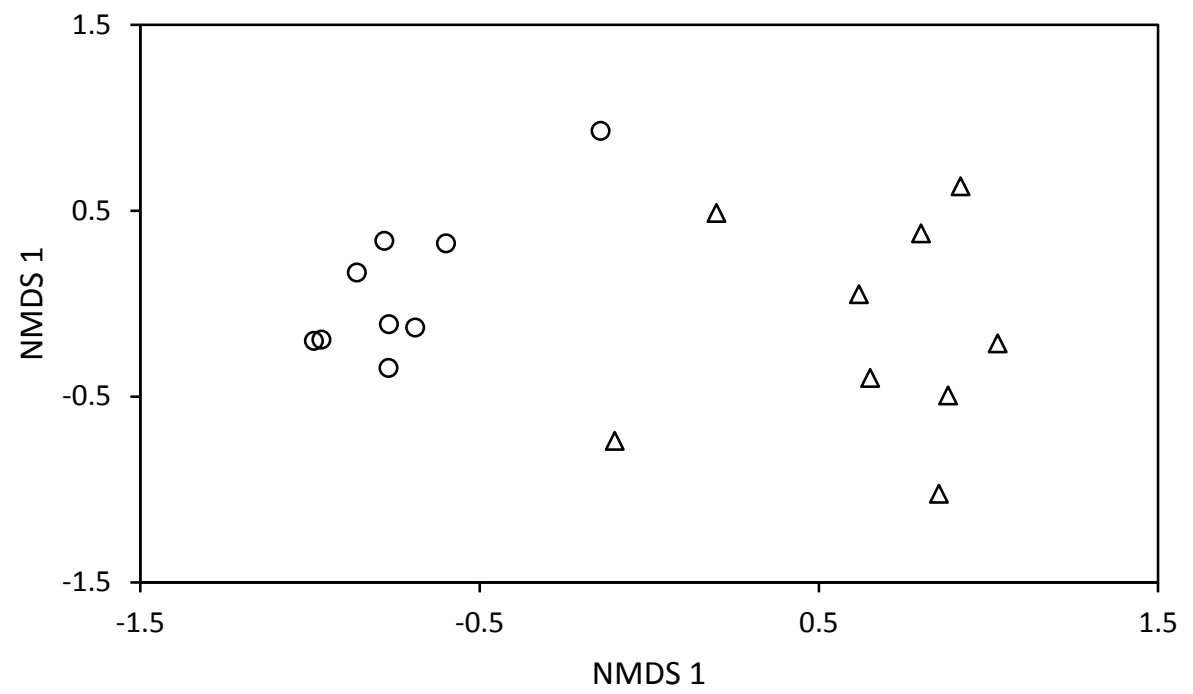

$9 b$

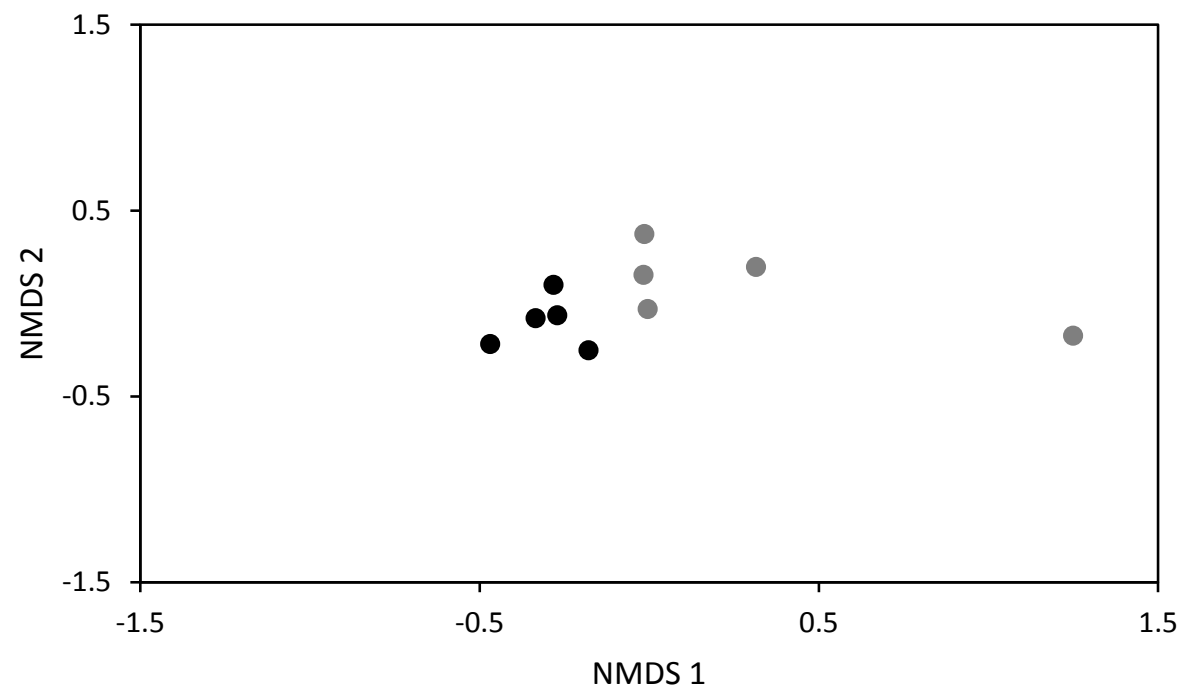




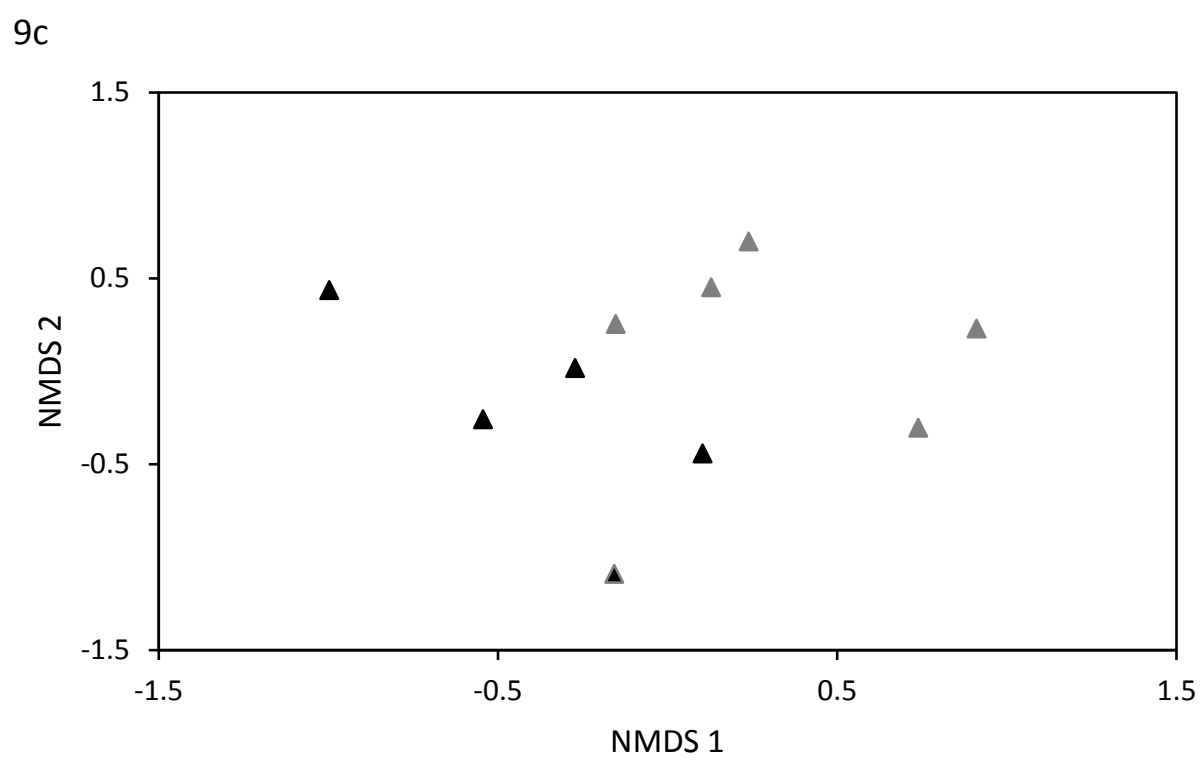

Figure 9. NMDS analysis showed that pond communities clustered together but were distinct from stream communities ( $\mathrm{a}$; stress $=0.13)$. Urban versus rural communities clustered separately at both ponds ( $\mathrm{b}$; stress $=0.07)$ and streams (c; stress $=0.09)$. Symbols: open circles, ponds; open triangles, streams; solid grey circles, rural ponds; solid black circles, urban ponds; solid grey triangles, rural streams; solid black triangles, urban streams. 


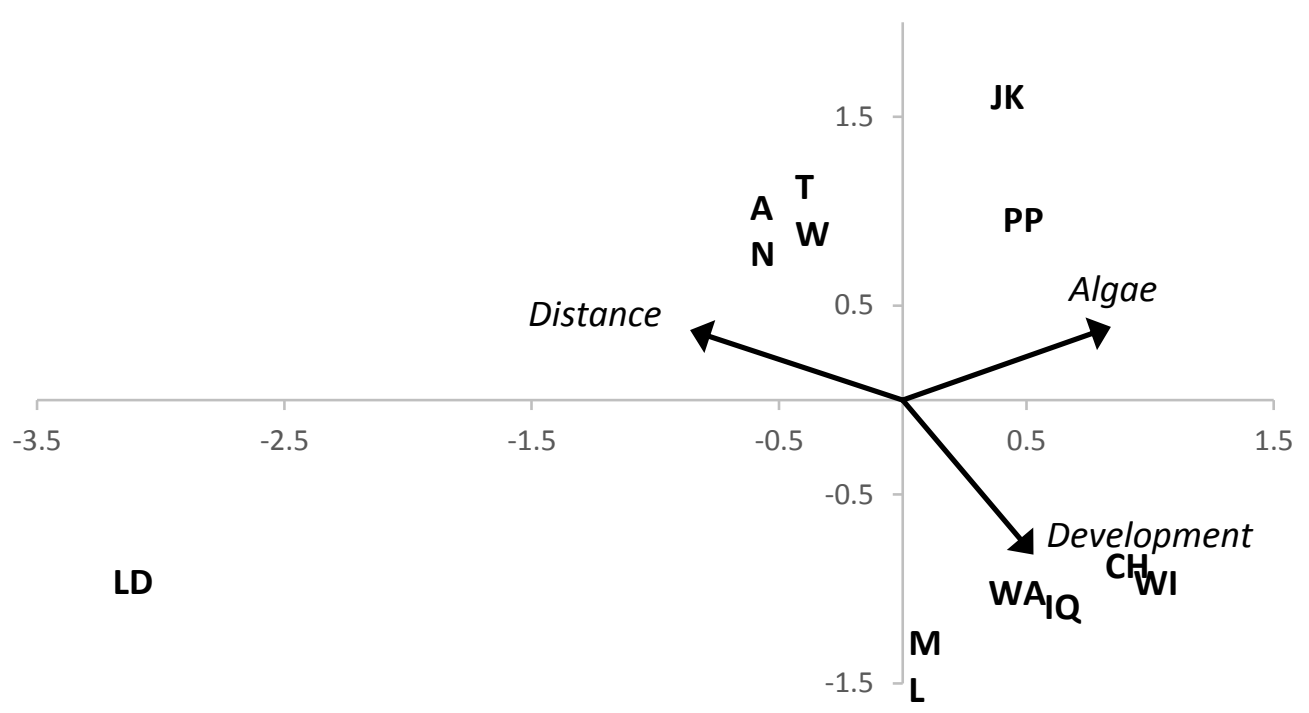

$10 \mathrm{~b}$

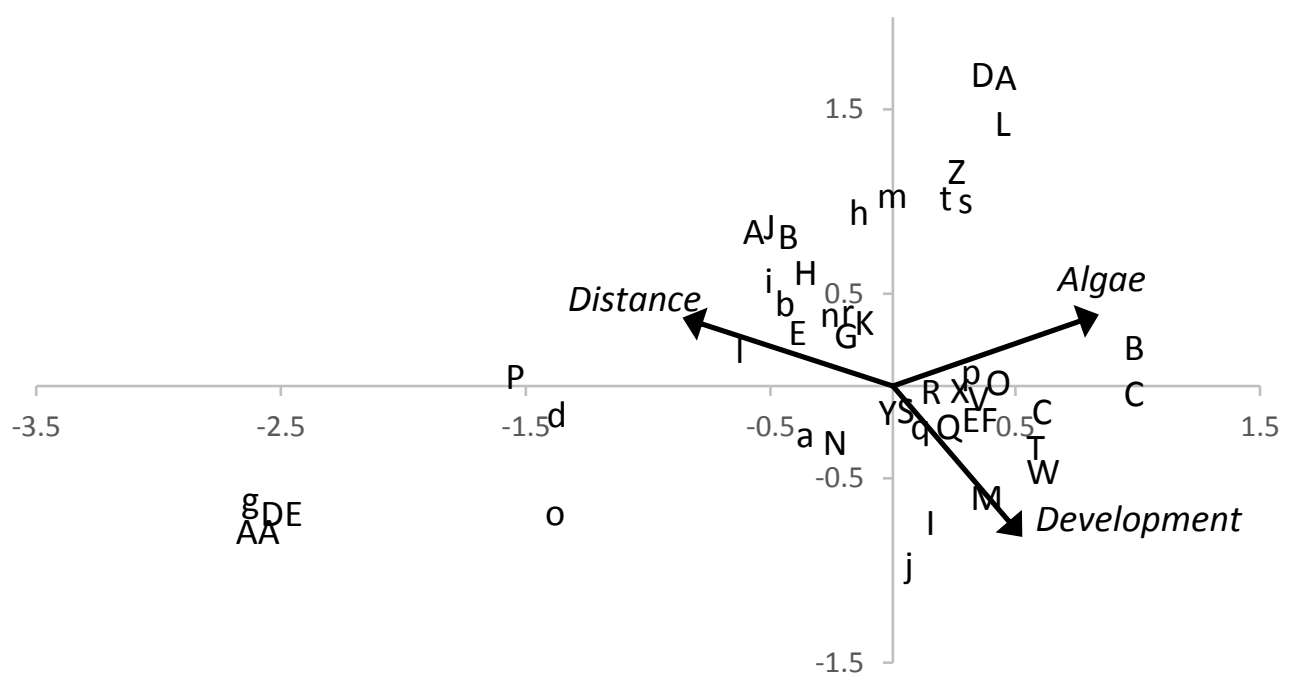

Figure 10. Plots of canonical correspondence analysis for pond communities showing sites (a) and species (b). Axis 1 represents a rural-urban gradient as well as a gradient of algal coverage and was significant. See Table 10 for site name abbreviations, which are in bold. See Table 11 for species name abbreviations. Environmental factor abbreviations: Distance $=$ distance to urban center; Algae $=$ mean algal cover; Development $=$ proportion of urban development. 

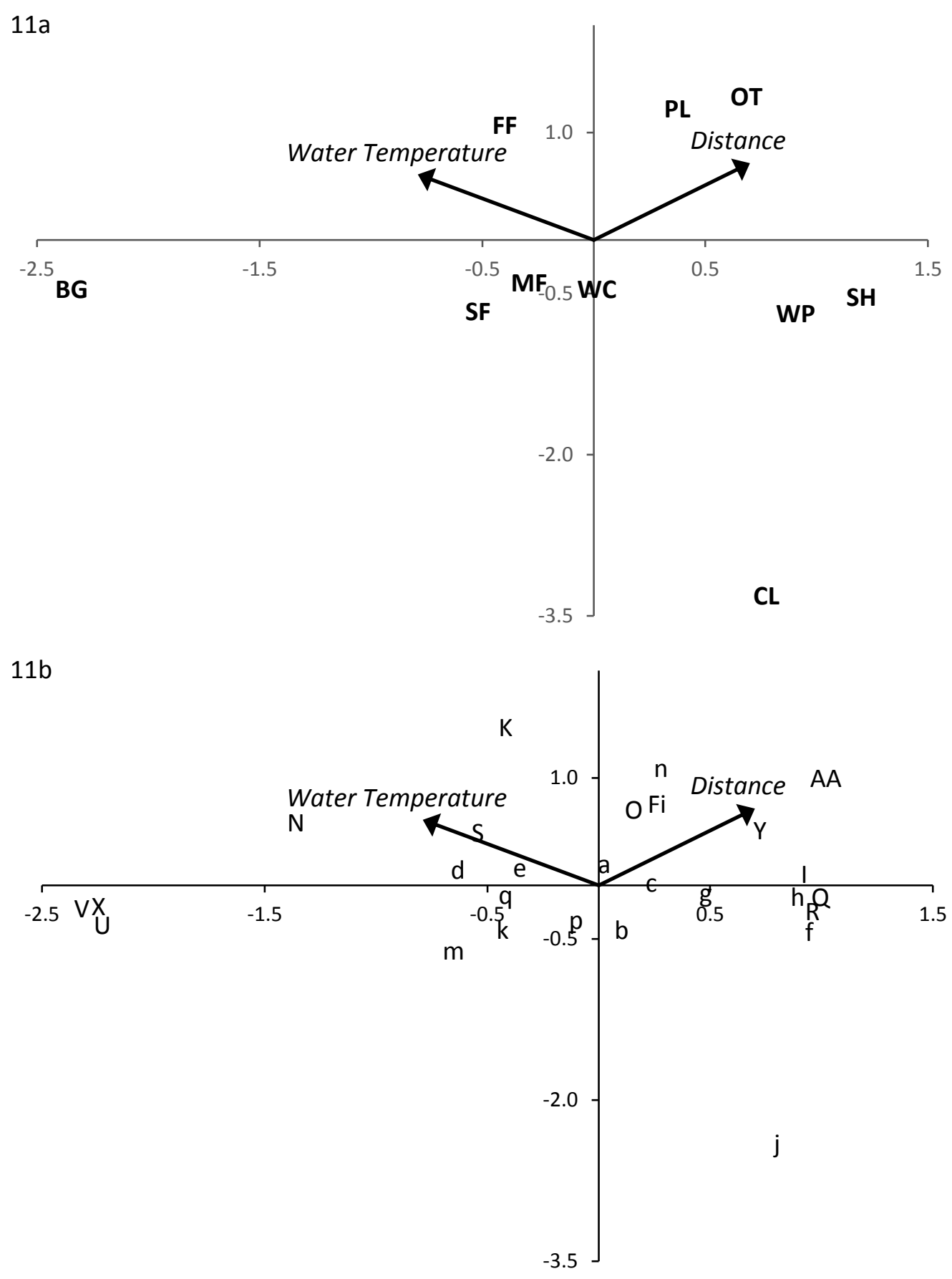

Figure 11. Plots of canonical correspondence analysis for stream communities showing sites (a) and species (b). The CCA found that only mean water temperature was significantly associated with community differences $(p=0.02)$, with distance to urban center approaching significance $(p=0.06)$. See Table 10 for site name abbreviations, 
which are in bold, and Table 11 for species name abbreviations. Environmental vectors:

Distance $=$ distance to $u r b a n$ center; Temperature $=$ mean water temperature. 
CHAPTER IV

DRAGONFLIES AND DAMSELFLIES HAVE DIFFERENT ECOLOGICAL CORRELATES WITH AN EXTINCTION RISK ASSESSMENT

\begin{abstract}
SUMMARY
Resilience against extinction is not uniform among taxa. Researchers need to be able to prioritize conservation concerns, and one effective approach is to identify species traits that correlate with extinction risk assessments. I tested for a correlation for three ecological traits (geographic range size, length of flight period, and habitat breadth) with an extinction risk assessment for North American odonates. Different traits showed different degrees of correlation with the assessment for anisopterans (dragonflies) and zygopterans (damselflies). Geographic range size and length of flight period correlated with assessments in both taxa, but dragonfly conservation rank also correlated with habitat breadth, and with the interactions between length of flight period and both geographic range size and habitat breadth. This research shows that even closely related taxa differ in their resilience to extinction, and that extinction correlates reflect interspecific variation in dispersal capabilities and voltinism among odonate taxa.
\end{abstract}




\section{INTRODUCTION}

Prioritizing conservation concern is a key aspect of conservation biology (Jeppsson and Forslund 2014) because the world is currently losing species at an increasing rate (Murray and Hose 2005). One important task is to develop cost-effective means of predicting which species are most at risk so that conservation efforts can be directed appropriately (O’Grady et al. 2004; Reynolds 2003; Murray and Hose 2005). Biota do not show uniform extinction risk (McKinney 1997; Fisher and Owens 2004; Cardillo et al. 2008) because variation in life-history traits within and among species cause differential responses of species to changes in the environment (Reynolds 2003). Differences in life-history traits can be correlated with extinction risk (McKinney 1997; Reynolds 2003; Hutchings et al. 2012; Jeppsson and Forslund 2014) and need to be identified across taxa and used to assess which species are most at risk (Foufopoulos and Ives 1998). Conservation priorities can then be established (Reynolds 2003; Jeppsson and Forslund 2014) and implemented (Nylin and Bergström 2009).

Our understanding of which invertebrate life-history traits and ecological factors correlate with extinction risk is currently poor (Reynolds et al. 2003) and with very high extinction rates among invertebrates (McKinney 1999), more efforts should focus on this group. In vertebrate species, which have been far more studied, factors such as geographic range size (Purvis et al. 2000; Jones et al. 2003; Murray and Hose 2005; Cardillo et al. 2005), body size (Bennett and Owens 1997; Murray and Hose 2005; García et al. 2008; Hutchings et al. 2012), and age at maturity (Bennett and Owens 1997; Webb et al. 2002; González-Suárez and Revilla 2013) correlate with extinction risk in a variety of both terrestrial and aquatic taxa. However, some invertebrate species do not 
express these traits in a measurable form. For example, certain life-history patterns such as long gestation (Purvis et al. 2000) and delayed maturity (Olden et al. 2008; Anderson et al. 2011) correlate with extinction risk in vertebrates, but these patterns are often not measurable in invertebrates. Further, extinction patterns in vertebrates do not necessarily mirror those in invertebrates (Clausnitzer et al. 2009). Thus, unique ecological correlates in invertebrates are needed to best prioritize conservation effects.

I examined whether three species traits-geographic range, mean length of flight season, and habitat breadth correlate with extinction risk in odonates with ranges including the contiguous states of the USA or Alaska. I examined species inhabiting the United States because the basic ecology of these species is well documented, which is not the case for many species found solely in Mexico. Geographic range is likely to be a strong correlate of extinction risk across all biota (Gaston 1994; Gaston and Fuller 2008; Hanna and Cardillo 2013), and research on vertebrates supports this idea (e.g. Purvis et al. 2000; Jones et al. 2003; Murray and Hose 2005; Cardillo et al. 2005; Hanna and Cardillo 2013). Species with large ranges should have a reduced likelihood that a single environmental event will eliminate all individuals, and if local extinction occurs, then the species will persist in and potentially recolonize other areas (Brook et al. 2008). However, research predominately focuses on vertebrates and is less known for invertebrates (Korkeamäki and Suhonen 2002; Nylin and Bergström 2009; McCauley et al. 2013). With the world currently undergoing its sixth mass extinction (Barnosky et al. 2011), we need to understand whether geographic range currently affects extinction risk in other invertebrates, such as freshwater species. 
The length of the flight period may be correlated with extinction risk in odonates as well as other flying insects for several reasons. First, length of the flight season likely correlates with dispersal ability in invertebrates; species with stronger dispersal abilities should be better at finding suitable habitat than those with weak dispersal abilities (Sullivan et al. 2000). Second, the length of flight season possibly reflects "fast-slow" life history patterns such as length of adult stage and voltinism (number of generations produced in a year). Species with longer flight periods should have longer adult stages (Mattila et al. 2008; Jeppsson and Forslund 2014), and as is the case in vertebrates (Webb et al. 2002; Morrison and Hero 2003) the length of the adult life stage should affect extinction risk in invertebrates because it is positively correlated with the number of reproduction events (Morrison and Hero 2003). Finally, length of flight period can also affect voltinism, with a longer flight season allowing more than one generation to reproduce and resulting in greater annual fecundity for multivoltine species. Multivoltinism is correlated with lower risk of extinction in longhorn beetles (Jeppsson and Forslund 2014). The length of the flight season correlates with extinction risk in several insect taxa with winged adults, including beetles (Jeppsson and Forslund 2014), hoverflies (Sullivan et al. 2000), and butterflies (Kotiaho et al. 2005) and moths (Mattila et al. 2008). Because odonates possess relatively strong dispersal capabilities and show interspecific variation in voltinism, length of flight season likely correlates with odonate extinction risk.

The number of habitats a species occupies has also been found to correlate with extinction risk (Fisher and Owens 2004). Species that occupy only a low number of habitat types are at a higher risk of extinction because the degradation or loss of any of 
these habitats can have a great impact on species persistence (Rabinowitz 1981). Conversely, a species occupying a large variety of habitats can still persist if one of those habitat types is destroyed. As with geographic range, vertebrates that occupy fewer habitat types are more at risk (e.g. Hutchings et al. 2005; Foufopoulos and Ives 1999; García et al. 2008). The number of habitats occupied is a measure of habitat specialization (Fisher and Owns 2004) and ultimately niche breadth (McKinney 1997), with the degree of habitat specialization increasing as the number of habitats occupied decreases. One would thus expect that the negative relationship between number of habitats occupied and extinction risk would also be seen across invertebrates. However, previous studies have not shown a clear pattern for invertebrate species. Extinction risk was not significantly affected by the number of habitats a species occupied in hoverflies (Sullivan et al. 2000) or butterflies (Nylin and Bergström 2009), but was affected by habitat specialization in beetles (Davies et al. 2004) and dragonflies (Korkeamäki and Suhonen 2002). One reason for this ambiguity may be due to the level at which habitat specialization is measured. In both studies in which habitat specialization was a significant predictor of extinction risk, habitat specialization was a qualitative measurement (e.g. habitat generalist versus specialist) rather a quantitative one, whereas in the studies in which specialization was not significant, the factor was measured as the number of habitats occupied.

I chose the order Odonata as my focal group because they are generally wellstudied, and the group is relatively speciose and diverse. Further, odonates are considered bioindicators of ecosystem health (Corbet 1999) and are well studied in North America. These final two criteria make them excellent candidates for studying extinction 
threats (McKinney 1999). Two previous studies examined the relationship between odonate life-history traits and extinction risks, but at very different geographic scales. Clausnitzer et al. (2009) performed a global assessment of odonates and identified which geographic areas and broad habitat types (e.g. lentic or lotic, forest or shrubland) correlate with at-risk odonate species, and Korkeamäki and Suhonen (2002) found that geographic distribution and habitat specialization affect the local extinction of 20 odonate species in Finland. However, Nylin and Bergström (2009) found that extinction patterns among butterflies in Sweden differed from the patterns found among butterflies across all of Europe, cautioning that it may be difficult to generalize extinction patterns of a taxon at different geographical scales.

\section{METHODS}

\section{Data Collection}

Using a variety of sources ranging from books (Westfall and May 1996; Needham et al. 2000; Manolis 2003; Abbott 2005; Paulson 2009; Paulson and Dunkle 2009; Paulson 2011) to online databases (NatureServe Explorer 2009) I collected information regarding the extinction risk assessment, habitat specificity, geographic distribution, and flight seasons of all odonate species inhabiting the United States, with the exception of species endemic to Hawaii. I chose to obtain information from multiple sources to gain the most comprehensive and accurate list possible. Extinction risk in this study is ranked according to the global conservation status ranking system developed by NatureServe Explorer (2009). I used the global conservation status rather than the national 
conservation status because some of my species ranges included Canada and Mexico and some species with small ranges in the United States had large ranges in Mexico. Species are assigned by NatureServe to one of five global conservation statuses using a weighted, standardized calculator that takes into consideration rarity, trends in population size, and threats to species persistence (Faber-Langendoen et al. 2009). Conservation statuses are ranked from G1 to G5, with G1species considered critically imperiled and G5 species considered secure. Species given a status of two sequential ranks (e.g. G3G4) by NatureServe Explorer (2009) were adjusted to the lower rank for my analyses. Species given two non-sequential ranks were assigned the intermediate rank; for example, a species ranked as G1G3 would be given a G2 ranking. I excluded 26 species from this study because of missing or questionable information about them. Four species for which insufficient data were available were not given a conservation status by NatureServe (2009), and seventeen species were listed as inhabiting the United States in other sources but not by NatureServe (2009). The remaining five species I eliminated were listed as inhabiting the United States by NatureServe (2009) but not by any other source (and no information on habitat occupancy was provided by NatureServe or any other source). As a measure of geographic distribution, I determined the number of American states, Canadian provinces (hereafter states), and Mexican states each species inhabits. I chose not to include Hawaii or island countries because of the inherently limited geographic distribution that may occur as a result of a species being endemic to an isolated island. I obtained geographic distributions within the United States and Canada via NatureServe Explorer (2009), and Mexican distributions were inferred from Paulson (2009, 2011). Distributions on NatureServe were cross-checked with Paulson (2009, 
2011). Due to the wide range of size among the states included in my study, I combined certain small states and analyzed them as a single state. In Canada, I combined Prince Edward Island and Nova Scotia; in the United States, I combined Connecticut, Rhode Island, Massachusetts, Vermont, and New Hampshire into one state and Washington DC, Delaware, Maryland, and New Jersey into another. In Mexico, states were combined as follows: Mexico City, Mexico, and Hidalgo; Puebla, Tlaxcala, and Morelos; Guanajuato and Queretaro; Zacatecas and Aguascalientes; Colima and Jalisco. Thus, the maximum number of states and provinces across which a species could range is 81 . NatureServe listed 3 species as having disconnected ranges, with sightings in Rhode Island but all other sightings more than $500 \mathrm{~km}$ distant. The Rhode Island occurrences for these species were disregarded as they were not also listed in Paulson $(2009,2011)$.

I determined the average flight season length (measured in months) per state of each species using information from Paulson $(2009,2011)$. These sources provided the most comprehensive information regarding flight season for each species of all the sources from which I obtained habitat occupancy information. However, these two field guides present flight seasons within the United States and Canada only. I did not factor flight seasons in Mexico into my analyses because this information was only rarely and sporadically given in any source and not included in Paulson $(2009,2011)$ at all. To remove the effect of latitudinal range on flight season, I calculated each species' average flight season length per state/province and used these values in my analyses.

To assess the habitat breadth of each species, I collected information on the types of aquatic systems each species inhabits (e.g. ponds, streams, rivers, lakes; Table 16) and the speed of the water body (still, slow, intermediate, fast). Lotic sites described as 
having "some current" were classified as having an intermediate flowing speed. I did not consider substrate type in my analyses because this information was not consistently provided for all species. To quantify the number of habitats occupied by each species, every descriptor was given a single point, and all points were summed together. I used this method to reflect the idea that a species can occupy a greater diversity of habitats both by occupying a larger number of habitat types, and in the case of lentic species, flow speeds.

\section{Statistical Analyses}

I performed statistical analyses separately for zygopterans (damselflies) and anisopterans (dragonflies). Due to a low number of G1 and G2 species, I combined G1 (if present), G2, and G3 species into a single group (“At-risk” group), resulting in three response categories: "At-risk", G4, and G5. I performed an ordinal logistic regression because my response variable (global conservation status) was an ordered, discrete variable and my explanatory variables were a mixture of count data (habitat specificity and geographic distribution) and continuous data (average flight season per month). I first tested for heteroscedasticity among my variables using the gvlma function in the $\mathrm{R}$ package gvlma v. 1.0.02 (Pena and Slate 2006). I detected significant levels of heteroscedasticity between geographic distribution and both habitat occupancy and average flight season for anisopterans. To correct this, I used the MASS package v. 7.345 (Venables and Ripley 2002) to identify lambda from a Box-Cox transformation. Lambda values were similar to correct heteroscedasticity between geographic distribution 
and both habitat occupancy and average flight season ( 0.414 and 0.444 , respectively), so I transformed geographic range values as $\mathrm{x}^{0.43}$ to remove significant heteroscedasticity. All zygopteran predictor variables were heteroscedastic. I tested for collinearity among the variables and the interactions of the variables using the package car (v.2.0-20, Fox and Weisberg 2011). Because all variables and their interactions were highly collinear for both anisopterans and zygopterans, I performed a standardized transformation on each variable using the equation: $\left(\frac{1}{\sqrt{n-1}}\right)\left(\frac{x-\bar{x}}{S D}\right)$. Because a one unit change in the original data is different than a one unit change in the transformed data (which is used in the interpretation of odds ratios), I then scaled the data using the R package plyr v. 1.8.3 (Wickham 2011) to ensure that the calculated values (e.g., odds ratios) were at a relevant scale.

I used forward-selection ordinal logistic regressions (Allison 1999) using the polr function in the MASS package to determine which of the three explanatory variables and their interactions were associated with global conservation status within each suborder. I tested for overdispersion by dividing the residual deviance of the chosen model by the residual degrees of freedom and by a chi-square goodness-of-fit test. All statistical analyses were performed using the statistical software R v 3.1.1 (R Core Development Team 2015). All means were reported with standard deviation.

\section{RESULTS}

A total of 435 species (306 anisopteran and 129 zygopteran) from 12 families (seven anisopteran and five zygopteran) were documented and examined in this study. I found six G1 species (all anisopteran), 15 G2 species (11 anisopteran and four 
zygopteran), 34 G3 species (27 anisopteran and seven zygopteran), 104 G4 (73

anisopteran and 31 zygopteran), and 276 G5 species (189 anisopteran and 87

zygopteran). Table 17 lists the number of anisopterans and zygopterans found in each conservation rank. In anisopterans, geographic range size ranged from 1 to 76 states (19.44 \pm 13.04$)$, average flight period ranged from 0.6 to 12 months $(4.30 \pm 1.85)$, and habitat occupancy values ranged from 1 to 13 habitats (5.04 \pm 2.24$)$. Zygopteran geographic range size ranged from 1 to 75 states $(23.23 \pm 15.92)$, average flight season per state ranged from 1 to 12 months (5.87 \pm 2.26$)$, and habitat breadth ranged from 1 to 12 habitats $(5.45 \pm 2.35)$. Table 18 lists mean values for habitat specificity, geographic distribution, and average flight season for each conservation status within anisopterans and zygopterans.

Conservation statuses of anisopterans and zygopterans were differently affected by life history traits. For anisopterans, the best-fitting ordinal logistic regression model included geographic range, length of flight period, habitat breadth, geographic range $\mathrm{x}$ length of flight period, and habitat breadth x length of flight period (AIC: 346.16, residual deviance: 332.16, residual degrees of freedom: 299). All variables and interactions included in this model were significant (Table 19). Overdispersion was only moderate (1.15) and not significant $\left(\mathrm{X}^{2}\right.$ test, $\left.p=0.09\right)$.

The odds ratios describe how a species' conservation status changes as a one-unit change in a predictor variable occurs (Table 20). The parameter value for the interaction between geographic range and length of flight period was negative, indicating that as the geographic range increased, the effect of length of flight season on extinction risk decreased. Because the odds ratio for the geographic range $\mathrm{x}$ average length of flight 
period interaction was 0.48 , which was less than 1 , the likelihood of a species transitioning from "At-risk" to G4 or G5 with a one unit increase in this interaction term decreased.

For zygopterans, the best-fitting model included geographic distribution and average length of the flight season (AIC: 135.90, residual deviance: 127.90, residual degrees of freedom: 125; Table 18). Over-dispersion was moderate and not significant (0.94, $\mathrm{X}^{2}$ test, $\left.p=0.41\right)$. The odds ratios of both geographic distribution and length of flight season were both above a value of 1 , indicating that a one unit change in either category increased the likelihood that a species moves from the "At-risk" rank to a G4 or G5 rank (Table 19). Increasing the geographic distribution of a species by one state increased the odds that the species was a G4 or G5 rank by 21.32 fold (Figure 1). Increasing the length of a species' flight period by one month increased the odds that the species was a G4 or G5 by 1.64 (Figure 2).

\section{DISCUSSION}

Geographic range and length of flight period affected assessed risk of extinction in both damselflies and dragonflies. In dragonflies, interactions between length of flight period with geographic range and with number of habitats occupied also affected extinction risk. These results show that ecological correlates can vary even among closely related taxa. More complex correlations with extinction risk exist in dragonflies than in damselflies. This research not only contributes to the growing support for the use of ecological correlates in identifying species most at risk of extinction but identifies a 
unique (length of flight season) ecological correlate with odonate extinction risk at the continental scale.

Geographic range size is driven by dispersal capability and is positively correlated with various measurements of wing size in damselflies (Rundle et al. 2007; Swaegers et al. 2014) and with odonate dispersal behavior (McCauley et al. 2014). Odonates possess strong dispersal abilities relative to other animals (Corbet 1999; Clausnitzer et al. 2009), but McCauley et al. (2013) found that of 15 North American dragonfly species, those with smaller ranges were less likely to recolonize an area after local extinction occurred. In general, species characterized as having strong dispersal capacities will be able to sample several habitats before selecting the one of highest quality (Pulliam and Danielson 1991). Thus, if a large geographic range indicates that a species avoids regions of unsuitable habitat and recolonizes areas where local extinction has occurred, then clearly the risk of extinction should decrease.

Length of flight period may also be positively correlated with dispersal capability (Grewe et al. 2012), although evidence is more equivocal. A short flight season may reflect low dispersal abilities in hoverflies (Sullivan et al. 2000), and butterflies with low dispersal abilities and shorter flight periods had higher risk of extinction (Kotiaho et al. 2005). However, Powney et al. (2015) found that the likelihood of persistence of odonates across Britain and Ireland over the past 30 years increased with shorter flight periods not longer periods, and they reasoned that length of flight period was not a suitable measure of dispersal ability.

Length of flight period could also be a surrogate measure of reproductive opportunities. A longer adult stage might indicate that individuals have more 
opportunities to mate and reproduce (Öckinger et al. 2010; Grewe et al. 2012), reducing the risk of population extinction (Henle et al. 2004). At the species level, length of the flight period also reflects the different adaptive strategies in species. Many odonate species are multivoltine Corbet et al. (2006), a trait that allows for resilience to environmental changes (Diaz et al. 2008). For example, climate change caused earlier than normal spring time emergence of odonates (Hassall et al. 2007), and for multivoltine species, only the first generation would be exposed to any detrimental effects of an early emergence time (Knell and Thackeray 2016), with subsequent generations of the same season potentially able produce enough offspring to counteract any population declines in the first generation (Knell and Thackeray 2016). If a longer flight season reflects more generations per year, as evidence suggests in lepidopterans (Kitahara and Fujii 1994; Roy and Sparks 2000; Nylin and Bergstrom 2009; Altermatt 2010), then multivoltine species may more quickly recover from changes or disturbances in the environment (Knell and Thackeray 2016). This same concept can be applied to univoltine species that have staggered emergence times, which would similarly lengthen the flight period (Zonneveld et al. 2003; Komonen et al. 2004). A population that has individuals overwintering at different instar stages will have staggered emergence times (Paulson and Jenner 1971); this temporal variation in emergence would allow for the utilization of optimal environmental conditions or avoidance of a catastrophic event (Neal et al. 1997) by at least some of a population.

I found a significant negative interaction between geographic range size and length of flight season in dragonflies but not in damselflies. Corser et al. (2015) found that damselflies with longer flight periods also had larger geographic ranges across the 
state of New York, and while I found that damselfly species with a low risk of becoming extinct had wider niche breadths and longer flight periods, the interaction between the two factors did not correlate with extinction risk assessment. In my study, I also found that increasing the geographic range of a species can mitigate the impact a short flight season has on a species' extinction risk, and vice versa. Because both geographic range size and length of flight period reflect dispersal capacities, strong dispersers would quickly reach other suitable habitat in a short amount of time or have plenty of time to reach suitable habitat that is far away. Or, a wide geographic range would decrease the likelihood that catastrophic event eliminated all adults of species with short flight seasons.

Habitat breadth significantly correlated with extinction risk assessment, but only in dragonflies. Habitat generalists had broader regional occurrences across Nevada and California across the past century (Ball-Damerow et al. 2014), so I expected to find this same pattern. However, the number of habitats occupied was not significantly correlated with extinction risk in damselflies, a pattern also found in hoverflies. For hoverflies, the number of habitats occupied may not accurately reflect niche breadth, and host plant type might be a more accurate correlate (Sullivan et al. 2000). Damselflies may be showing an analogous pattern with types of habitats occupied. Habitat type correlates with extinction risk (Korkeamäki and Suhonen 2002; Clausnitzer et al. 2009; Suhonen et al. 2014), and so habitat type may be a more accurate reflection of extinction risk across both dragonflies and damselflies. Surprisingly, Suhonen et al. (2014) found that odonate specialists had lower local extinction rates than generalists. Further studies are needed to better identify how habitat breadth affects odonate extinction risk. 
Dragonfly extinction risk assessment significantly and positively correlated with the interaction between habitat breadth and the length of flight period. Komonen et al. (2004) found a significant correlation between length of flight period and habitat breadth in butterflies. They reasoned that habitat specialists would have shorter flight seasons due to habitat generalists being able to tolerate a wide variety of environmental conditions and thus able to tolerate changes in the environment. In my study, all 28 dragonfly species that utilize temporary habitats ranked as G5 species, and likely exhibit a multivoltine strategy because of the short generation time required to successfully inhabit temporary habitats (Corbet et al. 2006).

I found significant differences in how species' traits affect extinction risk in dragonflies and damselflies. Surprisingly, the differences were found despite the fact that there are no differences in the mean values of the three ecological correlates within each conservation rank between dragonflies and damselflies across ranks. These differences are possibly the result of the low number of at-risk damselflies found across North America. Increasing the number of damselflies included in this study could reveal ecological correlates with extinction that align more with those found in dragonflies. However, it is also possible that the differences I observed are true differences due to species-specific trait variations (McCauley et al. 2014).

The contrasting findings of my study versus those of other odonate studies suggest that geographical scale is also an important factor when identifying ecological correlates with extinction risk, as has been found in butterflies (Nylin and Bergstrom 2009). Corser et al. (2015) found a significant correlation between the length of flight period and geographic range size in damselflies in the state of New York, while my study 
was across the contiguous United States, Mexico, and Canada. Further, geographic distribution was found to be a significant predictor of regional extinction in Finland (Korkeamäki and Suhonen 2002), indicating that the use of geographic range is a correlate of extinction risk at larger landscape levels. McCauley et al. (2014) noted that geographic scale was a likely reason for the contrasting results between their study and others.

While the overall number of at-risk odonates across North America is fairly low, my study nonetheless contributes to the growing number of comparative studies that identify ecological correlates with extinction risk. The significant effects of flight period length in this study show that more studies of invertebrates need to be conducted in order to identify predictors of extinction risk that better reflect their life history traits and patterns. 
Table 16. List of documented aquatic systems inhabited by odonates in my analyses.

\begin{tabular}{l}
\hline \multicolumn{1}{c}{ System } \\
\hline Seep \\
Garden Pond \\
Pool \\
Stream \\
Spring Run \\
Rivulet \\
Brook \\
Stream Backwater \\
Irrigation Ditch \\
Slough \\
Bog \\
Ditch \\
Fen \\
Muskeg \\
Pond \\
Lagoon \\
Burrow Pit \\
Creek \\
Canal \\
Bayou \\
Marsh \\
Bay \\
Estuary \\
Lake \\
River \\
\hline
\end{tabular}

Table 17. Number of anisopterans and zygopterans found in each of NatureServe's global conservation ranks.

\begin{tabular}{cccc}
\hline Conservation Status & Anisoptera & Zygoptera & Total \\
\hline G1 & 6 & 0 & 6 \\
G2 & 11 & 4 & 15 \\
G3 & 27 & 7 & 34 \\
G4 & 73 & 31 & 104 \\
G5 & 189 & 87 & 276 \\
\hline
\end{tabular}


Table 18. Mean (standard deviation) geographic range, length of flight period, and habitat breadth for each conservation status within Anisoptera and Zygoptera. Geographic range indicates number of American states, Mexican states, and Canadian provinces. Length of flight period is the average number of months adults are flying, and habitat breadth is the number of habitats a species occupies.

\begin{tabular}{lcccc}
\hline & Conservation Status & Geographic Range & Length of Flight Season & Habitat Breadth \\
\hline Anisoptera & At-risk & $6.20(5.94)$ & $2.73(1.16)$ & $4.05(1.84)$ \\
& G4 & $13.37(7.42)$ & $3.49(1.23)$ & $3.73(1.74)$ \\
& G5 & $24.86(12.71)$ & $4.98(1.83)$ & $5.77(2.19)$ \\
Zygoptera & At-risk & $6.09(6.89)$ & & \\
& G4 & $9.52(8.04)$ & $5.40(3.44)$ & $4.81(2.79)$ \\
& G5 & $30.29(13.91)$ & $5.92(2.27)$ & $4.62(2.11)$ \\
& & & $5.98(2.13)$ & $5.79(2.27)$ \\
\hline
\end{tabular}


Table 19. Values from ordinal logistic regression for anisopterans and zygopterans. For anisopterans, the best-fitting model included the variables and interactions listed below, and all were significant. For zygopterans, the best-fitting model included only geographic range and length of flight period. * indicate p-values less than $0.05 ; * *$, less than $0.01 ; * * *$, less than 0.0001 .

\begin{tabular}{llccc}
\hline & Ecological Correlate & Parameter & Standard Error & t value \\
\hline Anisoptera & Geographic Range & 1.71 & 0.21 & $8.00^{* * *}$ \\
& Length of Flight Period & 1.15 & 0.28 & $4.18^{* *}$ \\
& Habitat Breadth & 0.65 & 0.22 & $2.96^{* *}$ \\
& Range x Flight Period & -0.74 & 0.26 & $-2.91^{* *}$ \\
& Habitat x Flight Period & 0.68 & 0.29 & $2.36^{*}$ \\
& & & & \\
Zygoptera & Geographic Range & 3.06 & 0.50 & $6.12^{* * *}$ \\
& Length of Flight Period & 0.50 & 0.23 & $2.15^{*}$ \\
\hline
\end{tabular}


Table 20 . Odds ratios and $95 \%$ confidence intervals of each significant variable for the ordinal logistic regression models with the lowest AIC values. In both Anisoptera and Zygoptera a 1-unit change in geographic range had the largest effect on conservation rank.

\begin{tabular}{llccc}
\hline & Ecological Correlate & Odds Ratio & 0.025 & 0.975 \\
\hline Anisoptera & Geographic Range & 5.53 & 3.68 & 8.54 \\
& Length of Flight Period & 3.17 & 1.93 & 5.72 \\
& Habitat Breadth & 1.91 & 1.27 & 3.00 \\
& Range x Flight Period & 0.48 & 0.29 & 0.78 \\
& Habitat x Flight Period & 1.97 & 1.16 & 3.60 \\
& & & & \\
\multirow{7}{*}{ Zygoptera } & Geographic Range & 21.32 & 8.78 & 63.21 \\
& Length of Flight Period & 1.65 & 1.06 & 2.63 \\
\hline
\end{tabular}




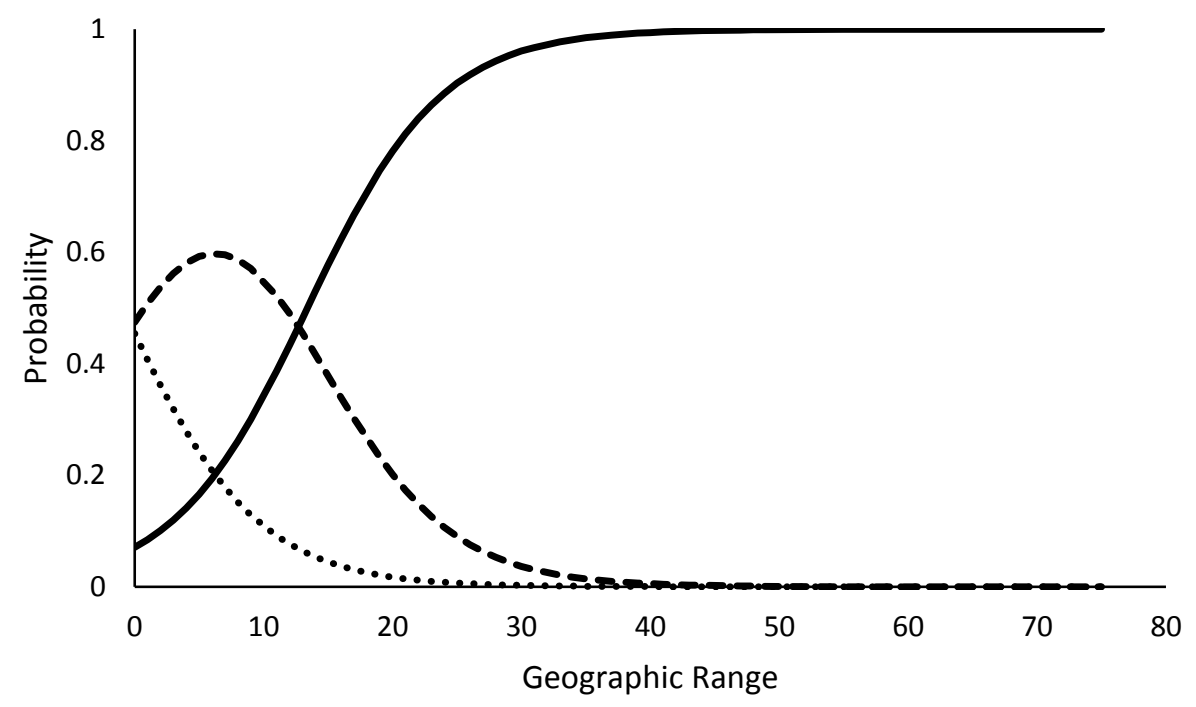

Figure 1. Prediction curves for predicting the probability of an odonate being a certain conservation status across geographic ranges. Increasing the geographic distribution of a species by one state increased the odds that the species was a G4 or G5 rank by 21.32 fold. Short-dashed line: "At-risk" conservation status; long-dashed line: G4 conservation status; solid line: G5 conservation status

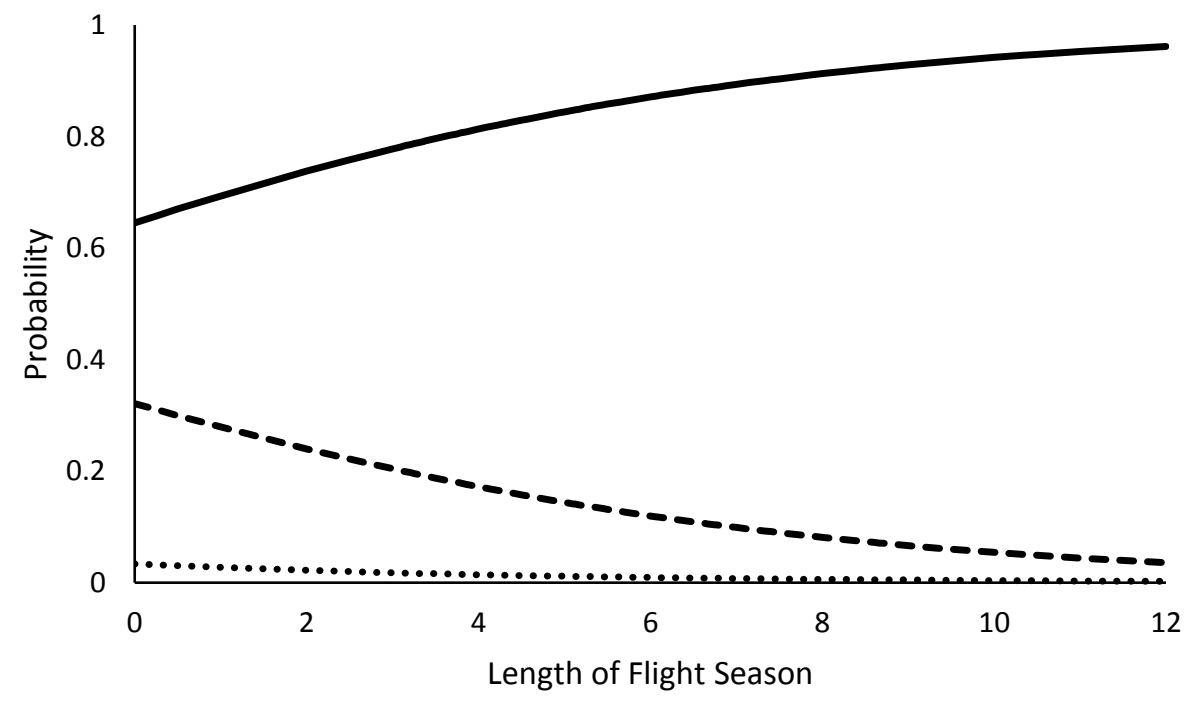


Figure 2. Prediction curves for determining a species' conservation status based on its flight period length. Increasing the length of a species' flight period by one month increased the odds that the species was a G4 or G5 by 1.64. Short-dashed line: "At-risk" conservation status; long-dashed line: G4 conservation status; solid line: G5 conservation status 


\section{CHAPTER V \\ CONCLUSION}

\section{Summary}

I took three distinct approaches to studying arthropod conservation in North America. My research on wolf spiders shows that not all arthropods are negatively affected by urban development. Some species are able to tolerate and disperse through an inhospitable matrix caused by urbanization. Other taxa, such as odonates, are negatively affected by urban development. However, even among odonates, their responses to urbanization are variable, and these differences are likely due to variations in ecological and life-history patterns. My dissertation suggests that invertebrates have much more variation in their responses to urban development than do vertebrates.

\section{Future Directions}

Future studies need to develop a comprehensive theoretical framework to predict the responses of arthropod taxa to urbanization. Foundational data are necessary in order to identify the biological and environmental mechanisms that drive the differential responses of arthropod taxa to urban development. Biological factors (e.g. dispersal ability and voltinism) will certainly contribute to which species are resilient to extinction. 
My research suggests that even passive forms of dispersal can help maintain gene flow so long as individuals successfully traverse large swaths of uninhabitable land and reach suitable habitat. Additionally, variations in dispersal abilities, as measured by geographic range size and length of flight period, correlate with extinction risk assessment in odonates. With such diverse modes of dispersal and variations in dispersal abilities, researchers need to investigate the ecological, behavioral, and morphological traits that enable some species to disperse successfully through inhospitable urban matrices while other species fail to do so. Direct measurements of long-distance dispersal are difficult to obtain (Nathan et al. 2003) and can be at least partially inferred from genetic analyses methods such as MIGRATE and BYESASS+, but more studies are needed to understand how different modes and patterns of dispersal contribute to species persistence in urban areas. Environmental mechanisms also need to be identified in order for invertebrates to be effectively conserved in urban areas (McDonnell and Hahs 2013). For example, I found that the amount of urban development surrounding a site affected pond communities but not stream communities. Future studies need to investigate why urban development affects odonate pond communities and not stream communities and if this pattern is found in other taxa as well.

In order to identify the mechanisms driving the urban biodiversity patterns that others and I have observed, I first need to better understand the basic ecology and distribution of invertebrates in general (D'Amen et al. 2013). In other words, in order for conservationists to effectively protect these taxa, I need to take a stronger interest in invertebrates and learn more about them. Sophisticated modeling techniques, which can inform conservation management practices, can only be effective if basic research has 
been conducted first (D'Amen et al. 2013) and researchers confidently know which environmental variables affect species persistence (Araujo and Guisan 2006).

\section{Conclusion}

The significance of urban areas in maintaining high levels of biodiversity is still being debated. Schwartz et al. (2014) concluded that the possibility of urban areas to contribute to animal conservation is low, but McDonnell and Hahs (2013) believe that cities can be important in conserving biodiversity. Certain species, such as $R$. rabida, may be able to tolerate urban areas, but study after study has shown that urban areas negatively affect biodiversity, especially those species that have narrow niches. If urban areas are to hold high levels of biodiversity, then society needs to take an active approach to making greener cities (Colding and Barthel 2013; McDonnell and Hahs 2013; Parker 2015) and conservationists need to put a stronger emphasis on learning more about the neglected 90\% (Redak 2000) of an estimated 8.7 million extant invertebrate species (Mora et al. 2011). 


\section{REFERENCES}

Abbott JC (2005) Dragonflies and damselflies of Texas and the South-Central United States: Texas; Louisiana, Arkansas, Oklahoma, and New Mexico. Princeton University Press, Princeton

Abel PD (2002) Water Pollution Biology, 2nd edn. Taylor and Francis, London

Alberti M (2005) The effects of urban patterns on ecosystem function. Int Reg Sci Rev 28:168-192

Alexandre CV, Esteves KE, de Moura e Mello MAM (2010) Analysis of fish communities along a rural-urban gradient in a neotropical stream (Piracicaba River Basin, São Paulo, Brazil). Hydrobiologia 64:97-114

Aliberti Lubertazzi MA, Ginsberg HS (2010) Emerging dragonfly diversity at small Rhode Island (U.S.A.) wetlands along an urbanization gradient. Urban Ecosyst 13:517-533

Alig RJ, Kline JD, Lichtenstein M (2004) Urbanization on the US landscape: looking ahead in the 21st century. Landsc Urban Plan 69:219-234

Allan JD (2004) Landscapes and riverscapes: the influence of land use on stream ecosystems. Annu Rev Ecol Evol Syst 35:257-284

Allen AP, O'Conner RJ (2000) Hierarchical correlates of bird assemblage structure on northeastern USA lakes. Environ Monit Assess 62:15-35

Allison PD (1999) Logistic Regression Using SAS®: Theory and Application. SAS Institute, Inc, Cary, NC

Altermatt F (2010) Climatic warming increases voltinism in European butterflies and moths. Proc R Soc B 277:1281-1287

Andreassen HP, Ims RA, Steinset OK (1996) Discontinuous habitat corridors: effects on male root vole movements. J Appl Ecol 33:555-560 
Anderson GS, Danielson BJ (1997) The effects of landscape composition and physiognomy on metapopulation size: the role of corridors. Landscape Ecol $12: 261-271$

Anderson SC, Farmer RG, Ferretti F, Houde ALS, Hutchings JA (2011) Correlates of vertebrate extinction risk in Canada. BioScience 61:538-549

Araujo MB, Guisan A (2006) Five (or so) challenges for species distribution modelling. J Biogeogr 33:1677-1688

Aronson MFJ, La Sorte FA, Nilon CH et al (2014) A global analysis of the impacts of urbanization on bird and plant diversity reveals key anthropogenic drivers. Proc $\mathrm{R}$ Soc B 281:20133330

Baker BS, Rodríguez-Robles JA, Cook JA (2015) Climate as a driver of tropical insular diversity: comparative phylogeography of two ecologically distinctive frogs in Puerto Rico. Ecography 38:769-781

Baird JM, May ML (1997) Foraging behavior of Pachydiplax longipennis (Odonata: Libelullidae). J Insect Behav 10:655-678

Ball-Damerow JE, M'Gonigle LK, Resh VH (2014) Changes in occurrence, richness, and biological traits of dragonflies and damselflies (Odonata) in California and Nevada over the past century. Biodiv Conserv 23:2107-2126

Barnosky AD, Matzke N, Tomiya S, Wogan GO, Swartz B, Quental TB, Marshall C, McGuire JL, Lindsey EL, Maguire KC, Mersey B (2011) Has the Earth's sixth mass extinction already arrived? Nature 471:51-57

Barua M, Gurdak DJ, Ahmed RA, Tamuly J (2012) Selecting flagships for invertebrate conservation. Biodivers Conserv 21:1457-1476

Bates D, Mächler M, Bolker B, Walker S (2014) Fitting linear mixed-effects models using lme4. J Stat Softw 67:1-48

Baum KA, Haynes KJ, Dillemuth FP, Cronin JT (2004) The matrix enhances the effectiveness of corridors and stepping stones. Ecology 85:2671-2676

Beerli P (2009) How to use MIGRATE or why are Markov chain Monte Carlo programs difficult to use? In: Bertorelle G, Bruford MW, Hauffe HC, Rizzoli A, Vernesi C (eds) Population Genetics for Animal Conservation, 1st edn. Cambridge University Press, Cambridge, UK 
Beerli P, Felsenstein J (1999) Maximum-likelihood estimation of migration rates and effective population numbers in two populations using a coalescent approach. Genetics 152:763-773

Beerli P, Felsenstein J (2001) Maximum likelihood estimation of a migration matrix and effective population sizes in $n$ subpopulations by using a coalescent approach. Proc Natl Acad Sci USA 98:4563-4568

Bell JR, Bohan DA, Shaw EM, Weyman GS (2005) Ballooning dispersal using silk: world fauna, phylogenies, genetics and models. Bull Entomol Res 95:69-144

Bennet PM, Owens IPF (1997) Variation in extinction risk among birds: chance or evolutionary predisposition? Proc R Soc B 264:401-408

Bierwagen BG (2007) Connectivity in urbanizing landscapes: the importance of habitat configuration, urban area size, and dispersal. Urban Ecosyst 10:29-42

Björklund M, Ruiz I, Senar JC (2010) Genetic differentiation in the urban habitat: the great tits (Parus major) of the parks of Barcelona city. Biol J Linnean Soc 99:919

Black SH, Shepard M, Allen MM (2001) Endangered invertebrates: the case for greater attention to invertebrate conservation. Endangered Species Update 18:42-50

Blair RB (1999) Birds and butterflies along an urban gradient: surrogate taxa for assessing biodiversity. Ecol Appl 9:164-170

Blair RB (2004) The effects of urban sprawl on birds at multiple levels of biological organization. Ecol Soc 9:2

Bond JE, Beamer DA, Lamb T, Hedin M (2006) Combining genetic and geospatial analyses to infer population extinction in mygalomorph spiders endemic to the Los Angeles region. Anim Conserv 9:145-157

Bonte D, Baert L, Lens L, Maelfait JP (2004) Effects of aerial dispersal, habitat specialization, and landscape structure on spider distribution across fragmented grey dunes. Ecography 27:343-349

Bonte D, Bossuyt B, Lens L (2007) Aerial dispersal plasticity under different wind velocities in a salt marsh wolf spider. Behav Ecol 18:438-443

Bonte D, Maelfait JP (2001) Life history, habitat use and dispersal of a dune wolf spider (Pardosa monticola (Clerck, 1757) Lycosidae, Araneae) in the Flemish coastal dunes (Belgium). Belg J Zool 131:145-157 
Bonte D, Vandenbroecke N, Lens L, Maelfait JP (2003) Low propensity for aerial dispersal in specialist spiders from fragmented landscapes. Proc Roy Soc B 270:1471-2954

Bonte D, Vanden Borre J, Lens L, Maelfait JP (2006) Geographical variation in wolf spider dispersal is related to landscape structure. Anim Behav 72:655-662

Booth DB, Jackson CR (1997) Urbanization of aquatic systems: degradation thresholds, stormwater detection, and the limits of mitigation. J Am Water Resour Assoc 33:1077-1090

Braaker S, Moretti M, Boesch R, Ghazoul J, Obrist MK, Bontadina F (2014) Assessing habitat connectivity for ground-dwelling animals in an urban environment. Ecol Appl 24:1583-1595

Brady AR, McKinley KS (1994) Nearctic species of the wolf spider genus Rabidosa (Araneae:Lycosidae). J Arachnol 22:138-160

Brönmark C, Hansson LA (2002) Environmental issues in lakes and ponds: current state and perspectives. Environ Conserv 29:290-306

Brook BW, Sodhi NS, Bradshaw CJA (2008) Synergies among extinction drivers under global change. Trends Ecol Evol 23:453-460

Cardillo M, Mace GM, Jones KE, Bielby J, Bininda-Edmonds ORP, Sechrest W, Orme CDL, Purvis A (2005) Multiple causes of high extinction risk in large mammals species. Science 309:1239-1241

Cardoso P, Erwin TL, Borges PAV, New TR (2011) The seven impediments in invertebrate conservation and how to overcome them. Biol Conserv 144: 26472655

Cardoso P, Borges PAV, Triantis KA, Ferrández MA, Martín JL (2011) Adapting the IUCN Red List criteria for invertebrates. Biol Conserv 144:2432-2440

Chace JE, Walsh JJ (2006) Urban effects on native avifauna: a review. Landsc Urban Plan 74:46-69

Christie FJ, Hochuli DF (2009) Responses of wasp communities to urbanization: effects on community resilience and species diversity. J Insect Conserv 13:213-221

Clark JA, May RM (2002) Taxonomic bias in conservation research. Science 297:191192

Clark TE, Samways MJ (1996) Dragonflies (Odonata) as indicators of biotope quality in the Kruger National Park, South Africa. J Appl Ecol 33:1001-1012 
Clausnitzer V, Kalkman VJ, Ram M, Collen B, Baillie JEM, Bedjanič M, Darwall WRT, Dijkstra KDB, Dow R, Hawking J, Karube H, Malikova E, Paulson D, Schütte K, Suhling F, Villanueva RJ, von Ellenrieder N, Wilson K (2009) Odonata enter the biodiversity crisis debate: The first global assessment of an insect group. Biol Cons 142:1864-1869

Colding J, Barthel S. (2013) The potential of 'Urban Green Commons' in the resilience building of cities. Ecol Econom 86:156-166

Collier KJ, Clements BL (2011) Influences of catchment and corridor imperviousness on urban stream macroinvertebrate communities at multiple spatial scales. Hydrobiologia 664:35-50

Concepción ED, Moretti M, Altermatt F, Nobis MP, Obrist MK (2015) Impacts of urbanization on biodiversity: the role of species mobility, degree of specialization and spatial scale. Oikos 124:1571-1582

Constible JM, Gregory PT, Larsen KW (2010) The pitfalls of extrapolation in conservation: movements and habitat use of a threatened toad are different in the boreal forest. Anim Conserv 13:43-52

Corbet PS (1999) Dragonflies: Behavior and Ecology of Odonata. Cornell University Press, Ithaca

Corbet PS, Suhling F, Soendgerath D (2006) Voltinism of Odonata: a review. Int J Odonatol 9:1-44

Corser JD, White EL, Schlesinger MD (2015) Adult activity and temperature preference drives region-wide damselfly (Zygoptera) distributions under a warming climate. Biol Lett 11: 20150001

Craves JA, O’Brien DS (2013) The Odonata of Wayne County, MI: Inspiration for renewed monitoring of urban areas. Northeast Nat 20:341-362

Cuffney TF, Brightbill RA, May JT, Waite IR (2010) Responses of benthic macroinvertebrates to environmental changes associated with urbanization in nine metropolitan areas. Ecol Appl 20:1384-1401

Czech B, Krausman PR, Devers PK (2000) Economic associations among causes of species endangerment in the United States. BioScience 50:593-601

D’Amen M, Bombi P, Campanaro A, Zapponi L, Bologna MA, Mason F (2013) Possible directions in the protection of the neglected invertebrate biodiversity. Anim Conserv 16:383-385 
Davies KF, Margules CR, Lawrence JF (2004) A synergistic effect puts rare, specialized species at greater risk of extinction. Ecology 85:265-271

De Jesús-Crespo R, Ramírez A (2011) Effects of urbanization on stream physiochemistry and macroinvertebrate assemblages in a tropical urban watershed in Puerto Rico. J N Am Benthol Soc 30:739-750

Díaz AM, Alonso MLS, Gutiérrez MRVA (2008) Biological traits of stream macroinvertebrates from a semi-arid catchment: patterns along complex environmental gradients. Freshwater Biol 53:1-21

Delaney KS, Riley SPD, Fisher RN (2010) A Rapid, Strong, and Convergent Genetic Response to Urban Habitat Fragmentation in Four Divergent and Widespread Vertebrates. PLoS ONE 5:e12767

Desender K, Small E, Gaublomme E, Verdyck P (2005) Rural-urban gradients and the population genetic structure of woodland ground beetles. Conserv Genet 6: 51-62

Devictor V, Julliard R, Couvet D, Lee A, Jiguet F (2007) Functional homogenization effect of urbanization on bird communities. Conserv Biol 21:741-751

Diehl E, Mader VL, Wolters V, Birkhofer K (2013) Management intensity and vegetation complexity affect web-building spiders and their prey. Oecologia 173:579-589

De Caceres, M., Legendre, P. (2009) Associations between species and groups of sites: in dices and statistical inference. Ecology 90:3566-3574

Dudgeon D, Arthington AH, Gessner MO, Kawabata Z, Knowler DJ, Lévêque C, Naiman RJ, Prieur-Richard AH, Soto D, Stiassny MLJ, Sullivan CA (2006) Freshwater biodiversity: importance, threats, status and conservation challenges. Biol Rev 81:163-182

Dutra S, De Marco P (2015) Bionomic differences in odonates and their influence on the efficiency of indicator species of environmental quality. Ecol Indic 49:132-142

Entling MH, Stämpfli K, Ovaskainen O (2011) Increased propensity for aerial dispersal in disturbed habtiats due to intraspecific variation and species turnover. Oikos 120:1099-1109

Epps CW, Palsbøll PJ, Wehausen JD, Roderick GK, Ramey RR, McCullough DR (2005) Highways block gene flow and cause a rapid decline in genetic diversity of desert bighorn sheep. Ecol Lett 8:1029-1038

ESRI (2015) ArcGIS Desktop Student Edition: Release 10.2. Environmental Systems Research Institute, Redlands 
Excoffier L, Smouse PE, Quattro JM (1992) Analysis of molecular variance inferred from metric distances among DNA haplotypes: application to human mitochondrial DNA restriction data. Genetics 131:479-491

Faber-Langendoen D, Nichols J, Master L, Snow K, Tomaino A, Bittman R, Hammerson G, Heidel B, Ramsay L, Teucher A, Young B (2012) NatureServe Conservation Status Assessments: Methodology for Assigning Ranks. NatureServe, Arlington, VA

Faeth SH, C Bang, S Saari (2011) Urban biodiversity: patterns and mechanisms. Ann NY Acad Sci 1223:69-81

Faeth SH, Warren PS, Shochat E, Marussich WA (2005) Trophic dynamics in urban communities. BioScience 55:399-407

Fahrig L (1997) Relative effects of habitat loss and fragmentation on population extinction. J Wildl Manag 61:603-610

Fahrig L (2003) effects of habitat fragmentation on biodiversity. Annu Rev Ecol Evol Syst 34:487-515

Fast AW, Moss B, Wetzel RG (1973) Effects of artificial aeration on the chemistry and algae of two Michigan lakes. Water Resour Res 9:624-647

Fattorini S (2014) Island biogeography of urban insects: tenebrionid beetles from Rome tell a different story. J Insect Conserv 18:729-735

Fetzner JW (1999) Extracting high-quality DNA from shed reptile skins: a simplified method. BioTechniques 26:1052-1054

Fisher DO, Owens IPF (2004) The comparative method in conservation biology. Trends Ecol Evol 19:391-398

Fleishman E, Noos RF, Noon BR (2006) Utility and limitations of species richness metrics for conservation planning. Ecol Indic 6:543-553

Foufopoulos J, Ives AR (1999) Reptile extinctions on land-bridge islands: Life-history attributes and vulnerability to extinction. Amer Nat 153:1-25

Fuller MR, Doyle MW, Strayer DL (2015) Causes and consequences of habitat fragmentation in river networks. Ann NY Acad Sci 1355:31-51

Foelix R (2011) Biology of Spiders, 3rd edn. Oxford University Press, New York, New York 
Fonesca DM, Hart DD (1996) Density-dependent dispersal of black fly neonates is mediated by flow. Oikos 75:49-58

Fox J, Weisberg S (2011) An R companion to applied regression. 2nd edn. Sage, Thousand Oaks

Framenau VW (2005) Gender specific differences in activity and home range reflect morphological dimorphism in wolf spiders (Araneae, Lycosidae). J Arachnol 33:334-346

Furrer RD, Pasinelli G (2016) Empirical evidence for source-sink populations: a review on occurrence, assessments and implications. Biol Rev 91:782-795

García VB, Lucifora LO, Myers RA (2008) The importance of habitat and life history to extinction risk in sharks, skates, rays and chimaeras. Proc R Soc B 275:83-89

Gaston KJ (1994) Geographic range sizes and trajectories to extinction. Biodiv Let 2:163-170

Gaston KJ, Fuller RA (2008) Commonness, population depletion and conservation biology. Trends Ecol Evol 23:14-19

Gillespie RG, Baldwin BG, Waters JM, Fraser CI, Nikula R, Roderick GK (2012) Longdistance dispersal: a framework for hypothesis testing. Trends Ecol Evol 27:47-56

Goertzen D, Suhling F (2013) Promoting dragonfly diversity in cities: major determinants and implications for urban pond design. J Insect Conserv 17:399-409

Goertzen D, Suhling F (2015) Central European cities maintain substantial dragonfly species richness- a change for biodiversity conservation? Insect Conserv Divers $8: 238-246$

González-Suárez M, Revilla E (2013) Variability in life-history and ecological traits is a buffer against extinction in mammals. Ecol Let 16:242-251

Gortat T, Rutkowski R, Gryczyńska, Pieniążek, Kozakiewicz A, Kozakiewicz M (2014) Anthropopresssure gradients and the population genetic structure of Apodemus agrarius. Conserv Genet 16:649-659

Grewe Y, Hof C, Dehling DM, Brandl R, Brändle M (2012) Recent range shifts in European dragonflies provide support for an inverse relationship between habitat predictability and dispersal. Global Ecol Biogeogr 22:403-409

Grimm NB, Faeth SH, Golubiewski NE, Redman CL, Wu J, Bai X, Briggs JM (2008) Global change and the ecology of cities. Science 319:756-760 
Grodsky SM, Iglay RB, Sorenson CE, Moorman CE (2015) Should invertebrates receive greater inclusion in wildlife research journals? J Wildl Manag 79:529-536

Guillot G, Mortier F, Estoup A (2005) Geneland: A program for landscape genetics. Mol Ecol Notes 5:712-715

Gurevitch J, Padilla DK (2004) Are invasive species a major cause of extinctions? Trends Ecol Evol 19:470-474

Haddad NM, Brudvig LA, Colbert J, Davies KF, Gonzalez A, Holt RD, Lovejoy TE, Sexton JO, Austin MP, Collins CD, Cook WM, Damschen EI, Ewers RM, Foster BL, Jenkins CN, King AJ, Laurance WF, Levey DJ, Margules CR, Melbourne BA, Nicholls AO, Orrock JL, Song DX, Townshend JR (2015) Habitat fragmentation and its lasting impact on Earth's ecosystems. Sci Adv 1:e1500052

Hanna E, Cardillo M (2013) A comparison of current and reconstructed historic geographic range sizes as predictors of extinction risk in Australian mammals. Biol Conserv 158:196-204

Hansen AJ, Knight RL, Marzluff JM, Powell S, Brown KK, Guide PH, Jones K (2005) Effects of exurban development on biodiversity: patterns, mechanisms, and research needs. Ecol Appl 15:1893-1905

Hassall C (2014) The ecology and biodiversity of urban ponds. WIREs Water 1:187-206

Hassall C, Thompson DJ, French GC, Harvey IF (2007) Historical changes in the phenology of British Odonata are related to Climate. Glob Chang Biol 13:933-941

Havel JE, Kovalenko KE, Thomaz SM, Amalfitano S, Kats LB (2015) Aquatic invasive species: challenges for the future. Hydrobiologia 750:147-170

Hedrick PJ (2011) Genetics of populations. Jones and Bartlett, Sudbury

Heinrichs JA, Bender DJ, Schumaker NH (2016) Habitat degradation and loss as key drivers of regional population extinction. Ecol Model 335:64-73

Heiser M, Schmitt T (2010) Do different dispersal capabilities influence the biogeography of the western Palearctic dragonflies (Odonata)? Biol J Linnean Soc 99:177-195

Henein K, Merriam G (1990) The elements of connectivity where corridor quality is variable. Landscape Ecol 4:157-170

Henle K, Sarre S, Wiegand K (2004) The role of density regulation in extinction processes and population viability analysis. Biodiv Conserv 13:9-52 
Hill MJ, Wood PJ (2014) The macroinvertebrate biodiversity and conservation value of garden and field ponds along a rural-urban gradient. Fundam Appl Limnol 185:107-119

Hitchings SP, Beebee TJC (1997) Genetic substructuring as a result of barriers to gene flow in urban Rana temporaria (common frog) populations: implications for biodiversity conservation. Heredity 79:117-127

Holm S (1979) A simple sequentially rejective multiple test procedure. Scand J Stat 6:6570

Homer CG, Dewitz JA, Yang L, Jin S, Danielson P, Xian G, Coulston J, Herold ND, Wickham JD, and Megown K (2015) Completion of the 2011 National Land Cover Database for the conterminous United States-Representing a decade of land cover change information. Photogramm Eng Remote Sens 81:345-354

Hornung E, Tóthmérész B, Magura T, Vilisics F (2007) Changes of isopod assemblages along an urban-suburban-rural gradient in Hungary. Eur J Soil Biol 43:158-165

Horsák M, Lososová Z, Čejka T, Juřičková L, Chytrý M (2013) Diversity and biotic homogenization of urban land-snail faunas in relation to habitat types and macroclimate in 32 central European cities. PLOS One 8: e71783

Hutchings JA, Myers RA, García VB, Lucifora LO, Kuparinen A (2012) Life-history correlates of extinction risk and recovery potential. Ecol Appl 22:1061-1067

Ishitani M, Kotze DJ, Niemelä J (2003) Changes in carabid beetle assemblage across an urban-rural gradient in Japan. Ecography 26:481-489

Jeanmougin M, Leprieur F, Loïs G, Clergeau P (2014) Fine-scale urbanization affects Odonata species diversity in ponds of a megacity (Paris, France). Acta Oecol 59:26-34

Jeppsson T, Forslund P (2014) Species' traits explain differences in Red list status and long-term population trends in longhorn beetles. Anim Conserv 17:332-341

Jha S, Kremen C (2013) Urban land use limits regional bumble bee gene flow. Mol Ecol 22:2483-2495

Jones EL, Leather SR (2012) Invertebrates in urban areas: a review. Eur J Entomol 109: 463-478

Jones KE, Purvis A, Gittleman JL (2003) Biological correlates of extinction risk in bats. Amer Nat 161:601-614 
Kark S, Iwaniuk A, Schalimtzek A, Banker E (2007) Living in the city: can anyone become an 'urban exploiter'? J Biogeogr 34:638-651

Kitahara M, Fujii K (1994) Biodiversity and community structure of temperate butterfly species within a gradient of human disturbance: an analysis based on the concept of generalist vs. specialist strategies. Res Popul Ecol 36:187-199

Kearse M, Moir R, Wilson A, Stones-Havas S, Cheung M, Sturrock S, Buxton S, Cooper A, Markowitz S, Duran C, Thierer T, Ashton B, Meintjes P, Drummond A (2012) Geneious Basic: an integrated and extendable desktop software platform for the organization and analysis of sequence data. Bioinformatics 28:1647-1649

Keller I, Largiadèr CR (2003) Recent habitat fragmentation caused by major roads leads to reduction of gene flow and loss of genetic variability in ground beetles. Proc $\mathrm{R}$ Soc Lond B 279:417-423

Kennen JG, Riva-Murray K, Beaulieu KM (2010) Determining hydrologic factors that influence stream macroinvertebrate assemblages in northeastern US. Ecohydol 3:88-106

Kim KC (1993) Biodiversity, conservation and inventory: why insects matter. Biodiv Conserv 2:191-214

Kinzig AP, Warren P, Martin C, Hope D, Katti M (2005) The effects of human socioeconomic status and cultural characteristics on urban patterns of biodiversity. Ecol Soc 10:23

Knell RJ, Thackeray SJ (2016) Voltinism and resilience to climate-induced phenological mismatch. Clim Chang 137:525-539

Knop E (2016) Biotic homogenization of three insect groups due to urbanization. Global Change Biol 22:228-236

Komonen A, Grapputo A, Kaitala V, Kotiaho JS, Päivinen J (2004) The role of niche breadth, resource availability and range position on the life history of butterflies. Oikos 105:41-54

Korkeamäki E, Suhonen J (2002) Distribution and habitat specialization of species affect local extinction in dragonfly Odonata populations. Ecography 25:459-465

Kotze J, Venn S, Niemelä J, Spence J (2011) Effects of urbanization on the ecology and evolution of arthropods. In Niemelä J (ed) Urban ecology, patterns, processes and applications. Oxford University Press, New York, pp 159-166

Kotiaho JS, Kaitala V, Komonen A, Päivinen J (2005) Predicting the risk of extinction from shared ecological characteristics. Proc Natl Acad Sci USA 102:1963-1967 
Kreiter NA, Wise DH (2001) Prey availability limits fecundity and influences the movement pattern of female fishing spiders. Oecologia 127:417-424

Kronfrost MR, Fleming TH (2001) Lack of genetic differentiation among widely spaced subpopulations of a butterfly with home range behavior. Heredity 86:243-250

Kruger DJD, Hamer AJ, Du Preez LH (2015) Urbanization affects frog communities at multiple scales in a rapidly developing African city. Urban Ecosyst 18:1333-1352

Kudavidanage EP, Wanger TC, De Alwis C, Sanjeewa S, Kotagama SW (2011) Amphibian and butterfly diversity across a tropical land-use gradient in Sri Lanka; implications for conservation decision making. Anim Conserv 15:253-265

Küry D, Christ J (2010) Odonata fauna and conservation in the canton Basel-Stadt (NW Switzerland). Mitt Naturforsch Gesellsch Basel 12:105-118

Kutcher TE, Bried JT (2014) Adult Odonata conservatism as an indicator of freshwater wetland condition. Ecol Indic 38:31-39

Landguth EN, Fedy BC, Oyler-McCance SJ, Garey AL, Emel SH, Mumma M, Wagner HH, Fortin MJ, Cushman SA (2012) Effects of sample size, number of markers, and allelic richness on the detection of spatial genetic pattern. Mol Ecol Resour 276-284

Lane A, Shine R (2011) Intraspecific variation in the direction and degree of sex-based dispersal among sea-snake populations. Mol Ecol 20:1870-1876

Leakey R, Lewin R (1995) The sixth extinction: patterns of life and the future of humankind. Doubleday, New York

Leather SR (2009) Institutional vertebratism threatens UK food security. Trends Ecol Evol 24:413-414

Leather SR, Basset Y, Hawkins BA (2008) Insect conservation: finding the way forward. Insect Conserv Divers 1:67-69

Lee JS, Ruell EW, Boydston EE, Lyren LM, Alonso RS, Troyer JL, Crooks KR, VandeWoude S (2012) Gene flow and pathogen transmission among bobcats (Lynx rufus) in a fragmented urban landscape. Mol Ecol 21:1617-1631

Lee Foote A, Rice Hornung CL (2005) Odonates as biological indicators of grazing effects on Canadian prairie wetlands. Ecol Entomol 30:273-283 
Li YC, Korol AB, Fahima T, Beiles A, Nevo E (2002) Microsatellites: genomic distribution, putative functions and mutational mechanisms: a review. Mol Ecol 11:2453-2465

Losey JE, Vaughan M (2006) The economic value of ecological services provided by insects. Bioscience 56:311-323

Lowe EC, Wilder SM, Hochuli DF (2014) Urbanisation at multiple scales is associated with larger size and higher fecundity of an orb-weaving spider. PLoS One 9:e105480

Luck GW, Smallbone LT (2010) Species diversity and urbanization: patterns, drivers and implications. In Gaston KJ (ed) Urban Ecology. Cambridge University Press, Cambridge. Pp 88-119

Magle SB, Hunt VM, Vernon M, Crooks KR (2012) Urban wildlife research: past, present, and future. Biol Conserv 155:25-32

Magura T, Horváth R, Tóthmérész B (2010) Effects of urbanization on ground-dwelling spiders in forest patches, in Hungary. Landscape Ecol 25:621-629

Magura T, Tóthmérész B, Molnár T (2004) Changes in carabid beetle assemblages along an urbanisation gradient in the city of Debrecen, Hungary. Landscape Ecol $19: 747-759$

Manier MK, Arnold SJ (2005) Population genetic analysis identifies source-sink dynamics for two sympatric garter snake species (Thamnophis elegans and Thmnophis sirtalis). Mol Ecol 14:3965-3976

Manolis TD (2003) Dragonflies and Damselflies of California. University of California Press, Berkeley and Los Angeles

Marshall S, Pettigrove V, Carew M, Hoffmann A (2010) Isolation in the impact of sediment toxicity in urban streams. Environ Pollut 158:1716-1725

Marzluff JM (2001) Worldwide urbanization and its effects on birds. In: Marzluff JM, Bowman R, Donnelly R (eds) Avian ecology and conservation in an urbanizing world. Springer US, New York. Pp 19-47

Matthysen E (2012) Multicausality of dispersal: a review. In Colbert J, Baguette M, Benton TG, Bullock JM (eds) Dispersal Ecology and Evolution. Oxford University Press, Oxford, pp 3-18

Mattila N, Kaitala V, Komonen A, Kotiaho JS, Paivinen J (2006) Ecological determinants of distribution decline and risk of extinction in moths. Conserv Biol 20:1161-1168 
McCauley SJ, Davis CJ, Wener EE, Robeson MS (2014) Dispersal, niche breadth and population extinction: colonization ratios predict range size in North American dragonflies. J Anim Ecol 83:858-865

McDonald RI, Kareiva P, Forman RTT (2008) The implications of current and future urbanization for global protected areas and biodiversity conservation. Biol Conserv 141:1695-1703

McDonnell MJ, Hahs AK (2008) The use of gradient analysis studies in advancing our understanding of the ecology of urbanizing landscapes: current status and future directions. Landscape Ecol 23:1143-1155

McIntyre NE (2000) Ecology of urban arthropods: a review and a call to action. Ann Entomol Soc Am 93:825-835

McIntyre NE, Rango J, Fagan WF, Faeth SH (2001) Ground arthropod community structure in a heterogeneous urban environment. Landsc Urban Plan 52:257-274

McKinney M (1997) Extinction vulnerability and selectivity: combining ecological and paleontological views. Annu Rev Ecol Syst 28:495-516

McKinney M (1999) High rates of extinction and threat in poorly studied taxa. Conserv Biol. 13:1273-1281

McKinney M (2002) Urbanization, biodiversity, and Conservation. BioScience 52:883890

McKinney M (2006) Urbanization as a major cause of biotic homogenization. Biol Conserv 127:247-260

McKinney M (2008) Effects of urbanization on species richness: A review of plants and animals. Urban Ecosyst 11:161-176

McKinney ML, Lockwood JL (1999) Biotic homogenization: a few winners replacing many losers in the next mass extinction. Trends Ecol Evol 14:450-453

McRae BH (2006) Isolation by resistance. Evolution 60: 1551-1561

McRae BH, Kavanagh DM (2011) Linkage Mapper Connectivity Analysis Software. The Nature Conservancy, Seattle WA. Available at: http://www.circuitscape.org/linkagemapper

McRae BH (2012a) Barrier Mapper Connectivity Analysis Software. The Nature Conservancy, Seattle WA. Available at: http://www.circuitscape.org/linkagemapper 
McRae BH (2012b) Centrality Mapper Connectivity Analysis Software. The Nature Conservancy, Seattle WA. Available at:

http://www.circuitscape.org/linkagemapper

McRae BH (2012c) Pinchpoint Mapper Connectivity Analysis Software. The Nature Conservancy, Seattle WA. Available at:

http://www.circuitscape.org/linkagemapper

McRae BH, Shirk AJ, Platt JT (2013a). Gnarly Landscape Utilities: Resistance and Habitat Calculator User Guide. The Nature Conservancy, Seattle WA. Available at: http://www.circuitscape.org/gnarly-landscape-utilities

McRae BH, Shah VB, Mohapatra TK (2013b) Circuitscape 4 User Guide. The Nature Conservancy, Seattle WA. Available at: http://www.circuitscape.org

Meirmans PG (2014) Nonconvergence in Bayesian estimation of migration rates. Mol Ecol Resour 14: 726-733

Meirmans PG, Hedrick PW (2011) Assessing population structure: Fst and related measures. Mol Ecol Resour 11:5-18

Mikulíček P, Pišút P (2012) Genetic structure of the marsh frog (Pelophylas ridibundus) populations in urban landscape. Eur J Wildl Res 58:833-845

Monteiro-Júnior CS, Couceiro SRM, Hamada N, Juen L (2013) Effect of vegetation removal for road building on richness and composition on Odonata communities in Amazonia, Brazil. Int J Odontal 16:135-144

Monteiro-Júnior CS, Juen L, Hamada N (2014) Effects of urbanization on stream habitats and associated adult dragonfly and damselfly communities in central Brazilian Amazonia. Landscape Urban Plan 127:28-40

Monteiro-Júnior CS, Juen L, Hamada N (2015) Analysis of urban impacts on aquatic habitats in the central Amazon basin: adult odonates as bioindicators of environmental quality. Ecol Indic 48:303-311

Moore AA, Palmer MA (2005) Invertebrate biodiversity in agricultural and urban headwater streams: implications for conservation and management. Ecol Appl $15: 1169-1177$

Morrison C, Hero JM (2003) Geographic variation in life-history characteristics of amphibians: a review. J Anim Ecol 72:270-279 
Morse CC, Huryn AD, Cronan C (2003) Impervious surface area as a predictor of the effects of urbanization on stream insect communities in Maine, USA. Environ Monit Assess 89:95-127

Munshi-South J (2012) Urban landscape genetics: canopy cover predicts gene flow between white-footed mouse (Peromyscus leucopus) populations in New York City. Mol Ecol 21:1360-1378

Murray BR, Hose GC (2005) Life-history and ecological correlates of decline and extinction in the endemic Australian frog fauna. Austral Ecol 30:564-571

Nath HB, Griffiths RC (1993) The coalescent in two colonies with symmetric migration. J Math Biol 31:841-851

NatureServe Explorer (2009) NatureServe Explorer: an only encyclopedia of life [web application]. Version 7.1 NatureServe, Arlington, VA. Available from: http://www.natureserve.org/explorer

Neal JW, Chittams JL, Bentz J (1997) Spring emergence by larvae of the Eastern Tent Caterpillar (Lepidoptera: Lasiocampidae): a hedge against high-risk conditions. Ann Entomol Soc Am 90:596-603

Needham JG, Westfall MJ, May ML (2000) Dragonflies of North America. Scientific Publishers, Gainesville

Nelson KC, Palmer MA (2007) Stream temperature surges under urbanization and climate change: data, models, and responses. J Am Water Resour Assoc 43:440452

Noël S, Lapointe FJ (2010) Urban conservation genetics: Study of a terrestrial salamander in the city. Biol Conserv 143:2823-2831

Nylin S, Bergström A (2009) Threat status in butterflies and its ecological correlates: how far can we generalize? Biodivers Conserv 18:3243-3267

Öckinger E, Smith HG (2008) Do corridors promote dispersal in grassland butterflies and other insects? Landscape Ecol 23:27-40

Ogai T, Kenta T (2016) The effects of vegetation types and microhabitats on carabid beetle community composition in cool temperate Japan. Ecol Res 31:177-188

O'Grady JJ, Reed DH, Brook BW, Frankham R (2004) What are the best correlates of predicted extinction risk? Biol Conserv 118:513-520 
Oksanen J, Blanchet FG, Kindt R, Legendre P, O'Hara RB, Simpson GL, Solymos P, Henry M, Stevens H, Wagner H (2013) Vegan: community ecology package. R package version $2.0-10$

Olden JD, Rooney TP (2006) On defining and quantifying biotic homogenization. Global Ecol Biogeogr 15:113-120

Pardee GL, Philpott SM (2014) Native plants are the bee's knees: local and landscape predictors of bee richness and abundance in backyard gardens. Urban Ecosyst 17:641-659

Paul MJ, Meyer JL (2001) Stream in the urban landscape. Annu Rev Ecol Syst 32:333365

Paulson DR (2009) Dragonflies of the West. Princeton University Press, Princeton

Paulson DR (2011) Dragonflies of the East. Princeton University Press, Princeton

Paulson DR, Dunkle SW (2009) A checklist of North America Odonata

Paulson DR, Jenner CE (1971) Population structure in overwintering larval Odonata in North Carolina in relation to adult flight season. Ecology 52:96-107

Pavao-Zuckerman MA, Coleman DC (2007) Urbanization alters the functional composition, but not taxonomic diversity, of the soil nematode community. Appl Soil Ecol 35:329-339

Peakall R, Smouse P (2012) GenAlEx 6.5: genetic analysis in Excel. Population genetic software for teaching and research—an update. Bioinformatics 28:2537-2539

Pena EA, Slate E (2006) Global validation of linear models. J Am Stat Assoc 101: 341345

Pickett STA, Cadensasso ML, Grove JM, Nilon CH, Pouyat RV, Zipperer WC, Costanza R (2008) Urban ecological systems: linking terrestrial ecological, physical, and socioeconomic components of metropolitan areas. Annu Rev Ecol Syst 32:127157

Pillsbury FC, Miller JR (2008) Habitat and landscape characteristics underlying anuran community structure along an urban-rural gradient. Ecol Appl 18:1107-1118

Powney GD, Cham SSA, Smallshire D, Isaac NJB (2015) Trait correlates of distribution trends in the Odonata of Britain and Ireland. PeerJ 3:e1410

Prevedello JA, Vieira MV (2010) Does the type of matrix matter? A quantitative review of the evidence. Biodivers Conserv 19:1205-1223 
Pritchard G, Leggott M (1987) Temperature, incubation rates, and origins of dragonflies. In: Advances in odonatology. Pp 121-126

Prugh LR, Hodges KE, Sinclair ARE, Brashares JS (2008) Effect of habitat area and isolation on fragmented animal populations. Proc Natl Acad Sci USA 105:2077020775

Pulliam RH, Danielson BJ (1991) Sources, sinks, and habitat selection: A landscape perspective on population dynamics. Amer Nat 137:S50-S66

Purvis A, Gittleman JL, Cowlishaw G, Mace GM (2000) Predicting extinction risk in declining species. Proc R Soc Lond B 267:1947-1952

R Core Development Team (2015). R: A language and environment for statistical computing. R Foundation for Statistical Computing, Vienna, Austria.

Raciti SM, Hutyra LR, Rao P, Finzi AC (2012) Inconsistent definitions of "urban" result in different conclusions about the size of urban carbon and nitrogen stocks. Ecol Appl 22:1015-1035

Rabinowitz D (1981) Seven forms of rarity. In: Synge H (ed) The biological aspects of rare plant conservation, Wiley-Interscience, New York, pp 205-217

Ramirez MG, Haakonsen KE (1999) Gene flow among habitat patches on a fragmented landscape in the spider Argiope trifasciatat (Araneae: Araneidae). Heredity $83: 580-585$

Redak RA (2000) Arthropods and multispecies habitat conservation plans: are we missing something? Environ Manage 26:S97-S107

Remsburg AJ, Turner MG (2009) Aquatic and terrestrial drivers of dragonfly (Odonata) assemblages within and among north-temperate lakes. J N Am Benthol Soc 28:44-56

Reed DH, Frankham R (2003) Correlation between fitness and genetic diversity. Conserv Biol 17: 230-237

Reed DH, Nicholas AC, Stratton GE (2007a) Genetic quality of individuals impacts population dynamics. Anim Consev 10:275-283

Reed DH, Nicholas AC, Stratton GE (2007b) Inbreeding levels and prey abundance interact to determine fecundity in natural populations of two species of wolf spider. Conserv Genet 8:1061-1071 
Reed DH, Teoh VH, Stratton GE, Hataway RA (2011) Levels of gene flow among populations of a wolf spider in a recently fragmented habitat: current versus historical rates. Conserv Genet 12:331-335

Reynolds JD (2003) Life histories and extinction risk. In: Blackburn TM, Gaston KJ (eds) Macroecology: concepts and consequences, Blackwell, Oxford, pp 195-217

Reynolds JD, Webb TJ, Hawkins LA (2005) Life history and ecological correlates of extinction risk in European freshwater fishes. Can J Fish Aquat Sci 62:854-862

Ricketts TH (2001) The matrix matters: effective isolation in fragmented landscapes. Am Nat 158:87-99

Rousset F (1997) Genetic differentiation and estimation of gene flow from F-statistics under isolation by distance. Genetics 145:1219-1228

Rousset F (2008) GENEPOP'007: a complete re-implementation of the GENEPOP software for Windows and Linux. Mol Ecol Resour 8:103-106

Roy AH, Rosemond AD, Paul MJ, Leigh DS, Wallace JB (2003) Stream macroinvertebrate response to catchment urbanization (Georgia, USA). Freshw Biol 48:329-346

Rundle SD, Bilton DT, Abbott JC, Foggo A (2007) Range size in North American Enallagma damselflies correlates with wing size. Freshwater Biol 52:471-477

Rykken JJ, Jepson PC, Moldenke AR (2011) Ground-dwelling arthropod distribution and movement across a fragmented riparian forest. Northwest Sci 85:527-541

Sahlén G (2006) Specialists vs. generalists in the Odonata-the importance of forest environments in the formation of diverse species pools. In: Rivera AC (ed) Forests and Dragonflies. Pensoft, Mosow, pp153-179

Samways MJ (2005) Insect diversity conservation. Cambridge University Press, Cambridge

Samways MJ, Steytler NS (1996) Dragonfly (Odonata) distribution patterns in urban and forest landscapes, and recommendations for riparian management. Biol Conserv 78:279-288

Santonastaso TT, Dubach J, Hauver SA, Graser WH, Gehrt SD (2012) Microsatellite analysis of raccoon (Procyon lotor) population structure across an extensive metropolitan landscape. J Mammal 93:447-455 
Sato M, Kohmatsu Y, Yuma M, Tsubaki Y (2008) Population genetic differentiation in three sympatric damselfly species in a highly fragmented urban landscape (Zygoptera: Coenagrionidae). Odonatologica 37:131-144

Scott MC (2006) Winners and losers among stream fishes in relation to land use legacies and urban development in the southeastern US. Biol Conserv 127:301-309

Schäfer MA, Hille A, Uhl GB (2001) Geographical patterns of genetic subdivision in the cellar spider Pholcus phalangioides (Araneae). Heredity 86:94-102

Schaub M, Aebischer A, Gimenez O, Berger S, Arlettaz R (2010) Massive immigration balances high anthropogenic mortality in a stable eagle owl population: lessons for conservation. Biol Conserv 143:1911-1918

Schuelke M (2000) An economic method for the fluorescent labeling of PCR fragments. Nat Biotechnol 18:233-234

Seto KC, Güneralp B, Hutyra LR (2012) Global forecasts of urban expansion to 2030 and direct impacts on biodiversity and carbon pools. Proc Natl Acad Sci USA 109: $16083-16088$

Shochat E, Warren PS, Faeth SH, McIntyre NE, Hope D (2006) From patterns to emerging processes in mechanistic urban ecology. Trends Ecol Evol 21:186-191

Slatkin M, Maddison WP (1989) A cladistics measure of gene flow inferred from the phylogenies of alleles. Genetics 123:603-613

Somers KA, Bernhardt ES, Grace JB, Hassett BA, Sudduth EB, Wang S, Urban DL (2013) Streams in the urban heat island: spatial and temporal variability in temperature. Freshw Sci 32:309-326

Suhonen J, Korkeamäki E, Salmela J, Kuitunen M (2014) Risk of local extinction of Odonata freshwater habitat generalists and specialists. Conserv Biol 28:783-789

Sullivan MS, Gilbert F, Rotheray G, Croasdale S, Jones M (2000) Comparative analyses of correlates of Red data book status: a case study using European hoverflies. Anim Conserv 3:91-95

Stefani V, Del-Claro K (2015) The effects of forest fragmentation on the population ecology and natural history of a funnel-web spider. J Nat Hist 49:211-231

Stevens VM, Pavoine S, Baguette M (2010) Variation within and between closely related species uncovers high intra-specific variability in dispersal. PLoS One 5: e11123 
Swaegers J, Janssens SB, Ferreira S, Watts PC, Mergeay J, McPeek MA, Stoks R (2014) Ecological and evolutionary drivers of range size in Coenagrion damselflies. J Evol Biol 27:2386-2395

Takami Y, Koshio C, Ishii M, Fujii H, Hidaka T, Shimizu I (2004) Genetic diversity and structure of urban populations of Pieris butterflies assessed using amplified fragment length polymorphism. Mol Ecol 13:245-258

Ter Braak CJF (1986) Canonical Correspondence Analysis: A New Eigenvector Technique for Multivariate Direct Gradient Analysis. Ecology 67:1167-1179

Thompson B, McLachlan S (2007) The effects of urbanization on ant communities and myrmecochory in Manitoba, Canada. Urban Ecosyst 10:43-52

Trammell TLE, Carreiro MM (2011) Vegetation composition and structure of woody plant communities along urban interstate corridors in Louisville, KY, USA. Urban Ecosyst 14:501-524

Troast D, Suhling F, Jinguji H, Sahlén G, Ware J (2016) A global population genetic study of Pantala flavescens. PloS One 11: e0148949

United Nations Population Division (2015) World Urbanization Prospects: The 2014 Revision (United Nations, New York)

Unfried TM, Hauser L, Marzluff JM (2013) Effects of urbanization on Song Sparrow (Melospiza melodia) population connectivity. Conserv Genet 14:41-53

Urban MC, Skelly DK, Burchsted D, Price W, Lowry S (2006) Stream communities across a rural-urban landscape gradient. Divers Distrib 12:337-350

US Bureau of the Census (2013) QuickFacts: Jefferson County, Kentucky. Available at: http://www.census.gov/quickfacts/table/AFN120212/21111

Vale TR, Vale GR (1976) Suburban bird populations in west-central California. J Biogeogr 3:157-165

Vanbergen AJ (2013) Threats to an ecosystem service: pressure on pollinators. Front Ecol Environ 11:251-259

Vandergast AG, Lewallen EA, Deas J, Bohonak AJ, Weissman DB, Fisher RN (2009) Loss of genetic connectivity and diversity in urban microreserves in a southern California endemic Jerusalem cricket (Orthoptera: Stenopelmatidae: Stenopelmatus n. sp. "santa monica"). J Insect Conserv 13:329-345 
Van Nuland ME, Whitlow WL (2014) Temporal effects on biodiversity and composition of arthropod communities along an urban-rural gradient. Urban Ecosyst 17:10471060

Venables W, Ripley B (2002) Modern Applied Statistics Using S. 4th edn. Springer, New York

Verbeylen G, De Bruyn L, Adriaensen F, Matthysen E (2003) Does matrix resistance influence Red squirrel (Sciurus vulgaris L. 1758) distribution in an urban landscape? Landscape Ecol. 18:791-805

Vergnes A, Le Viol I, Clergeau P (2012) Green corridors in urban landscapes affect the arthropod communities of domestic gardens. Biol Conserv 14:171-178

Villalobos-Jiménez G, Dunn AM, Hassall C (2016) Dragonflies and damselflies (Odonata) in urban ecosystems: a review. Eur J Entomol 113:217-232

Walsh CJ, Roy AH, Feminella JW, Cottingham PD, Groffman PM, Morgan RP (2005) The urban stream syndrome: current knowledge and the search for a cure. J N Am Benthol Soc 24:706-723

Watkinson AR, Sutherland WJ (1995) Sources, sinks and pseudo-sinks. J Anim Ecol 64:126-130

Watson DM (2003) The 'standardized search': an improved way to conduct bird surveys. Aurstal Ecol 28:515-525

Watts PC, Rouquette JR, Saccheri J, Kemp SJ, Thompson DJ (2004) Molecular and ecological evidence for small-scale isolation by distance in an endangered damselfly, Coenagrion mercuriale. Mol Ecol 13:2931-2945

Webb JK, Brook BW, Shine R (2002) What makes a species vulnerable to extinction? Comparative life-history traits of two sympatric snakes. Ecol Res 17:59-67

Weller B, Ganzhorn JU (2004) Carabid beetle community composition, body size, and fluctuating asymmetry along an urban-rural gradient. Basic Appl Ecol 5:193-201

Westfall MJ, May ML (1996) Damselflies of North America. Scientific Publishers, Gainesville

Wickham H (2011) The split-apply-combine strategy for data analysis. J Stat Softw 40:129

Wilcox BA, Murphy DD (1985) Conservation strategy: the effects of fragmentation on extinction. Amer Nat 125: 879-887 
Willigalla C, Fartmann T (2012) Patterns in the diversity of dragonflies (Odonata) in cities across Central Europe. Eur J Entomol 109:235-245

Wilson GA, Rannala B (2003) Bayesian inference of recent migration rates using multilocus genotypes. Genetics 163:1177-1191

Wright S (1943) Isolation by distance. Genetics 28:114-138

Yater GH (2001) Louisville: a historical overview. In: Kleber JE (ed) The Encyclopedia of Louisville, 1st edn. University of Kentucky Press, Lexington, pp xv-xxxi

Zonneveld CT, Longcore T, Mulder C (2003) Optimal schemes to detect the presence of insect species. Conserv Biol 17:476-487 
CURRICULUM VITA

\author{
Victoria A. Prescott \\ 2113 Speed Ave Apt 9, Louisville, KY 40205 \\ 661-703-8471 \\ victoria.prescott@louisville.edu
}

\title{
Education
}

Doctoral Candidate-Biology PhD program

University of Louisville, Louisville, Kentucky

Anticipated Graduation Date: December 2016

Bachelor of Science in Biology, concentration: ecology

Baylor University, Waco, Texas

Graduation Date: May 2011

Baylor University Dean's List

\section{RESEARCH EXPERIENCE}

\section{University of Louisville}

\section{5-Present: Correlating species attributes with extinction risk}

- Assembled information on three attributes of rarity for a single taxon

- Compiled data from resources databases such as NatureServe and International Union for Conservation of Nature

- Composed and managed extensive spreadsheets

2013-Present: Conducted investigation of how habitat loss affects odonate diversity

- Maintained compliance of permits with local and state governments

- Surveyed dragonflies at lentic and lotic water bodies

- Obtained water quality data using data sonde

- Conducted field surveys for over 8 hours each day throughout summer months

- Performed timed linear transects while visually identifying odonates

- Implemented novel odonate field survey technique

- Transported field equipment over rough terrain

- Quantified extent of perching and oviposition sites 
- Communicated regularly with property owners

- Maintained highly organized data sheets

- Used ArcGIS software to quantify extent of urban land use surrounding around each site

- Analyzed data using R

- Identified which environmental factors affect odonate communities

\section{3-Present: Examining how loss of habitat connectivity affects spider dispersal}

- Applied for permits with local and state governments

- Conducted nightly sampling of spiders

- Assessed genetic diversity among populations

- Quantified landscape resistance to dispersal using ArcGIS software and R

- Identified specific barriers to dispersal within the landscape

- Determined location and quality of wildlife corridors within the landscape

- Identified the most important corridors and core habitat areas for maintaining connectivity

- Discovered significant isolation-by-resistance among populations

\section{Baylor University}

\section{9: Determined differential responses of odonate taxa to environmental stress}

- Participated in summer research fellowship

- Collected individuals at Lake Waco Wetlands

- Measured odonate wing areas and performed wing cell counts using Adobe Photoshop

- Analyzed levels of fluctuating asymmetry with Microsoft Excel

\section{PRESENTATIONS}

- Prescott, V.A., P.K. Eason. April 2016. Determinants of odonate diversity in ponds versus streams across an urban-rural gradient. Invited talk at Biology Department Awards Day, University of Louisville.

- Prescott, V.A, P.K. Eason. April 2016. Urbanization negatively affects dragonfly communities. Graduate Student Council Regional Conference.

- Prescott, V.A., P.K. Eason. November 2015. Dragonflies of pond and stream communities respond similarly to urbanization. Kentucky Academy of Science.

- Prescott, V.A., P.K. Eason. March, 2015. Pond and stream dragonfly communities respond differently to urban development. Midwest Ecology and Evolution Conference.

- Prescott, V.A., P.K. Eason. November, 2014. Odonate diversity across an urbanrural gradient: Odonates in ponds and streams respond differently to altered habitats. Kentucky Academy of Science.

- Prescott, V.A, D. Vodopich. August, 2009. Fluctuating asymmetry in damselflies of the Lake Waco Wetlands. Baylor University. 


\section{GRANTS RECEIVED}

2015

- Effect of habitat destruction on odonate diversity

- Horner Wildlife Refuge Grant (\$1000)

- Biology Graduate Student Association (\$300)

2012-2014

- Effect of inhospitable matrix on wolf spider dispersal

- Graduate Student Creative Activities Fund (\$500)

- Graduate Student Committee Research Fund (\$300)

- Graduate Student Committee Research Fund (\$100)

- Cornett Entomological Endowment Fund (\$2000)

\section{LEADERSHIP}

2014-Present

- Senior Graduate Teaching Assistant

- Taught laboratories for introductory biology to majors and nonmajors

- Designed new lecture powerpoints used in all lab sections

- Drafted homework assignments used in all lab sections

- Mentor undergraduate teaching assistants

- Corresponded with other teaching assistants on behalf of professor

- Communicated clearly to students

- Managed labs

- Wrote and graded exams

- Prepared equipment for laboratory experiments

- Attended weekly meetings

- Proctor exams

2011-Present

- Member, Biology Graduate Student Association

2015

- Guest Lecturer, Principles of Ecology

2015

- Third place, Oral presentation competition, Kentucky Academy of Science Conference

2014-2015

- President, Biology Graduate Student Association

- Streamlined monthly meetings

- Liaison between members and other associations

- Coordinated fundraising events

- Modified amendments and regulations of the association 
- Established new role entitled outreach coordinator

2014

- Judged undergraduate poster presentations at Kentucky Academy of Science conference

2013

- Guest Lecturer, Invertebrate Zoology

\section{COMMUNITY INVOLVEMENT}

2016

- Park Steward for Olmsted Parks Conservancy

- Volunteer management

- Community engagement

- Pesticide management

- Horticultural techniques

- Working with The Nature Conservancy to assess habitat needs of an endangered moth

- Entomologist for Lincoln Boyhood National Memorial Park BioBlitz

- Invited talk for the Sierra Club

- Invited talk for the Kentucky Society of Natural History

- Led nature walk for the Kentucky Society of Natural History

2014-2015

- Led nature walks for Kentucky Natural History Society

- Taught dragonfly biology to the public at Otter Creek Recreation Area and Blackacre State Nature Preserve

2014

- Hosted odonate booth at Bernheim Research Forest annual BugFest 